\title{
Engineering Serendipity: The Role of Cognitive Similarity in Knowledge Sharing and Knowledge Production
}

\section{Citation}

Lane, Jacqueline N., Ina Ganguli, Patrick Gaule, Eva C. Guinan, and Karim R. Lakhani.

"Engineering Serendipity: The Role of Cognitive Similarity in Knowledge Sharing and Knowledge Production." Harvard Business School Working Paper, No. 20-058, November 2019.

\section{Permanent link}

http://nrs.harvard.edu/urn-3:HUL.InstRepos:41946105

\section{Terms of Use}

This article was downloaded from Harvard University's DASH repository, and is made available under the terms and conditions applicable to Other Posted Material, as set forth at http:// nrs.harvard.edu/urn-3:HUL.InstRepos:dash.current.terms-of-use\#LAA

\section{Share Your Story}

The Harvard community has made this article openly available.

Please share how this access benefits you. Submit a story.

Accessibility 


\section{Engineering Serendipity: The Role of Cognitive Similarity in Knowledge Sharing and Knowledge Production}

Jacqueline N. Lane

Ina Ganguli

Patrick Gaule

Eva C. Guinan

Karim R. Lakhani

Working Paper 20-058 


\section{Engineering Serendipity:}

The Role of Cognitive Similarity in Knowledge Sharing and Knowledge Production

Jacqueline N. Lane

Harvard Business School

Ina Ganguli

University of Massachusetts Amherst

Patrick Gaule

University of Bath

\author{
Eva C. Guinan \\ Harvard University
}

Karim R. Lakhani

Harvard Business School

Working Paper 20-058

Copyright @ 2019 by Jacqueline N. Lane, Ina Ganguli, Patrick Gaule, Eva C. Guinan, and Karim R. Lakhani.

Working papers are in draft form. This working paper is distributed for purposes of comment and discussion only. It may not be reproduced without permission of the copyright holder. Copies of working papers are available from the author.

Funding for this research was provided in part by Harvard Business School. 


\title{
Engineering Serendipity:
}

\section{The Role of Cognitive Similarity in Knowledge Sharing and Knowledge Production}

\author{
Jacqueline N. Lane ${ }^{1,2}$, Ina Ganguli ${ }^{3}$, Patrick Gaule ${ }^{4}$, Eva C. Guinan ${ }^{1,5}$ \& Karim R. Lakhani ${ }^{1,2,6}$ \\ ${ }^{1}$ Laboratory for Innovation Science, ${ }^{2}$ Harvard Business School, ${ }^{3}$ University of Massachusetts Amherst, \\ ${ }^{4}$ University of Bath, ${ }^{5}$ Dana-Farber Cancer Institute, ${ }^{6}$ National Bureau of Economic Research
}

\begin{abstract}
We consider how the cognitive similarity between knowledge-sharing partners affects the knowledgeproduction process, namely knowledge transfer, creation, and diffusion. We theorize that knowledge production is systematically shaped by the field and intellectual similarity between knowledge-sharing partners' disciplines of study and domain area interests. To estimate relationships, we designed and executed a natural field experiment at a medical symposium, in which exogenous variation was introduced to provide some of the 15,817 scientist pairs with opportunities for serendipitous, face-to-face encounters. Our data include direct observations of interaction patterns collected using sociometric badges, and detailed longitudinal data on the scientists' publication records for six years following the symposium. We find both cooperative and competitive effects of cognitive similarity on knowledge production. While knowledge sharing increases the transfer of scientific concepts between scientists with some intellectual overlap, it reduces the diffusion of scientific knowledge between scientists from the same field. In contrast, cognitive similarity does not have a direct effect on knowledge creation, but we find that scientists who have initiated early-stage collaborations with one another are more likely to persist and publish together. The findings suggest that some cognitive similarity between knowledge-sharing partners can boost organizational knowledge production, but too much similarity may impede it.
\end{abstract}




\section{INTRODUCTION}

In 2005, Robert Havekes, a graduate student in neuroscience, and Peter Meerlo, a postdoctoral fellow researching sleep, encountered each other by chance at their department's coffee machine. Over coffee, the two budding scientists discussed how they could bring their complementary research interests together. Since that day, both researchers have gone on to become professors and directors of their own labs. Their serendipitous encounter has led to a productive research collaboration, with 15 joint publications resulting in roughly 650 citations. $^{1}$

In a different type of encounter in 2013, cell biologist William Earnshaw from the University of Edinburgh happened to attend the same academic conference as systems biologist Job Dekker from the University of Massachusetts Medical School and computational biologist Leonid Mirny from the Massachusetts Institute of Technology. After Earnshaw serendipitously attended a talk in which Dekker and Mirny presented their joint work on mitotic chromosomes, he became convinced that his lab could provide bench methods to improve Dekker and Mirny's computational models. Earnshaw approached the two collaborators after the talk; their conversation evolved into a three-lab collaboration and a 2018 publication in Science (Pain, 2018).

These anecdotal cases suggest that serendipitous encounters may have a role to play in innovation as they expose individuals to new sources of information that can be combined with their own current stock and lead to new discoveries and the generation of new knowledge (Hansen, 1999; Nagle and Teodoridis, 2019; Uzzi et al., 2013). However, most serendipitous encounters probably do not lead to the types of collaboration outcomes highlighted above. Knowledge creation through new collaborations can be a costly endeavor (Reagans and McEvily, 2003), requiring significant coordination of effort, alignment of incentives, establishment of trust, generation of creative synergy, and a set of "matching" criteria that include personality compatibility, schedule alignment, and informal relational contracting (Azoulay, Liu, and Stuart, 2009; Storper and Venables, 2004; Catalini, 2017; Mairesse and Turner, 2005).

\footnotetext{
${ }^{1}$ Citation count is derived from their joint publications on Google Scholar as of September 23, 2019.
} 
More than potentially forming a new collaborative relationship, serendipitous or "chance" encounters provide individuals with non-routine opportunities for face-to-face interaction and rich knowledge sharing (Haas and Hansen, 2007). This may enable them to learn, integrate, and apply the newly found information (to the focal individual) in their own attempts to create new knowledge (Cohen and Levinthal, 1990; Crescenzi, Nathan, and Rodriguez-Pose, 2016; Kabo et al., 2014). Knowledge sharing can aid the communication and transfer of complex knowledge that is generally multi-faceted, tacit, and embedded (Nelson and Winter, 1982; Polanyi, 1966; Szulanski, 1996; von Hippel, 1994). This type of knowledge tends to be hard to articulate and is acquired through experience (Polanyi, 1966), but personal, face-to-face interaction may improve the transfer of fine-grained information (Haas and Hansen, 2007; Uzzi, 1997).

In this paper, we seek to investigate whether a systematic relationship exists between opportunities for serendipitous knowledge sharing and knowledge production. The knowledge-production process is in itself a function of three distinct components — transfer, creation, and diffusion (Powell and Snellman, 2004; Grant, 1996; Phelps, Hiedl, and Radhwa, 2012)—and individual ability to effectively and efficiently conduct these activities will impact their performance (Galunic and Rodan, 1998; Nahapiet and Ghoshal, 1998). Yet despite the potential for serendipitous knowledge sharing to enhance knowledge production, there are also many encounters where knowledge sharing between organizational individuals has failed to produce useful knowledge (e.g., Haas and Hansen, 2005; Hansen, 1999; Inkpen and Dinur, 1998). Prior research has highlighted the salience of pre-existing ties and networks in the knowledge-production process (see Phelps, Hiedl, and Radhwa, 2012 for a review), but has also asserted that access to non-redundant sources of knowledge may provide an edge to individuals tasked with creating new knowledge (Burt, 2009). Because serendipitous encounters foster new ties, related prior work on how the strength of ties (Granovetter, 1973) and the structure of relationships in a network affect the knowledge-production process (e.g., Fleming, Mingo, and Chen, 2007; Obstfeld, 2005) does not adequately account for why serendipitous encounters can produce useful knowledge in some cases but not in others. 
We argue that an effective, non-redundant encounter hinges not just on the serendipity of the interaction but also on the individuals' ability to make sense of it and connect it to what they already know. One of the most important ways that people learn is by associating new ideas with what they already know (Bower and Hilgard, 1981; Ellis, 1965). Extant scholarship suggests that prior knowledge enhances the ability for new knowledge to be assimilated and used because of the self-reinforcing aspect of memory development (Bower and Hilgard, 1981). Based on this view, an individual's learning is greatest when the new knowledge to be assimilated is related to the concepts, objects, and patterns they have already accumulated in their existing cognitive structures (Bower and Hilgard, 1981; Cohen and Levinthal, 1990). Thus, when new information is related to their prior knowledge constructs, it is more readily absorbed, integrated, and applied in new settings (Carlile 2004; Kogut and Zander, 1996); without sufficient prior knowledge, individuals may have difficulty making sense of new knowledge (Bunderson and Sutcliffe, 2002; Lindsay and Norman, 1977). In accordance with this view, serendipitous knowledge sharing between two individuals tends to be more effective when they share some overlap in their existing cognitive structures (Dahlander and McFarland, 2013) or have some degree of cognitive similarity.

To draw causal inferences between serendipitous knowledge sharing and the knowledgeproduction process, we designed and executed a natural field experiment to facilitate knowledge sharing between "randomized" pairs of individuals. We then combined this with a rich longitudinal dataset on longrun knowledge-production outcomes. We chose an academic medical center and its affiliated researchers as the focal context of our research due to the centrality of knowledge production to their organizational and individual performance goals and the prevalence of knowledge-sharing norms within that environment (Dahlander and McFarland, 2013; Hardy, Phillips, and Lawrence, 2003; Weingart, 2000).

The field experiment took place in early 2012 at a research symposium on advanced biomedical imaging. We "engineered" exogenous variation in opportunities for information-rich, face-to-face encounters between cross-disciplinary scientists (clinical specialists of all different types, physicists, engineers, and other natural scientists) interested in applying for an internal grant program promoting the development of advanced imaging solutions to address an unmet clinical need. Using electronic sociometric 
badges (Kim et al. 2012), we collected a unique dataset of fine-grained, live interactions between pairs of scientists who were randomly assigned to be in the same knowledge-sharing symposium room. We then tracked the knowledge-production outcomes of the scientists in our study longitudinally over a six-year period, from 2013 to 2018, to directly compare the likelihood of knowledge production. This design enabled us to causally and systematically identify the relationships between knowledge sharing and knowledge production to explain why some of the serendipitous encounters resulted in knowledge transfer, creation, and diffusion and others did not.

We found both cooperative and competitive effects of cognitive similarity on knowledge production. While knowledge sharing increased the transfer of scientific concepts between scientists with some intellectual overlap, it also reduced the diffusion of scientific knowledge between scientists from the same field. In the post-symposium period, we found that knowledge transfer-proxied using the transfer of Medical Subject Heading (MeSH) keywords between knowledge-sharing partners-was most likely to occur between scientists who already had some MeSH keywords in common. Scientists from the same field were less likely to cite and diffuse each other's knowledge if they had interacted during the symposium. In contrast, cognitive similarity did not have a direct effect on knowledge creation, but we found that scientists who initiated early-stage collaborations with each other on the advanced biomedical imaging grant were more likely to persist and publish together.

We contribute to the literature on knowledge sharing and knowledge production in three ways. First, our research emphasizes the primary role of cognitive similarity in knowledge production and identifies two separate dimensions of cognitive similarity—namely field and intellectual similarities—-that affect the likelihood that knowledge sharing facilitates knowledge production. Second, we shift the focus away from the relative advantages of strong and weak ties and knowledge production by attending to a third type of tie: "new" ties. These can simultaneously facilitate access to novel resources and information (a strength of weak ties argument) and foster knowledge sharing and production (a strength of strong ties argument) under certain “engineered” or structured conditions. Third, and most importantly, we advance the knowledge frontier on how knowledge sharing affects multiple components of knowledge production 
in the long run. We do so by showing that knowledge sharing can have varied, countervailing effects on different components of the knowledge-production process, and that research that considers one part of the knowledge-production process may not provide a complete picture. To advance understanding, we combined multiple sources of data, including a natural field experiment, with detailed archival data on publication records and direct observations on knowledge-sharing interactions. While we acknowledge that these complex sources of data are difficult to come by, we show that large theoretical and empirical gains are made possible through long-term studies that coalesce multiple forms and uses of data.

The rest of the paper is organized as follows. Section 2 reviews the literature and generates hypotheses on how cognitive similarity and serendipitous encounters affect knowledge-production outcomes. Next, Section 3 reviews our methods with details of our experimental design, the data we collected, and our estimation approach. Section 4 provides our results and Section 5 provides a discussion of the theoretical and empirical contributions of this research to knowledge sharing and knowledge production. Finally, Section 6 concludes our paper with limitations and avenues for future research.

\section{THEORY AND HYPOTHESES}

Knowledge sharing is essentially a cognitive act between individuals. In its most abstract instantiation between a pair of individuals, one person will act as the sender and the other will be the receiver of information. Of course, these roles will switch repeatedly between the pair during any one interaction, and the acts of sending and receiving information will be endogenously orchestrated. The processing and impact of the knowledge being shared between individuals will be a function of the similarity of their cognition, i.e. the existence of some degree of common knowledge between them. Common knowledge is important because it enables individuals to absorb the aspects of their knowledge sets that they do not hold in common, or that are unique to each individual (Grant, 1996). In this section, we unpack the notion of cognitive similarity and hypothesize the impact it may have on the knowledge-production process.

\subsection{Two Cognitive Bases of Similarity: Field Specialty and Intellectual Specialty}


In analyzing the relationships between knowledge sharing and the knowledge-production process, we consider how the prior cognitive similarity between scientists impacts their ability to transfer, create, and diffuse knowledge. Cognitive similarity enables knowledge-sharing partners to communicate and interact effectively because shared interpretations and orientations make it easier to comprehend and learn from each other (Maurer and Ebers, 2006), and to exchange and generate knowledge together (Boland and Tenkasi, 1995). We posit that there are two separate pathways through which individuals develop their cognitive knowledge bases. These two pathways arise from an individual's field or discipline of study and their intellectual knowledge domain areas of interest. We refer to these separate dimensions as an organizational individual's field specialty and intellectual specialty, respectively. When two individuals engage in serendipitous knowledge sharing with each other, their respective field and intellectual specialties form the two cognitive bases of shared knowledge overlap, namely field similarity and intellectual similarity.

An individual's field and intellectual specialties form two separate dimensions of their prior knowledge. For example, in biomedical research, which is our focal context of study, a natural distinguishing feature between field and intellectual specialties is the difference between clinical specialties and research specialties. According to the American Board of Medical Specialties (ABMS), internal medicine has 24 clinical specialties and subspecialties, such as neurology, oncology, radiology, pediatrics, ophthalmology, and surgery (Landefeld, 2016; American Board of Medical Specialties, 2018). For each of these, medical students undergo extensive training and exams to receive a doctorate in medicine and further specialize in their selected clinical specialty during residency and fellowship training (Thompson, 2014). On the other hand, intellectual specialties are not tied to particular clinical specialties but to the broader pursuit of expertise in medical domain areas. These may include, but are not limited to, development, aging, sleep, quality of life, health economics, or translational medicine.

Field and intellectual specialties are not only important sources of organizational expertise but also serve as potential sources of social influence over the membership in the group (Haas and Park, 2010; Tajfel, 1979). Individuals that hold membership in the same field or intellectual specialties constitute a 
potential professional reference group of more similar colleagues (Haas and Park, 2010). That is, being in the same field or having the same intellectual specialties creates a shared professional characteristic that differentiates members from non-members (Hogg, 2000; Tajfel, 1979). People not only tend to view others more favorably if they share the same perceived (professional) characteristic but they also tend to prefer affiliating with others who are similar to them (Mollica, Gray and Trevino, 2003). However, although individuals can derive a sense of identity or affiliation from both field and intellectual specialties, they are distinct knowledge categories and sources of organizational expertise.

To provide a concrete example, take the clinical specialty of neurology — the branch of medicine concerned with the structure, function, and diseases of the nervous system—and the research specialty of sleep disorders, which aims to better understand the relationship between sleep and cognition in health and disease. Both specialties—neurology and sleep disorders—provide a basis of common membership: two neurologists undergo similar education, training, and examinations to become board certified; two sleep disorder researchers share a general domain interest in sleep medicine, making them more likely to hold similar memberships in medical research societies and consortia. Although it is possible that two neurologists may research sleep disorders, or that two sleep disorder researchers may be neurologists, therefore sharing the same field and intellectual specialties, the two forms of professional expertise are not always identical. That is, a neurologist and a psychologist can both study sleep disorders, or two neurologists may conduct medical research on topics unrelated to sleep disorders. Thus, neurology and sleep disorders correspond to two separate dimensions of professional expertise and it is possible for two individuals to share cognitive similarity in neither, one, or both of these dimensions.

Other professions also have similar delineations between field and intellectual specialties. In business schools, scholars choose to specialize in fields, such as accounting, finance, marketing, organizational behavior, strategy, economics, psychology, networks, and operations management. Graduate students undergo coursework and training to obtain a doctorate degree in their selected field specialty (e.g., a Ph.D. in organizational behavior). Like medicine, these field specialties are clearly distinguishable from intellectual specialties, which are based on a scholar's interests in knowledge domain areas. Examples of 
intellectual specialties include topics such as leadership, entrepreneurship, diversity, innovation, corporate governance, emotion, and social influence.

A similar distinction exists between field and intellectual specialties in business research. For example, take two organizational behavior scholars who have undergone similar education and training by taking similar coursework and examinations to receive doctorates in organizational behavior, and two scholars who may have undergone different education and training but share research interests in entrepreneurship. While it is possible that both organizational behavior scholars research entrepreneurship, it is also likely that two organizational behavior scholars may research different topics, and that a strategy scholar and a finance scholar may both research entrepreneurship. Although the organizational behavior scholars may have different research domain interests, they likely share similar kinds of research questions, draw on similar theories, utilize similar methodological toolkits, and hold similar incentives to publish in specific journals due to their requirements for tenure and promotion. On the other hand, although a strategy scholar and a finance scholar may share a research domain interest in entrepreneurship, they are likely to draw upon different research questions, theories, and methodological tools, and hold different incentives to publish in strategy and finance journals, respectively. In other words, sharing a field similarity in organizational behavior and an intellectual similarity in entrepreneurship are two distinct dimensions of cognitive similarity that may but do not necessarily overlap for a given pair of individuals.

We now develop our theory and hypotheses by considering the effects of field and intellectual similarity on the relationships between serendipitous knowledge sharing and knowledge transfer, creation, and diffusion.

\subsection{Knowledge Transfer and Cognitive Similarity}

Knowledge transfer involves the movement of facts, relationships, and insights from one setting to another. It becomes evident when the experience that was acquired by an individual, group, or organization is recreated and applied in another setting (Argote, McEvily, and Reagans, 2003; Szulanski, 1996). Knowledge transfer is a two-sided process because it depends on the efforts of a source to share knowledge 
with a recipient and the recipient's efforts and capacity to acquire, absorb, and learn it (Argote and Ingram, 2000).

People tend to find it easier to both recognize and absorb new ideas when they already have some existing expertise and more difficult when it is outside their immediate realm of expertise (Cohen and Levinthal, 1990; Reagans and McEvily, 2003), thereby suggesting that knowledge transfer is dependent on the degree of cognitive similarity between two parties. Because of this, local knowledge found within groups of cognitively similar individuals tends to be more easily transferred than distant knowledge that spans group boundaries (Carlile, 2004; Thomas-Hunt, Ogden, and Neale, 2003; Kogut and Zander, 1992; Rosenkopf and Almeida, 2003).

However, it has also been suggested that knowledge tends to be more novel and valuable when it is distant (Gavetti and Levinthal, 2000; Jeppesen and Lakhani, 2010; March, 1991; Wang, Veugelers, and Stephan, 2017), boundary-spanning (Reagans and McEvily, 2003), or from diverse knowledge domains (Perry-Smith and Shalley, 2014). This is because it is more likely to expose individuals to different perspectives from heterogeneous groups (Burt, 2004) and create more potential opportunities for knowledge transfer (Hansen, 1999). These opportunities can provide critical benefits, such as avoiding duplication of effort (e.g., using an existing imaging tool) or providing complementary expertise to solve a problem (Teece, 1986). When individuals are cognitively close, they may have greater overlap in common knowledge but have little to learn from one another (Song, Almeida, and Wu, 2003). Thus, despite the ease of absorbing ideas locally from individuals who are highly similar, more distant knowledge may present more novel and non-redundant ideas that offer greater opportunities for learning or acquiring new concepts.

We consider how cognitive similarity, with regard to field and intellectual similarities, impacts knowledge transfer. Knowledge-sharing partners from the same field specialty have similar education and training. Thus, ideas that are shared between scientists from the same field specialties are more readily absorbed. At the same time, these ideas are also more likely to be redundant and less likely to represent new concepts or insights. For instance, two neurologists who have gone through the same training, examinations, certifications, and continuing education courses have similar formal expertise and are 
unlikely to share knowledge that is atypical or novel. By contrast, while a neurologist and a neuropsychiatrist share some cognitive similarity, based on their expertise in diseases of the nervous system, they also hold differentiated knowledge because they focus on different types of nervous-systembased diseases. In the same vein, a neurologist and a cardiologist may also benefit from a greater potential pool of novel ideas. Accordingly, we would expect that serendipitous knowledge sharing between individuals from different field specialties would give rise to a greater potential pool of ideas and concepts for knowledge transfer (Argote, 1999; Brown and Duguid, 1991; Larson Jr. and Christensen, 1993). Based on these arguments, we hypothesize that knowledge sharing provides more opportunities for knowledge transfer among scientists from different field specialties because of the potential to learn non-redundant knowledge that can be acquired and absorbed into their existing knowledge repositories.

H1a. Knowledge sharing is more likely to lead to knowledge transfer when individuals span different field specialties.

Likewise, the degree of intellectual similarity between knowledge-sharing partners tends to shape their capacity for knowledge transfer. The opportunities for knowledge transfer are likely to increase as the degree of intellectual similarity decreases. There is a wider pool of knowledge to draw upon, which allows for multiple perspectives and problem-solving approaches and increases the likelihood of novel solutions and discoveries. However, beyond a certain threshold, individuals become so intellectually dissimilar that they no longer share sufficient prior related knowledge to utilize these opportunities. That is, the communication and coordination costs associated with knowledge sharing begin to outweigh the potential benefits of knowledge transfer. At the other extreme, when there is too much intellectual similarity between knowledge-sharing partners, this decreases the stock of opportunities from which they can benefit since they only perceive a narrow (myopic) spectrum of the paths available and hold similar views (ThomasHunt, Ogden, and Neale 2003; Janis, 1972). These contrasting arguments suggest there may be a trade-off between intellectual similarity and the opportunities available for knowledge transfer. When individuals have too little or too much intellectual similarity, there is a relatively smaller pool of transferable knowledge 
compared to a moderate degree of intellectual similarity. We therefore expect that intellectual similarity has an inverted U-shape effect on the relationship between knowledge sharing and knowledge transfer.

H1b. Intellectual similarity has an inverted U-shaped effect on the relationship between knowledge sharing and knowledge transfer.

\subsection{Knowledge Creation and Cognitive Similarity}

Knowledge creation refers to the generation of facts, relationships, and insights to solve problems that are new to the existing knowledge frontier (Arrow, 1962; Boudreau and Lakhani, 2015; Nonaka, 1994). Because new knowledge is not held by anyone prior to its creation, it cannot be transferred and applied directly (McFadyen and Canella, 2004). The emphasis on new knowledge is what distinguishes the process of knowledge transfer from creation. Much work shows that knowledge creation is a social process (Amabile, 1993; Perry-Smith and Shalley, 2003; Uzzi and Spiro, 2005). Although ideas are formed within the minds of individuals, interaction between individuals is also critical to developing these ideas into new knowledge (Nonaka, 1994; Simon, 1991). The trend towards joint knowledge creation has been prevalent across many fields, spanning creative industries (Uzzi and Spiro, 2005), patented inventions (Singh and Fleming, 2010), international joint ventures (Inkpen and Dinur, 1998), new product development (Smith, Collins, and Clark, 2005), and research scientists (McFadyen, Semadeni, and Cannella Jr., 2009). Moreover, Jones (2009) puts forth the "knowledge burden” hypothesis, which creates an increased need for collaborative work that combines the increasingly narrow niches of specialization to move the knowledge frontier forward.

Turning to knowledge creation in science, scientific discovery is a process that combines individually focused tasks—such as reading, experimentation, and writing —with social interactions through joint sense-making with others (Latour and Woolgar, 1979). Thus, while publication demarcates what is already known on the knowledge frontier from what remains to be explored (Boudreau and Lakhani, 2015), reading and transferring codified knowledge is generally not sufficient for new knowledge creation (Cockburn and Henderson, 1998). The growing trend of teams in science supports this argument (Wuchty, Jones and Uzzi, 2007), as collaborations that foster the integration of skills, ideas, and experiences across 
individuals contribute to a broader and more thorough search process (Page, 2007) and can spark novel recombinations that aid the discovery of new knowledge (Boudreau et al., 2016; Fleming, 2001; Schumpeter, 1934; Usher, 1954; Uzzi et al., 2013; Wang, Veugelers, and Stephan, 2017).

Building on this argument, serendipitous knowledge sharing may enable one form of knowledge creation by providing opportunities for partners to form collaborations. While it may be possible for any individuals to jointly create knowledge, the types of collaboration that actually form are likely to be constrained by the degree of similarity in two individuals' cognitive structures. Hence, we now consider how field and intellectual similarities between two knowledge-sharing partners may impact their likelihood of creating knowledge together.

Although individuals may be motivated to interact with people who are unfamiliar or dissimilar to them (Song, Almeida, and $\mathrm{Wu}, 2003$ ), people tend to gravitate towards uncertainty reduction in their encounters when afforded the opportunity to interact (Ingram and Morris, 2007; Podolny, 1994). Principles of homophily suggest that people are attracted to others who hold similar values because their interactions are more rewarding and less uncertain (Lazarsfeld and Merton, 1954; McPherson, Smith-Lovin, and Cook, 2001). The degree of cognitive similarity between two knowledge-sharing partners tends to be an important basis of value homophily for scientists (Dahlander and McFarland, 2013), suggesting that the rewards from communicating with others who are more cognitively similar may outweigh the potential opportunities to secure new information from dissimilar individuals, even though they may offer greater synergies for knowledge creation (Wang, 2016).

Moreover, when evaluating potential collaborators, knowledge creation places a greater relationship burden on the given knowledge-sharing partners than knowledge transfer. Whereas knowledge transfer does not necessarily require trust, familiarity, or shared experience between the sender and recipient to facilitate knowledge sharing (Hansen, 1999), joint knowledge creation requires greater effort and an investment in a relationship, particularly if each person is required to establish a connection beyond his or her close contacts to integrate diverse but not always congruent knowledge inputs (Bunderson and Sutcliffe, 2002). Perhaps an appropriate metaphor for the decision to collaborate is the "build-or-buy" framework, 
because both parties need to assess whether the skills and resources acquired by "buying” a new collaboration outweigh the associated transaction costs (Powell, Koput, and Smith-Doerr, 1996) associated with "building” alone or with a prior collaborator.

Research collaborations are not purely instrumental or socio-emotional relationships; they are embedded relationships (McFadyen and Cannella, 2004; Uzzi, 1997) of dependence (Carlile, 2004) that require each party to consider the needs of the other to achieve their goals (Dahlander and McFarland, 2013; Morris, Podolny, and Sullivan, 2008). New collaborations require start-up costs and relationship uncertainty, which may outweigh the potential skills, fresh ideas, and creative material that a new collaborator adds during knowledge creation. Much evidence suggests that scientists may prefer working with prior collaborators (Guimera et al., 2005) because their existing relationship provides them with a great deal of information about each other (Dahlander and McFarland, 2013) that includes shared norms and behaviors (Uzzi, 1997), trust (Granovetter, 2005), and memberships in cohesive networks that sanction against unproductive, shirking behaviors (Reagans and McEvily, 2003; Uzzi, 1997).

For a new collaboration to be an attractive option, two knowledge-sharing partners need sufficient cognitive similarity to increase the chances of a serendipitous knowledge-sharing encounter resulting in knowledge creation. Hence, we expect that two knowledge-sharing partners are more likely to engage in knowledge creation together when they share the same field specialty and some intellectual similarity. When individuals share the same field specialty, the challenges of communicating and comprehending each other decrease and this increases the likelihood that they can transform a "new" relationship (i.e., an acquaintance) into a more mature one. Pairs who share a field specialty have undergone the same education and training, which provides a common basis for rewarding interactions. Moreover, individuals from the same field specialty share similar memberships of professional groups (Haas and Park, 2010), which provides two potential benefits for solidifying relationships. First, professional groups provide members with greater opportunities for subsequent encounters in shared foci, such as conferences, workshops, and continuing education courses (Catalini, 2017; Chai and Freeman, 2019). Second, members typically have similar incentives and requirements for promotion and tenure (Stephan, 1996). Thus, compared to 
individuals spanning different fields, it is easier for knowledge-sharing partners from the same field to engage in knowledge creation because their shared field specialty makes their initial encounters more rewarding and their memberships of shared foci reduce the frictions (e.g., coordination costs, lack of trust) associated with knowledge creation (Biancani, Dahlander, and McFarland, 2014). For these reasons, we expect that serendipitous knowledge sharing between individuals from the same field specialty is more likely to result in knowledge creation.

H2a. Knowledge sharing is more likely to lead to knowledge creation when individuals share the same field specialty.

Likewise, people with greater intellectual similarity are also more likely to be attracted to one another because they conduct research in similar knowledge domain areas (Dahlander and McFarland, 2013; McPherson, Smith-Lovin, and Cook, 2001). They may also share similar memberships of professional groups (Haas and Park, 2010). However, unlike field specialties—for which individuals undergo similar training, rigorous examination, and certification for their chosen discipline of studyintellectual specialties are developed based on an individual's interests in knowledge domain areas. Compared to sharing the same field specialty, these collaborations are less likely to be based solely on convenience (e.g., geographic proximity, organizational foci) and external pressures (e.g., publishing constraints, promotion criteria) and more likely to be formed on the basis of potential synergies and complementarities. For example, interdisciplinary research centers are typically formed to create new domains of collaboration among faculty and researchers with similar domain interests (Biancani, McFarland, and Dahlander, 2014). Therefore, the effects of intellectual similarity on serendipitous knowledge sharing and knowledge creation are likely to be slightly different than those of field similarity.

Although knowledge sharing tends to be more successful when scientists share some intellectual similarity, scientists benefit from knowledge specialization and differentiation from their peers (Jones, 2009). When individuals share a high degree of intellectual similarity, they have fewer opportunities for synergies and complementarities. In extreme cases, they may be substitutes for one another (Dahlander and McFarland, 2013). In other words, increasing intellectual similarity should benefit knowledge creation up 
to a threshold, over which there are decreasing marginal returns on greater levels of intellectual similarity. Therefore, we expect that intellectual similarity will have an inverted U-shaped effect on the relationship between knowledge sharing and knowledge creation.

H2b. Intellectual similarity has an inverted U-shaped effect on the relationship between knowledge sharing and knowledge creation.

Thus far, we have argued that cognitive similarity increases the likelihood that serendipitous knowledge sharing between two unfamiliar individuals leads to knowledge creation. Another pathway that may lead to joint knowledge creation is prior collaborations and tie persistence (Dahlander and McFarland, 2013). We examine a specific type of tie persistence, namely the likelihood that an elemental collaboration persists to create a complete knowledge product. In science, grant co-applications are more closely tied to the idea-generation phase (i.e., elemental collaboration), whereas co-publications are typically the final output of the implementation phase of the idea journey (i.e., complete knowledge product) (McFadyen and Cannella, 2004; Perry-Smith and Mannucci, 2017). Both grants and publications are central to a research university's prestige and a faculty member’s prospects of promotion and tenure (Dahlander and McFarland, 2013). Grant collaborators incur significant effort to co-apply for a grant, needing to overcome the search costs and frictions that often serve as barriers to finding suitable collaborators (Boudreau et al., 2017), and have gone through the process of jointly creating a core idea or concept (Perry-Smith and Mannucci, 2017). Thus, there are benefits of continued collaboration to systematically evaluate an initial idea from a grant co-application and further develop it into a potential co-publication. Taking these considerations into account, we expect that two knowledge-sharing partners are more likely to persist in knowledge creation if an elemental collaboration already exists.

Hypothesis 2c. Knowledge-sharing partners are more likely to persist in knowledge creation when the individuals share an existing elemental collaboration.

\subsection{Knowledge Diffusion and Cognitive Similarity}

Whereas knowledge transfer and creation focus on the processes through which nascent ideas are conceptualized and implemented (Perry-Smith and Mannucci, 2017), knowledge diffusion refers to the 
process through which facts, relationships, and insights are then disseminated to other individuals, groups, and organizations (Fleming, Mingo, and Chen, 2007; Singh, 2005). Knowledge diffusion is a critical component of the knowledge-production process because it reduces duplication of effort (Lakhani and von Hippel, 2003), promotes learning (Hansen and Haas, 2001), and enhances efficiency by demarcating what is already known from what remains to be explored on the knowledge frontier (Boudreau and Lakhani, 2015).

Haas and Hansen (2007) differentiate between two dimensions of knowledge-diffusion mechanisms: electronic or written documents and personal face-to-face interactions. Knowledge obtained from written or electronic documents tends to be most appropriate for knowledge that can be readily codified (Polanyi, 1966; Winter, 1987), whereas face-to-face interactions involve direct knowledge sharing between two individuals and allow for the transmission of tacit or non-codified knowledge that is hard to articulate in writing (Daft and Lengel, 1986; von Hippel, 1994). Moreover, one type of knowledge diffusion may lead to another, such as when an employee finds a useful document in the firm's knowledge repository system or on a social media platform and decides to contact the document's author (Haas and Mortensen, 2007; Treem and Leonardi, 2012), or when an employee receives advice from a colleague about a useful document (Haas and Mortensen, 2007).

We focus on the latter case-where personal face-to-face interaction between two knowledgesharing partners may result in the interactants accessing a useful written or electronic document—for two reasons. First, serendipitous knowledge sharing may motivate partners to engage in more in-depth learning of new topics and concepts (Lee, 2019), as well as individual-level exploration (Levinthal and March, 1993) of codified knowledge, such as in publications in journals, conference proceedings, webpages, listservs, and CVs. Second, information technology (IT) and the internet have brought about major changes in scientific research and contributed to increased productivity and collaboration patterns in academia (Ding et al., 2010). Therefore, electronic networks have greatly improved connectivity among scientists (Adams et al., 2005) and had a democratizing effect on scientists' ability to search and locate publication data in different fields (Ding et al., 2010). 
Turning to the effect of serendipitous knowledge sharing on knowledge diffusion, we investigate how the cognitive similarity between two knowledge-sharing partners affects the likelihood that they will cite each other in their subsequent research publications. We focus on forward citations because they constitute a critical means of social recognition for scientists to acknowledge the contributions of their predecessors (Merton, [1942] 1973) and trace the path of scientific knowledge discovery and diffusion (Stephan, 1996). Some scholars have argued that the number of citations an article or body of work has is perhaps the most common way to measure the importance of an individual's contribution to science (Stephan, 1996). According to this view, citations have been deemed a critical currency in the cycles of scientific credit (Latour and Woolgar, 1986), both driving research impact (e.g., H-index, i-10 index, impact factor) and constituting the basis of reward systems in science, including promotion, status, funding, peer esteem, honors and awards (Boudreau and Lakhani, 2015). Therefore, citations are highly valued in science because they facilitate the diffusion of knowledge and serve as the primary outlet of social recognition to publicly acknowledge a scientist's status, achievements, merits, and value.

There are generally two views of how knowledge is diffused in science, corresponding to openness and secrecy. Here, we briefly consider these two views and how cognitive similarity may affect the likelihood that serendipitous knowledge sharing between two individuals would lead to a greater rate of citations of each other's research publications. According to the Mertonian norms of communalism or “openness,” publication enables scientists to establish priority of discovery and allows them to be the first to communicate an advance in knowledge (Merton, [1942] 1973). However, publication also marks an important transition point in the diffusion process, because it means that a scientist has agreed to relinquish his or her property rights over a discovery and allow others to freely use this knowledge, as long as they give credit to their predecessors (Merton, [1942] 1973). Thus, publication promotes the open diffusion of scientific knowledge, as long as scientists trust that their internal agents—i.e., other scientists (Zuckerman, 1988)—will appropriately recognize and diffuse their work (Boudreau and Lakhani, 2015; Sztompka, 2007), most commonly with a forward citation (Stephan, 1996). 
In support of Mertonian norms of open knowledge diffusion, serendipitous knowledge sharing may lead to greater citations between two cognitively similar individuals. For instance, when knowledge-sharing partners learn new ideas and concepts that they find worthwhile to pursue in greater depth, people with greater cognitive overlap can read each other's publications and integrate these ideas into their own research with relative ease compared to scientists who are less cognitively similar and also less connected in terms of their professional group memberships. Thus, we would expect that individuals with greater cognitive similarity, with regard to field and intellectual similarities, are also more likely to acknowledge each other's valuable contributions with greater forward citations. This view is supported by much evidence in both the innovation and social network literatures, indicating that knowledge tends to diffuse more easily within homogenous groups than between heterogeneous groups that are sparsely connected (Bunderson and Sutcliffe, 2002; Catalini, 2017; Fleming, Mingo, and Chen, 2007; Hansen, 1999; Singh, 2005).

On the other hand, social recognition in science is a discretionary act on the part of the beneficiaries. In contrast to the Mertonian norms of openness, there is well-documented evidence of counter-norms in science that promote secrecy, competition, and information withholding (Haas and Park, 2010; Haeussler et al., 2014; Mitroff, 1974). This is due to the fact that scientists often compete for similar resources, funding, and recognition, which tends to create negotiated transactions for which scientists need assurance that they will be remunerated in the form of some reward for openly diffusing knowledge (Murray and O’Mahoney, 2007). Often such an egalitarian system for distributing rewards is difficult to engender because disproportionate credit and visibility are afforded to eminent scientists, rather than newcomers and less-established scientists (Merton, 1968). Given that scientists operate in highly competitive environments (Stephan, 1996), knowledge-sharing partners may not openly recognize and diffuse each other's ideas, even if they have benefited from them. For example, Hagstrom (1974) surveyed over 1,700 scientists across 35 disciplines and found that 44 percent self-reported that they had failed to properly acknowledge prior work even though they were aware of it. More recent evidence indicates that norms for secrecy and competition have only increased in science (Walsh and Hong, 2003), and that social recognition (i.e., major awards) 
granted to a focal scientist may elicit negative spillover effects on peers (Reschke, Azoulay, and Stuart, 2018).

Corroborating the findings of past research suggests that scientists do not unequivocally diffuse each other's publications using forward citations. Among scientists who are cognitively similar, serendipitous knowledge sharing may heighten the competition effect, particularly as communication and interaction may emphasize the commonalities between knowledge-sharing partners, such as their shared knowledge and experiences and their common memberships of professional groups (Hogg, 2000; Hogg et al., 2007). While these professional groups provide shared organizational foci and a collective identity (Feld, 1981; Flynn, 2005), members of the same professional groups are also competitors for priority (Merton, [1942], 1973), recognition (Campbell et al., 2002), funding, resources, and promotion requirements (Blumenthal et al., 1997). Under these competitive situations, scientists may perceive the need to differentiate themselves from other cognitively similar individuals (Brewer, 1991; Hornsey and Jetten, 2004), suggesting that social recognition would not only highlight their similarities but may also detract attention and resources away from the focal scientist's own work (Campanario and Acedo, 2007). To promote their own private interests, knowledge-sharing partners who are cognitively similar-i.e., sharing the same field specialty or sharing high intellectual similarity-may refrain from citing each other's research in an effort to outperform others (Tsai, 2002). More formally, we expect that the relationship between knowledge sharing and diffusion would be more negative for pairs sharing the same field specialty or as intellectual similarity increases.

H3a. Knowledge sharing is less likely to lead to knowledge diffusion when individuals share the same field specialty.

H3b. Knowledge sharing is less likely to lead to knowledge diffusion as the intellectual similarity between individuals increases.

Table 1 provides a summary of our hypotheses and how field and intellectual similarity impacts the likelihood that knowledge sharing leads to knowledge transfer, creation, and diffusion. 


\section{METHODS}

In an ideal setting, all of the prior interactions and efforts that go into knowledge production would be fully observable to scholars as they theorize and validate through empirical observations. The reality, however, is that the vast majority of prior scholarly work concerned with how knowledge is produced has primarily focused on observed outcomes-e.g., papers, patents, citations, team structure, etc.- to draw inferences about the mechanisms underlying the knowledge-production process (Ahuja, 2000; Benner and Tushman, 2002; Dahlander and McFarland, 2013; Fleming et al., 2007; Staw and Epstein, 2000; Powell et al., 2005; Uzzi and Spiro, 2005). For example, research on scientists will include the papers they publish, the collaborators they have worked with, and the knowledge that they have developed and have diffused through the citations.

However, a concern with relying on published trace data is that it masks all of the work and activities that occurred prior to the production of the knowledge product. We do not get to observe the risk set of collaborators they might have interacted with prior to settling on a particular team. We also do not observe the knowledge that they might have been exposed to from other individuals who are not in their authorship teams that may have influenced them or the decisions they have made to include or exclude the work of others within their own knowledge problem.

These empirical shortcomings of not being able to directly observe knowledge sharing and the drivers of knowledge production may thus insert biases in our inferences. These include unobserved differences in ability, motivation, and self-selection (e.g., homophily, geographic proximity), which can relate to individual preferences to affiliate (Cummings and Kiesler, 2008; McPherson, Smith-Lovin, and Cook, 2001), and survivor bias, such as unobserved interactions (Marsden and Campbell, 1984), prior assumptions about knowledge-sharing outcomes (Azoulay et al., 2018; Fleming, Mingo, and Chen, 2007), and difficulty in observing interactions that do not lead to knowledge production (Dahlander and McFarland, 2013).

A feasible alternative to not having access to the full suite of prior actions and considerations is to design a field experiment that enables the capture of data around interactions between scientists and 
overcomes concerns around endogeneity of affiliation, team formation, and knowledge exposure by randomizing the encounters that the scientists have with each other. The benefit of this approach is that a properly designed experimental study can provide causal explanations about the factors that impact knowledge production. The downsides of this approach include the cost and effort needed to source an appropriate field site and the challenges of drawing inferences with smaller sample sizes in an experiment as opposed to relying on all observed data of many more scientists.

In this section, we describe our experimental setting and design and then discuss the randomization approach we took to implement our field experiment.

\subsection{Experimental Setting and Design}

In our study, we used a natural field experiment for two reasons. First, experimentation enabled us to randomly assign participants into treatment and control groups to ensure that every observation had the same probability of being assigned to the treatment group and that the experimental groups had the same expected outcomes, which is a fundamental requirement for unbiased causal inference. Second, field experimentation attempts to simulate as closely as possible the conditions of a causal process, but also aims to enhance the external validity of the experimental findings (Gerber and Green, 2008). Because we were interested in how knowledge sharing impacts knowledge production in science, we chose to conduct a natural field experiment in order to unobtrusively assess the effects of realistic treatments on our subjects in a naturalistic setting (Harrison and List, 2004).

To design and conduct the natural field experiment, we collaborated with the administrators of Harvard Medical School (HMS) to layer a medical symposium onto a Harvard Clinical and Translational Science Center (Harvard Catalyst) pilot grant program. Closing the gap between research findings and clinical applications ("bench to bedside”) is a major priority for the National Institutes of Health (NIH). This has resulted in the establishment of a new institute, the National Center for Advancing Translational Sciences, which provides significant research funding to universities and hospitals that undertake collaborative translational activities to accelerate treatment development. As part of Harvard's efforts to promote clinical and translational research, the Harvard Catalyst provides seed funding in the form of pilot 
grants to support nascent research efforts. These pilot grants are awarded competitively to faculty within Harvard University. They emphasize early-stage research with the potential to improve human health. Pilot grant funding enables researchers to generate the preliminary data that are essential for applications for larger NIH grants.

This particular grant opportunity, which offered $\$ 50,000$ per award for up to 15 pilot grants, centered on proposals to devise or improve methods for using advanced biomedical imaging technologiesspecifically, physiological magnetic resonance (MR), positron emission tomography (PET), and optical imaging - to address unmet clinical needs. A major challenge in the field of advanced imaging is that progress requires both expertise in the latest imaging tools and technologies and a deep understanding of the health problems to which they could be applied, and these different types of knowledge are typically held by people with distinct disciplinary backgrounds. Thus, advanced imaging is an archetypical example of a problem often found in modern science where advancing the knowledge frontier requires combining knowledge embodied in different individuals (Jones, 2009).

We worked in close collaboration with HMS administrators and executives to redesign their pilot grant process so that we could obtain causal inferences about the role of search costs in finding collaborators. In November 2011, we invited all eligible participants to a medical research symposium for a unique grant funding opportunity centered on advanced imaging technologies using a directed e-mail campaign, outreach to departmental clinical and research directors, and marketing messages on various internal websites and through posters displayed in different facilities. Our field experiment involved faculty and researchers at Harvard University and its affiliated hospitals and institutions. Although the experiment is set entirely within a single university system, the researchers work in distinct organizations and research centers. Each hospital is independently owned and managed and appears as a separate entity in hospital rankings and lists of NIH grant recipients.

In the first stage, investigators interested in applying for the grants were asked to submit a statement of interest in which they briefly described a specific medical problem that advanced imaging techniques could potentially address. Basic biographical information (e.g., degree, institution, department 
appointment) was collected at this stage. Information distributed about the funding opportunity specified that eligibility to submit a final application was conditional on attending an advanced imaging symposium on one of three preannounced dates. Applicants could indicate at this stage if there were any dates during which they could not attend the symposium. We also communicated to applicants that the symposia would be studied by Harvard Catalyst to develop better insights about scientific team formation and that data on interaction patterns between individuals would be collected.

\subsection{Randomization and the Advanced Imaging Symposium}

The symposia were held on January 31, February 1, and February 2, 2012, at the Harvard Innovation Lab, located on Harvard's Allston campus. 402 participants were randomly assigned to one of three nights of the symposium (accounting for scheduling restrictions), one of four breakout rooms, one of two groups, and a poster location to stand next to around the perimeter of the room. This forms our complete risk set of individuals that we observed both during the experiment and then over a six-year period for longterm knowledge-production outcomes. As shown in Figure 1, each of the three nights of the symposium included five events in the same sequence and format: 1) a 30-minute introduction by the program leadership describing the pilot grant opportunity and agenda for the evening; 2) a 45-minute structured information-sharing poster session in breakout rooms; 3) a 15-minute social break where participants could mingle in a common space with refreshments and food; 4) a second 45-minute structured informationsharing poster session in the same breakout rooms; and 5) a 15-minute informal wrap-up and departure.

The 90 minutes of structured information sharing in the breakout rooms enabled us to randomly assign pairs into the same breakout rooms for knowledge sharing. We designed the process such that scientists had the opportunity to present their ideas in the form of posters and to learn about other scientists' ideas displayed on their posters or through direct knowledge sharing. Each poster followed a standard format describing each participant's submitted idea from the statement of interest (based on information they had provided prior to the event) and was placed in the breakout room in advance. The posters were intended to foster information sharing among participants and included the following details related to the statement of interest idea: (a) What is your question?; (b) Why does it matter?; and (c) What is needed for 
your research to succeed? A 300-character limit was imposed for each question. Harvard Catalyst prepared the posters to be a standard size and in a standard format, and each was placed on a separate whiteboard that allowed for the possibility of visual explanations and note-taking. Within each breakout room, scientists were randomly assigned to a poster location around the perimeter of the room and to one of two groups. Group One stood by their posters during the first 45-minute poster session while Group Two circled around the room, and the two groups switched roles during the second 45-minute poster session. As a result, our design created exogenous variation in opportunities for knowledge sharing between scientists who were assigned to the same versus different breakout rooms.

Shortly after the symposia, all participants received an e-mail invitation to submit applications for the pilot grants or concept awards by the deadline of March 8, 2012. At this time, they also received PDF booklets with the names, contact information, and posters of all researchers who participated over the three nights. The intention was to provide identical information to all participants apart from information acquired specifically in the breakout rooms at the symposia. Researchers without a faculty appointment could not be principal investigators on a pilot grant application, but they could be co-investigators on an unlimited number of applications. At least one applicant on any grant application had to have attended the symposium. The grant application did not need to be based on the initial statement of interest.

Extra care was taken to ensure that the symposium process did not somehow prime participants to seek collaborations only in their breakout rooms. Participants were informed that the composition of their teams would not be communicated to reviewers and would not be considered as a criterion for awarding the grant.

\subsection{Data and Estimation Approach}

We tested our hypotheses using data from a variety of resources from the advanced imaging symposium and the six years of publication records from 2013 to 2018 of all scientists that attended the 2012 symposium. Our setting is unique and suitable for testing our hypotheses because the breakout room interventions created exogenous variation in the information available to scientists about the other participants. Our design enables us to overcome the limitations of observational data, which often have 
endogeneity issues arising from individuals’ ability to self-select who they work with. Accordingly, we can draw causal inferences between knowledge sharing at the symposium and knowledge production, namely knowledge transfer, creation, and diffusion.

We used data from the scientists' registration form for the symposium, which contained information about their institution, department, academic position, self-identity as an imager or clinician, and statements of interest. These data were also matched against their websites on Harvard Catalyst Profiles to collect information about their office location and gender. During the symposium, participants also wore electronic devices called “sociometric badges,” which automatically recorded their face-to-face encounters (Kim et al., 2012). These badges enabled us to directly observe who interacted with whom during the symposium. Face-to-face interaction was recorded when two badges were facing each other with a direct line of sight within a 30-degree cone of $1 \mathrm{~m}$ and was verified by Bluetooth proximity data as being within 10m (Kim et al., 2012). Face-to-face interaction data was collected for 306 or 76 percent of the scientists who attended the symposium. ${ }^{2}$

After the symposium, we collected information on the co-applicants and the awardees of the advanced imaging grant. Lastly, we used the Scopus database to collect scientists’ publication records. In the event that an individual had multiple Scopus profiles, we extracted and aggregated the publication records associated with each of the Scopus matches for a particular scientist. We focused on publications because they reflect scientists' instrumental efforts in knowledge production and are an important consideration for tenure, promotion, compensation, awards, and recognition (Stephan, 1996).

\subsection{Dependent Variables}

Knowledge transfer. In the life sciences, the U.S. National Library of Medicine uses a controlled MeSH taxonomy of keywords to index articles for PubMed. Each article citation is associated with a set of MeSH keywords that describe the content of the citation. MeSH keywords are assigned not by authors but

\footnotetext{
${ }^{2}$ Badges were randomly assigned to symposium attendees but there were 94 malfunctioning badges that did not record face-to-face interaction data. Participants were not aware of whether they were assigned a working or faulty badge. In supplementary analysis not shown, we conducted OLS regressions to examine possible differences in key observable dyad-level variables between the two samples and found no significant differences.
} 
by professional science librarians and computer algorithms trained specifically to perform this task. The use of this controlled vocabulary is intended to ensure global and consistent assignment of keywords across the life sciences (Coletti and Bleich, 2001).

For our first analysis, we extracted the unique MeSH keywords associated with each scientist's publications to create two vectors of MeSH keywords: one that stored all MeSH keywords prior to the advanced imaging symposium (i.e., pre-2012), and a second that stored all MeSH keywords after the symposium (i.e., 2013-2018). We chose not to include the year 2012 to remove potential topics or ideas that were in progress prior to the symposium. For each scientist pair $\{i, j\}$, we then counted the number of MeSH terms that $j$ recombined from $i$ and the number of MeSH terms that $i$ recombined from $j$ by counting the intersection of MeSH keywords between i's pre-2012 vector and j's post-2012 vector and between $j$ 's pre-2012 vector and $i$ 's post-2012 vector, excluding any MeSH terms that were common to both $i$ and $j$ in their pre-2012 MeSH vectors. Knowledge transfer was then measured as the count of the total number of “transferred” MeSH terms between a pair $\{i, j\}$, normalized by the total number of MeSH keywords in scientists $i$ and $j$ 's post-2012 MeSH vectors, expressed as a percentage. The resulting measure ranged from 0 to 100 percent and is interpreted as the percentage of post-symposium MeSH terms that were transferred between scientist pair $\{i, j\}$, with 0 percent representing no transferred MeSH terms between the given scientist pair $\{i, j\}$ and 100 percent representing complete transfer of MeSH terms between the pair.

Knowledge creation. For our second analysis, we focused on the number of successful collaborations between scientist pair $\{i, j\}$ that resulted in publications in peer-reviewed journals, conference proceedings, and book chapters. Therefore, the knowledge creation variable is the count of co-publication ties between each pair $\{i, j\}$ from 2013 to 2018.

Knowledge diffusion. For our third analysis, we counted the number of forward citations from scientist $i$ to $j$ and from scientist $j$ to $i$ between 2013 and 2018 for publications in journals, conference proceedings, and book chapters. In science, citations are the main form of acknowledgment of prior worka scientist is expected to give credit to a predecessor's work that has impacted his or her own publication.

\subsection{Communication Variables}


Same room. To test our hypotheses, we assess how random assignment to the same breakout room impacted knowledge transfer, creation, and diffusion. Pairs that were assigned to the same breakout rooms had information-rich, structured opportunities for knowledge sharing that were not available to pairs that were assigned to different breakout rooms. We developed a dummy that measured whether scientists $i$ and $j$ are from the same or different rooms.

Face-to-face communication. We also assessed whether the given scientist pair $\{i, j\}$ interacted during the symposium to provide a more granular and fine-grained interpretation of whether scientists $i$ and $j$ had a recorded face-to-face interaction, captured using the sociometric badges. We used a dummy variable to measure whether scientists $i$ and $j$ had at least one minute of recorded interaction.

\subsection{Cognitive Similarity Variables}

Field similarity. We tested field similarity using clinical specialties, which is a salient part of a scientist's professional identity in academic medicine. Clinical specialties pertain to the "bedside” of a patient, to be founded on actual observation and treatment of patients over the course of the disease. A clinical specialty was coded from the statements of interest by third-party experts. We measured field similarity with a dummy variable indicating whether scientists $i$ and $j$ had the same or different clinical specialties. Forty clinical specialties were content coded from the statements of interest.

Intellectual similarity. We tested intellectual similarity using prior MeSH keyword overlap, which is the count of identical MeSH keywords in scientists $i$ and $j$ 's pre-2012 MeSH keyword vectors. We measured intellectual similarity with a categorical variable split into three approximately equal-sized groups, indicating whether $i$ and $j$ had low, moderate, or high MeSH keyword overlap prior to the 2012 symposium. Low intellectual similarity corresponded to 0-2 common keywords, moderate intellectual similarity corresponded to 3-11 common keywords, and high intellectual similarity corresponded to more than 11 common keywords.

\subsection{Elemental Collaboration Variable}

Grant co-applicant. We tested the persistence of an elemental collaboration using the variable grant co-applicant, which captured whether scientists $i$ and $j$ co-applied on the advanced imaging grant. 
Grant awardee. For the second set of analyses on knowledge creation, we added the variable grant awardee to examine how the persistence of an elemental collaboration (i.e., grant co-application) would be impacted by whether the scientist pair was a grant awardee. We measured grant awardee as a dummy variable that captured whether one or both scientists in the pair was a recipient of an advanced imaging pilot grant. Among the 306 subjects in the sample, thirteen pilot grant proposals were awarded funding, which corresponded to 6.54 percent of scientist pairs with at least one grant awardee.

\subsection{Control Variables}

Prior ties. Because of the investment and duration of collaboration ties in science (Dahlander and McFarland, 2013), we used three dummy variables to capture collaboration patterns between scientists $i$ and $j$ prior to, immediately after, and following the symposium: i) prior co-author captured whether scientists $i$ and $j$ had co-published research together before 2012; post co-author captured whether scientists $i$ and $j$ co-published research between 2013 and $2018 .^{3}$

Dyad-level shared characteristics. We controlled for shared characteristics between scientists $i$ and $j$ using several variables that are especially salient in the context of knowledge production among academics (Burt, 2000; McPherson et al., 2001; Jaffe, Trajtenberg, and Henderson, 1993; Singh, 2005). The first twoinstitution and department—are shared organizational foci (Dahlander and McFarland, 2013). The third— geographic distance-measures physical proximity (Catalini, 2017). The last four-self-identity (imager/clinician), imaging modality, academic rank, and gender-are ascribed and achieved shared characteristics. We used the dummy variables same institution, same department, both imagers, both clinicians, same imaging modality, same rank, both females, and both males to capture whether $i$ and $j$ shared the same characteristic for each of these similarity dimensions. Moreover, we used the continuous variable geographic distance to measure the Euclidean distance of the latitudinal and longitudinal coordinates between the office locations of scientists $i$ and $j$.

\footnotetext{
3 The variable post co-author was only used for the regression models for knowledge transfer and knowledge diffusion.
} 
Prior MeSH keywords. We used the Scopus publication data to capture the count of unique MeSH keywords between scientists $i$ and $j$, measured as the union of the pre-2012 MeSH keyword vectors. ${ }^{4}$

Prior citations. We used a dummy variable that captured whether scientists $i$ and $j$ had cited one another's research prior to the symposium (pre-2012).

Career experience. Lastly, we also used two control variables related to the scientists' relative accumulation of relevant career experience. The first control variable was a dummy variable for "super experts," namely scientists with deep expertise in the latest advanced imaging technologies who were invited to the symposium to facilitate knowledge sharing on advanced imaging technologies. The variable super expert captured whether the pair $\{i, j\}$ had at least one super expert. The second controlled for differences in academic status using rank difference, which was the absolute difference in the academic rank status between pair $\{i, j\}$, ranging from $1=$ undergraduate student to $9=$ professor.

\subsection{Estimation Approach}

To understand how prior knowledge overlap impacts knowledge production, we used ordinary least squares (OLS) regression. We considered all pairs that were "at risk" of knowledge production based on the random assignments of pairs $\{i, j\}$ to the same or different breakout rooms. To avoid problems of heterogeneity across the three nights of the symposium, we restricted our analysis to the full observation of 15,817 pairs that attended on the same night, corresponding to the pairs for whom we collected face-to-face communication data. We also included dummies for each night of the symposium and each breakout room.

We performed a similar analysis using face-to-face communication between pairs $\{i, j\}$ during the symposium. However, a common problem with communication data is that it is endogenous because scientists can still select with whom to interact, even though they are randomly assigned to breakout rooms. To account for this endogeneity issue, we use instrumental variable (IV) regression, and use same room as an instrument for face-to-face communication, to exploit exogenous variation in scientists' exposure to

\footnotetext{
${ }^{4}$ We controlled for the number of common prior MeSH keywords between a dyad rather than their prior publication count because it is a better control for the dependent variable knowledge transfer. That said, there is a high 0.766 correlation between prior MeSH keywords and prior publication count $(p<0.01)$.
} 
other scientists who were assigned to either the same versus different breakout rooms. Like the OLS regression, we also included dummies for each night of the symposium and each breakout room. However, because we used same room as an instrument for face-to-face communication in the first stage, we do not include the control variables co-applicant and post co-author in the IV regressions due to the time interdependencies between the first- and second-stage regressions.

Thus, our analyses used two estimation strategies to predict the relationship between two forms of prior knowledge overlap and knowledge production: one using OLS regression with random assignment of pairs to the same versus different rooms, and another using IV regression of face-to-face communication, with same room as the instrument.

Lastly, there is a well-known estimation problem in dyad regressions because observations are likely to be non-independent. Each individual in a dyad appears in numerous other dyads, which introduces a common-person effect that can cause standard errors to be underestimated (Kenny, Kashy, and Cook, 2006). We address the non-independence problem by estimating robust standard errors that are simultaneously clustered on both members of the dyad (Cameron, Gelbach, and Miller, 2011). Thus, we address this problem using multi-way clustering, developed theoretically by Cameron and colleagues (2011) and implemented for Stata in clus_nway.ado (Kleinbaum, Stuart, and Tushman, 2013). This approach calculates standard errors in three separate co-variance matrices: one clustering on scientist $i$, one on $j$, and one on the intersection of $i$ and $j$. The reported standard errors are clustered on both $i$ and $j$ and estimated on a matrix formed by adding the first two co-variance matrices and then subtracting the third (Kleinbaum, Stuart, and Tushman, 2013).

Both the OLS and IV regression models presented are estimated with multi-way clustering of observations around both the ego and alter of the dyad to correct for common-person effects and around the undirected ego-alter dyad to correct for reciprocal autocorrelation.

\section{RESULTS}


Table 2 shows the summary randomization statistics for the main dyad-level variables for the 15,817 pairs that were randomly assigned to the same vs. different symposium night, and the same vs. different breakout rooms within each night of the symposium. The t-tests show that the randomization achieved balance across the covariates, except for a marginal difference for the organizational foci variables of geographic distance $(p<0.10)$, same institution $(p<0.10)$, and same department $(p<0.10)$ for dyads assigned to the same versus different night, and a significant difference for same rank pairs $(p<0.05)$ and thus rank difference $(p<0.05)$ for pairs assigned to the same versus different breakout rooms. Moreover, Table 3 shows the descriptive statistics for the 15,817 communicating versus non-communicating dyads. The t-test comparisons show significant differences in the distributions for the communicating and noncommunicating pairs. Table 4 shows the correlation matrix for the 15,817 dyads. It is worth noting that there are only modest correlations between the variables.

\subsection{Knowledge Transfer Results}

Table 5 shows the results for the knowledge-transfer analysis and reports the results predicting the percentage of post-symposium MeSH keywords that were transferred from scientist $i$ to $j$ and from scientist $j$ to $i$ for both the OLS regressions (Models 1, 3, 5) and IV regressions (Models 2, 4, 6). In Table 5, Models 1-2 present the baseline models with main effects only; Models 3-4 add the field similarity interaction terms; Models 5-6 add the intellectual similarity interaction terms; and Models 7-8 show the full results with both interaction terms for cognitive similarity.

We theorized in H1a that knowledge sharing would lead to greater knowledge transfer when knowledge-sharing partners spanned different field specialties because there would be more opportunities for exposure to novel ideas. We theorized in H1b that intellectual similarity would have an inverted Ushape effect on the relationship between knowledge sharing and knowledge transfer because partners need some degree of prior related intellectual similarity, but a high level of prior related knowledge would provide limited opportunities for transfer.

First, we found a positive main effect of knowledge sharing on knowledge transfer (Models 1-2). Model 1 shows that knowledge-sharing partners transferred roughly 0.16 percent more MeSH terms when 
they were assigned to the same room and roughly 1.29 percent more MeSH terms when they engaged in face-to-face communication. Second, we found support for H1b but not H1a. Examining Models 7-8, which are the full models with both interaction terms, we observe that knowledge-sharing partners with moderate intellectual similarity transferred roughly 0.39 percent more MeSH terms when assigned to the same room, and transferred roughly 3.62 percent more MeSH terms when they had engaged in face-to-face communication. However, the interaction term with same field specialty is not significant in either Model 7 or 8 . This suggests that knowledge sharing has the greatest effect on knowledge transfer between scientists with a moderate degree of intellectual similarity.

Figures 2 and 3 present the margins plots of these relationships with 95 percent confidence intervals (CIs), and provide greater insight into these relationships. The figures illustrate that while there was no significant difference in MeSH transfer percentage for dyads with moderate and high intellectual similarity that were assigned to different rooms (or did not communicate), we observe that dyads with moderate intellectual similarity were most likely to benefit from being assigned to the same room (or communicating with one another), with little benefit of treatment on dyads sharing either a low or high degree of intellectual similarity.

In summary, our results confirm that an inverted U-shaped relationship exists between intellectual similarity and knowledge transfer, with cooperative effects differentially benefiting pairs with some overlapping intellectual similarity. That said, our findings do not show support for greater knowledge transfer between knowledge-sharing partners spanning different field specialties. Thus, we confirm H1b but not H1a.

\subsection{Knowledge Creation}

Table 6 shows the results for the knowledge-creation analysis and reports the number of copublications between scientists $i$ and $j$ for both the OLS regressions (Models 1, 3, 5) and IV regressions (Models 2, 4, 6). In Table 6, Models 1-2 present the baseline models with main effects only; Models 3-4 add the field similarity interaction terms; Models 5-6 add the intellectual similarity interaction terms; and Models 7-8 show the full results with both interaction terms for cognitive similarity. Lastly, Model 9 
controls for grant awardee to examine whether collaboration persistence was impacted by short-term funding and awards.

We hypothesized in H2a that knowledge-sharing partners would be more likely to collaborate to create new knowledge if they shared the same field specialty, because similarity in education, training, and requirements for career advancement would make interactions more rewarding and more likely to mature into a collaborative relationship. Similarly, we hypothesized in H2b that knowledge-sharing partners would be more likely to collaborate if they had some degree of intellectual similarity, but being too similar would deter collaborations because these individuals would be substitutes for one another. Thus, we hypothesized an inverted U-shaped relationship. Lastly, we hypothesized in H2c that knowledge-sharing partners would be more likely to create new knowledge if they had already formed an elemental collaboration on a grant.

Models 1-2 show that there was no main effect of knowledge sharing on knowledge creation. Examining Models 7-8, which are the full models with both interaction terms, we observe that knowledgesharing partners from the same field specialty co-authored roughly 0.10 fewer publications when they were assigned to the same room, but the evidence is weak and there is no effect for the dyads who engaged in face-to-face communication. Thus, there is partial but weak support for H2a. In Models 7-8, there is also no evidence indicating that knowledge-sharing partners sharing a moderate degree of intellectual similarity were more likely to co-publish. Thus, H2b was also not supported.

Turning to H2c, we observe in Model 7 that grant co-applicants co-published roughly 1.5 research articles together. To test whether the persistence of an elemental collaboration was contingent on being awarded one of the pilot grants, Model 9 includes the variable grant awardee. The coefficient for grant coapplicant remains positive and significant and suggests that, once formed, collaborations are likely to persist (Dahlander and McFarland, 2013), regardless of whether the grant co-applicants were awarded the pilot grant funds. Therefore, we find support for H2c; that is, once formed, elemental collaborations on grant applications are likely to persist into co-publications.

Figures 4 and 5 present the margins plot with 95 percent CI for co-publications and field similarity for same versus different room pairs and communicating versus non-communicating pairs, respectively. 
Figure 4 suggests weak evidence that being assigned to the same room reduced the tendency for collaboration between pairs sharing the same field specialty. Figure 6 presents the margins plot with 95 percent CI for co-publications and grant co-applications and indicates that scientists that co-applied on the grant were more likely to co-publish, while controlling for grant awardee. Recall that, in our setting, only 13 pilot grant awards were given, so the catalyzing force here is the joint work to create the grant application and not necessarily getting the grant itself.

\subsection{Knowledge Diffusion}

Table 7 shows the results for the knowledge-diffusion analysis, reporting the results predicting the number of forward citations between scientists $i$ and $j$ for both the OLS regressions (Models 1, 3, 5) and IV regressions (Models 2, 4, 6). In Table 7, Models 1-2 present the baseline models with main effects only; Models 3-4 add the clinical similarity interaction terms; Models 5-6 add the intellectual similarity interaction terms; and Models 7-8 show the full results with both interaction terms for cognitive similarity.

We hypothesized in H3a and H3b that knowledge would be less likely to diffuse if scientists shared the same field specialty or were more intellectually similar, respectively. We argued that knowledge sharing may heighten competitive effects and secrecy among scientists who could be viewed as highly similar to one another. First, there is no main effect of knowledge sharing on knowledge diffusion (Models 1-2). Second, the findings show support for H3a but not H3b, suggesting that scientists from the same field specialty were more likely to withhold citations from each other. Examining Models 7-8, scientists sharing the same field specialty and assigned to the same room cited each other roughly 0.26 fewer times, while dyads who engaged in face-to-face communication cited each other roughly 2.28 fewer times.

Figures 7 and 8 present the margins plots with 95 percent CI for these relationships. The figures show that pairs sharing the same field specialty were less likely to cite each other if they were assigned to the same versus different breakout rooms, or if they communicated with each other. We note that the negative relationship is stronger for pairs that directly engaged in knowledge sharing (Figure 8), as opposed to pairs who were exposed to each other in the breakout rooms (Figure 7). 
In short, our findings confirm that competitive effects exist between field similarity and knowledge diffusion, but do not show support for competitive effects between intellectual similarity and knowledge diffusion. Hence, we find support for H3a but not H3b.

\subsection{Robustness Checks}

To corroborate our findings, we performed a number of robustness checks to account for alternative factors and explanations. First, we used alternative specifications of the face-to-face communication data for the IV regressions by specifying a continuous variable for interaction time and a threshold approach of at least three minutes of interaction time. This enabled us to determine whether the length of or a minimum time spent together impacted the extent that knowledge sharing affected the knowledge-production process. The results are robust to these alternative specifications.

Second, to determine whether the effects of being from the same field specialty and having intellectual similarity were an artifact of how we measured field and intellectual similarity, we re-ran the models with alternative specifications of the two variables. In the first case, we replaced our measure of field similarity with same crowded field specialty, which was a dummy variable that indicated whether the two scientists were from the top three most represented (“crowded”) clinical specialties—namely neurology, oncology, and neuropsychiatry. Our results replicated for this alternative specification, with the negative interaction effect of being in the same room and from the same crowded field specialty on co-publications becoming more significant $(p<0.05)$. In the second case, we replaced the three-level dichotomous variable for intellectual similarity with a binary variable (split at the median), representing "no intellectual similarity" versus "some intellectual similarity," and the results showed that knowledge transfer was greater in pairs sharing at least some intellectual similarity $(p<0.05)$. Similarly, we also replaced the measure for intellectual similarity with a four-level dichotomous variable (split into quartiles), representing “none," "a little," "moderate," and "a great extent” of intellectual similarity and the results indicated that knowledge transfer was greatest in pairs sharing "a little” intellectual similarity. Third, we ran the OLS regressions in Tables 5-7, Models 1, 3, 5, and 7, using all 402 symposium participants (28,258 dyads) and the results were quite consistent with and in the same direction as the reported results. 


\section{DISCUSSION}

The ability to produce and manage knowledge is a critical source of competitive advantage for organizations of all types. Yet the knowledge-production process is both time-intensive and uncertain. To address this issue, the basic premise of this paper is that serendipity can be engineered to promote greater knowledge sharing and more efficient knowledge production. Taking the view that learning is accretive and that an individual's ability to learn new ideas and concepts is dependent on their prior knowledge and experiences (Hilgard and Bower, 1981), we systematically examined how the degree of cognitive similarity between organizational members impacts the likelihood that knowledge sharing enhances knowledge production. We focused on two dimensions of cognitive similarity, namely the field and intellectual similarity between knowledge-sharing partners, and their effects on three knowledge-production outcomes: knowledge transfer, creation, and diffusion. Whereas field similarity corresponds to the similarity between two organizational members' disciplines of study, intellectual similarity corresponds to the similarity between their knowledge domain areas of interest.

We found both cooperative and competitive effects of cognitive similarity on knowledge production. Cooperative effects appeared in the context of intellectual similarity. While knowledge sharing increases the transfer of scientific concepts between scientists with some shared intellectual overlap in knowledge domain areas, it also reduces the diffusion of scientific knowledge between scientists from the same field. In the post-symposium period, we found that knowledge transfer, proxied using the transfer of MeSH keywords between knowledge-sharing partners, was more likely to occur between scientists who already shared some MeSH keywords in common, and that scientists from the same field were less likely to cite one another if they had interacted during the symposium. These findings suggest that knowledge sharing boosts knowledge production when individuals share some cognitive similarity, but not if they are too similar.

In contrast, cognitive similarity did not have a direct effect on knowledge creation, but we found that scientists who initiated early-stage collaborations with each other on the advanced biomedical imaging 
grant were more likely to persist and co-publish together. We suggest two possible explanations. First, knowledge creation presents a greater relationship burden than either knowledge transfer or diffusion because it entails producing new knowledge that does not already exist on the knowledge frontier (Boudreau and Lakhani, 2015). Therefore, knowledge creation is a fragile process (von Krogh, 1998) that is uncertain and time-consuming, because it involves multiple stages and may take many years to realize (Perry-Smith and Mannucci, 2017). Second, there is strong evidence indicating that people tend to repeat past collaborations, largely because co-author relationships are often strong ties that provide greater trust, security, and socio-emotional support (e.g., Dahlander and McFarland, 2013; Hansen, 1999; Uzzi and Spiro, 2005). In other words, the frictions associated with starting new collaborations may outweigh the potential opportunities for learning, exploration, and synergies (Catalini, 2017).

For these reasons, cognitive similarity between two knowledge-sharing partners may only be one of several factors that drive collaborative knowledge creation (Dahlander and McFarland, 2013). In particular, past research shows that factors such as organizational and social similarities lower transaction costs (Kleinbaum, 2017; Reagans, 2011), and geographic proximity reduces the cost of knowledge sharing, transmission, and monitoring because it enables regular face-to-face communication (Catalini, 2017). Moreover, external collaboration networks are highly dependent on prior social ties (Crescenzi, Nathan, and Rodriguez-Pose, 2016), suggesting that individuals may only invest in more costly instrumental ties when they have established underlying social connectivity (Uzzi, 1997). These factors may explain why collaborations are likely to continue once they have been initiated, thereby locking some individuals out of potentially fruitful collaborations (Dahlander and McFarland, 2013; Uzzi, 1996). In this study, we showed that incentives, such as small prizes and rewards, can aid with the formation of new collaborations and overall productivity (Franzoni, Scellato, and Stephan, 2011).

\subsection{Emphasizing the Role of Cognitive Similarity in Knowledge Sharing and Production}

These findings make a number of contributions to the literature. First, we contribute to the understanding and importance of cognitive similarity in knowledge sharing and knowledge production from a social capital and social network perspective. Social capital has potential value for knowledge production because 
it enables individuals to more efficiently access information and resources from their social network (Adler and Kwon, 2002; Burt, 2009; Coleman 1988). Nahapiet and Ghoshal (1998) identified three dimensions of social capital: structural, relational, and cognitive. However, most scholarly work on social capital has focused on either the structural dimension, which describes the informal configuration of linkages between people or units (Burt 2009), or the relational dimension, which describes the personal relationships people have developed with one another through their history of interactions (Granovetter, 1973), while the cognitive dimension has received much less attention (Maurer and Ebers, 2006). For example, scholarly work on the structural dimension of social capital has indicated that both social cohesion around a relationship and network range with ties to different knowledge pools aid with knowledge-production outcomes (Fleming et al., 2007; Reagans and McEvily, 2003; Obstfeld, 2005), while studies on the relational dimension have identified that tie strength affects the likelihood of knowledge production (Hansen, 1999; Tortoriello, Reagans and McEvily, 2012; Uzzi, 1997).

In contrast, Nahapiet and Ghoshal (1998) describe the cognitive dimension of social capital as similarities in actors' cognitive schemes, interpretations, and systems of meaning (Nahapiet and Ghoshal, 1998). Although some organizational scholars have examined the effects of cognitive similarity on knowledge-sharing and knowledge-production outcomes, prior work tends to be inconsistent in how cognitive similarity is conceptualized. For example, definitions of cognitive similarity have ranged from accumulated relevant experience (Cohen and Levinthal, 1990), technological overlap (Song, Almeida, and Wu, 2003), intellectual overlap (Dahlander and McFarland, 2013), and shared language and orientations (Maurer and Ebers, 2006) to social structure overlap (Reagans and McEvily, 2003). Moreover, it is typically referred to as a unidimensional construct, even though knowledge is multi-faceted and multi-dimensional in nature (Hilgard and Bower 1981). In this study, we have provided some clarity on the antecedents of cognitive similarity by differentiating prior related knowledge into two theoretical dimensions of overlap: field similarity and intellectual similarity. To this end, one implication of our findings is that social network research on social capital must not only consider how cognitive similarity impacts knowledge sharing and 
production but also how different dimensions of cognitive similarity may relate to the structural and relational dimensions of social capital.

\subsection{The Role of New Ties in Knowledge Sharing and Knowledge Production}

The second implication of our findings is greater conceptual clarity on the relationships between new ties, knowledge sharing, and knowledge production. Other researchers have typically focused on the effects of tie strength on knowledge production, differentiating between strong and weak ties. Whereas the research has generally shown that the characteristics of strong ties—namely closeness, long duration, and frequent contact—aid knowledge transfer (e.g., Hansen, 1999; Tortoriello, Reagans, and McEvily 2012; Uzzi, 1997), knowledge creation (e.g., McFadyen, Semadeni, and Canella, 2009; Smith et al., 2005), and knowledge diffusion (e.g., Singh, 2005), weak ties tend to provide efficiency benefits by enabling organizational workers to search for useful, non-redundant knowledge (Hansen, 1999). Rather than weigh the decoupled positive and negative effects of tie strength on knowledge production, our findings suggest that new ties can simultaneously provide the information-search benefits of weak ties and the knowledge-sharing benefits of strong ties (Hansen, 1999) under some conditions.

Our research advances the notion that social foci (Feld, 1981) can create a context that facilitates knowledge sharing and knowledge production. In particular, we show that structured group informationsharing sessions at organizational events can be an efficient way to bridge otherwise disconnected groups and individuals and grant access to novel and non-redundant information (Burt, 2009; Granovetter, 1973). As depicted by the advanced biomedical imaging symposium in our study, these types of events can provide a social boundary (Ingram and Morris, 2007) that enables knowledge-sharing partners to bypass the information-search process (Hansen, 1999) and the tendency for organizational units and firms to compete with one another (Tsai, 2002), thereby fast-tracking the knowledge-sharing process between otherwise disconnected individuals and groups.

Taken one step further, these findings have implications for the design of organizational structures. Organizations have invested a lot of resources into re-designing office spaces to promote serendipitous encounters, interactions, and collaboration between employees (Allen, 1977; Bernstein and Turban, 2018, 
Lee, 2019). Our findings suggest that relatively high-stakes activities centered on a common theme or topic can be an alternative way to promote knowledge sharing that can complement the types of serendipitous but "routine" interactions that are more likely to occur due to the structural implications of organizational and physical proximity for knowledge sharing (Biancani, Dahlander and McFarland, 2004; Kleinbaum, Stuart and Tushman, 2013). An important implication would be to design mixers, off-sites, speed-dates, networking, and other social events that bring together individuals who share some cognitive similarity but are not identical. Given the growth in interdisciplinary science (Wuchty, Jones, and Uzzi, 2007), these types of events can improve the mix of new, weak, and strong ties in a scientist's portfolio of potential collaborators, and are more likely to be effective when there are small prizes or awards associated with them. Lastly, our findings suggest that short-lived interventions can present an attractive and cost-effective way to facilitate temporary co-location (Chai and Freeman, 2019) and serendipitous knowledge sharing to have lasting effects on knowledge production.

\subsection{The Multiple and Long-Run Effects of Knowledge Sharing on Knowledge Production}

The most important implication of our findings is that we show that knowledge sharing can have multiple, sometimes differentiated, effects on knowledge production in the long run. Although prior scholars have considered knowledge production to consist of multiple knowledge-related outcomes (e.g., Grant, 1996), much of this work tends to focus on a single knowledge-production outcome (such as knowledge transfer) rather than considering the interrelated effects that one outcome may have on another (Hansen, Mors, and Lovas, 2005). Another line of work tends to focus on the antecedents or "front-end" of knowledge sharing and its subsequent effects on knowledge transfer (e.g., Hansen, 1999; Hansen, Mors, and Lovas, 2005; Szulanski, 1996). Building on insights from prior work, we instead focus on the "back-end” of knowledge sharing and the knowledge-production process. In this research, we have articulated the differences between knowledge transfer, creation, and diffusion as the movement, generation, and dissemination of facts, relationship, and insights across different individuals, groups, and organizations, respectively. We have argued that knowledge transfer may occur with greater ease than knowledge creation because it places a lesser burden on the given knowledge-sharing partners, and we have shown that knowledge transfer does 
not necessarily entail knowledge diffusion, particularly when it involves social recognition of perceived competitors. Our findings indicate that research considering only one knowledge-production outcome may be incomplete because it does not consider the possible countervailing effects that one knowledgeproduction-related outcome may have on another.

We acknowledge that our ability to investigate multiple outcomes of knowledge production was to a large extent facilitated by our access to multiple sources of data, namely a natural field experiment combined with direct observations of face-to-face communications and archival publication data. These multiple sources of data enabled us to investigate the causal relationships between knowledge sharing and long-term knowledge-production outcomes, which sets this research apart from other studies that have only had access to archival data or survey data. Although such combinations of data sources are rare and difficult to come by, we suggest that researchers pay more attention to research designs that include natural field experiments to advance a robust theory of knowledge sharing and knowledge production.

\section{LIMITATIONS AND FUTURE RESEARCH}

In this research, we have made a thorough effort to analyze how knowledge sharing leads to knowledge production in the sciences. Although we focused on an interdisciplinary setting in a large, highly selective university and its affiliated institutions and hospitals, we believe the implications of our findings extend to similar types of cross-disciplinary knowledge-sharing opportunities that emerge in non-university settings.

However, as with all research, our study has some empirical limitations. First, our study setting may be interpreted as a best-case scenario in fostering cross-disciplinary knowledge production, as we must draw a boundary around the network and incentives under consideration. The symposium was highly structured to facilitate knowledge sharing, while knowledge production is a core activity for academics. Our focus on the life sciences also draws upon a specific population. Haas and Park (2010) have suggested that professional groups may provide a strong basis for normative behaviors with regard to publication, withholding, and secrecy. In the sciences, norms for intragroup competition may be magnified to some extent by the promising returns on commercializing one’s findings and discoveries (Blumenthan et al., 
1997) and the intense competition associated with the "winner-takes-all” model of rewards and recognition for one’s achievements (Stephan, 1996). We recognize that other settings may promote more openness and cooperation and a possible future direction would be to extend this research to a different context, such as the social sciences (where there are fewer opportunities for commercialization) or a non-academic setting. Although sociometric badges enabled us to directly observe patterns of face-to-face communication between scientists, we did not have the means to record the actual content of the communication, which would have provided greater insight into the topics and sentiment of their communication exchanges.

Moreover, our experimental design did not capture the underlying interpersonal networks of our sample population, beyond their prior coauthor networks. Prior research suggests that interpersonal networks facilitate knowledge transfer and diffusion (Uzzi, 1997; Obstfeld, 2005; Singh, 2005) and that local network properties, such as transitivity and mutual third-party ties (Coleman, 1988), may shape the likelihood that knowledge sharing evolves into new knowledge production. Future work may consider how the different dimensions of social capital—cognitive, structural, and relational—jointly affect the knowledge-production process.

In our empirical analysis of field similarity, we chose a dichotomous measure of field similarity rather than a continuous measure. We acknowledge that some fields (such as neurology and neuropsychiatry) may be more similar to each other than other fields (such as neurology and hematology), but we leave this as a potential area for future research to explore the intricacies of increasing overlap in field similarity on knowledge sharing and production. Furthermore, some recent work has highlighted the role of negative citations in limiting and correcting previous results (Catalini, Lacetera, and Oettl, 2015). Future research could investigate the likelihood of negative citations emerging from individuals with greater or lesser degrees of field or intellectual similarities. We also focused on dyadic ties rather than teams. Although many intimate communication exchanges occur at the dyad level, interactions that occur among three or more individuals have a very different purpose and focus (Heider, 1946). Some research has turned to examine team-assembly mechanisms (Guimera et al. 2005) and a possible future direction would be to more closely examine the drivers of group knowledge sharing that shape knowledge-production processes. 
Another potential avenue for future research is to examine the interaction between field and intellectual similarities. We have shown that knowledge transfer, creation, and diffusion are driven by different cognitive dimensions, but we have not examined the potential for these processes to shape one another to impact knowledge production. For example, although we found that individuals from the same field specialty may become less likely to collaborate after knowledge sharing, these individuals may become more likely to collaborate if they share a moderate degree of intellectual similarity because of the unshared intellectual areas that are unique to each person.

Lastly, this study was not a performative assessment of the effect of knowledge sharing on the quality or performance of knowledge outcomes. Rather, we focused on the building blocks of knowledge production — that is, how serendipitous knowledge sharing may enhance the knowledge-production process. Due to our focus, we did not address the quality or impact of innovation or compare the relative significance of engineered serendipitous encounters with other forms of non-engineered “organic” encounters. We leave it to future work to identify which factors explain the highest-quality knowledge-production outcomes. 


\section{REFERENCES}

Adams, J. D., Black, G. C., Clemmons, J. R., \& Stephan, P. E. (2005). Scientific teams and institutional collaborations: Evidence from US universities, 1981-1999. Research Policy, 34(3), 259-285.

Adler, P. S., \& Kwon, S. W. (2002). Social capital: Prospects for a new concept. Academy of Management Review, 27(1), 17-40.

Allen, T. J. (1977). Managing the flow of technology: Technology transfer and the dissemination of technological information within the R\&D organisation. Cambridge, MA: The Massachusetts Institute of Technology.

Amabile, T. M. (1993). Motivational synergy: Toward new conceptualizations of intrinsic and extrinsic motivation in the workplace. Human Resource Management Review, 3(3), 185-201.

Argote, L. (1999). Organizational Learning: Creating. Retaining and Transferring. Boston, MA: Kluwer.

Argote, L., \& Ingram, P. (2000). Knowledge transfer: A basis for competitive advantage in firms. Organizational Behavior and Human Decision Processes, 82(1), 150-169.

Argote, L., McEvily, B., \& Reagans, R. (2003). Managing knowledge in organizations: An integrative framework and review of emerging themes. Management Science, 49(4), 571-582.

Arrow, K. 1962. Economic welfare and the location of resources for invention. The Rate and Direction of Inventive Activity. Princeton, NJ: Princeton University Press.

Arthur, M. B., \& Rousseau, D. M. (1996). A career lexicon for the 21st century. Academy of Management Perspectives, 10(4), 28-39.

Azoulay, P., Liu, C.C. and Stuart, T.E. (2017). Social influence given (partially) deliberate matching: Career imprints in the creation of academic entrepreneurs. American Journal of Sociology, 122(4), 1223-1271.

Azoulay, P., Graff Zivin, J. S., Li, D., \& Sampat, B. N. (2018). Public R\&D investments and privatesector patenting: evidence from NIH funding rules. The Review of Economic Studies, 86(1), 117152.

Benner, M.J. and Tushman, M. (2002). Process management and technological innovation: A longitudinal study of the photography and paint industries. Administrative Science Quarterly, 47(4), 676-707.

Bernstein, E. S., \& Turban, S. (2018). The impact of the 'open' workspace on human collaboration. Philosophical Transactions of the Royal Society B: Biological Sciences, 373(1753), 20170239.

Biancani, S., McFarland, D. A., \& Dahlander, L. (2014). The semiformal organization. Organization Science, 25(5), 1306-1324.

Blumenthal, D., Campbell, E. G., Anderson, M. S., Causino, N., \& Louis, K. S. (1997). Withholding research results in academic life science: evidence from a national survey of faculty. Jama, 277(15), 1224-1228.

Boland Jr, R. J., \& Tenkasi, R. V. (1995). Perspective making and perspective taking in communities of knowing. Organization Science, 6(4), 350-372.

Börner, K., Contractor, N., Falk-Krzesinski, H. J., Fiore, S. M., Hall, K. L., Keyton, J., Spring, B., Stokols, D., Trochim, W. \& Uzzi, B. (2010). A multi-level systems perspective for the science of team science. Science Translational Medicine, 2(49), 1-5.

Boudreau, K. J., Brady, T., Ganguli, I., Gaule, P., Guinan, E., Hollenberg, A., \& Lakhani, K. R. (2017). A field experiment on search costs and the formation of scientific collaborations. Review of Economics and Statistics, 99(4), 565-576.

Boudreau, K. J., Guinan, E. C., Lakhani, K. R., \& Riedl, C. (2016). Looking across and looking beyond the knowledge frontier: Intellectual distance, novelty, and resource allocation in science. Management Science, 62(10), 2765-2783.

Boudreau, K. J., \& Lakhani, K. R. (2015). “Open” disclosure of innovations, incentives and follow-on reuse: Theory on processes of cumulative innovation and a field experiment in computational biology. Research Policy, 44(1), 4-19.

Bower, G. H., \& Hilgard, E. R. (1981). Theories of learning. Prentice-Hall. 
Brewer, M. B. (1991). The social self: On being the same and different at the same time. Personality and Social Psychology Bulletin, 17(5), 475-482.

Brown, J. S., \& Duguid, P. (1991). Organizational learning and communities-of-practice: Toward a unified view of working, learning, and innovation. Organization Science, 2(1), 40-57.

Brown, J. S., \& Duguid, P. (2001). Knowledge and organization: A social-practice perspective. Organization Science, 12(2), 198-213.

Brusoni, S., Prencipe, A., \& Pavitt, K. (2001). Knowledge specialization, organizational coupling, and the boundaries of the firm: why do firms know more than they make? Administrative Science Quarterly, 46(4), 597-621.

Bunderson, J. S., \& Sutcliffe, K. M. (2002). Comparing alternative conceptualizations of functional diversity in management teams: Process and performance effects. Academy of Management Journal, 45(5), 875-893.

Burt, R. S. (2001). Attachment, decay, and social network. Journal of Organizational Behavior: The International Journal of Industrial, Occupational and Organizational Psychology and Behavior, 22(6), 619-643.

Burt, R.S., 2009. Structural holes: The social structure of competition. Cambridge, MA: Harvard University Press.

Campanario, J. M., \& Acedo, E. (2007). Rejecting highly cited papers: The views of scientists who encounter resistance to their discoveries from other scientists. Journal of the American Society for Information Science and Technology, 58(5), 734-743.

Campbell, E. G., Clarridge, B. R., Gokhale, M., Birenbaum, L., Hilgartner, S., Holtzman, N. A., \& Blumenthal, D. (2002). Data withholding in academic genetics: evidence from a national survey. Jama, 287(4), 473-480.

Cameron, A. C., Gelbach, J. B., \& Miller, D. L. (2011). Robust inference with multiway clustering. Journal of Business \& Economic Statistics, 29(2), 238-249.

Carlile, P. R. (2004). Transferring, translating, and transforming: An integrative framework for managing knowledge across boundaries. Organization Science, 15(5), 555-568.

Catalini, C. (2017). Microgeography and the direction of inventive activity. Management Science, 64(9), 4348-4364.

Chai, S., \& Freeman, R. B. (2019). Temporary Colocation and Collaborative Discovery: Who Confers at Conferences. Strategic Management Journal, 40(13), 1-27.

Cockburn, I. M., \& Henderson, R. M. (1998). Absorptive capacity, coauthoring behavior, and the organization of research in drug discovery. The Journal of Industrial Economics, 46(2), 157-182.

Cohen, W. M., \& Levinthal, D. A. (1990). Absorptive capacity: A new perspective on learning and innovation. Administrative Science Quarterly, 35(1), 128-152.

Coleman, J. S. (1988). Social capital in the creation of human capital. American Journal of Sociology, 94, S95-S120.

Coletti, M. H., \& Bleich, H. L. (2001). Medical subject headings used to search the biomedical literature. Journal of the American Medical Informatics Association, 8(4), 317-323.

Crescenzi, R., Nathan, M., \& Rodríguez-Pose, A. (2016). Do inventors talk to strangers? On proximity and collaborative knowledge creation. Research Policy, 45(1), 177-194.

Daft, R. L., \& Lengel, R. H. (1986). Organizational information requirements, media richness and structural design. Management Science, 32(5), 554-571.

Dahlander, L., \& McFarland, D. A. (2013). Ties that last: Tie formation and persistence in research collaborations over time. Administrative Science Quarterly, 58(1), 69-110.

Ding, W. W., Levin, S. G., Stephan, P. E., \& Winkler, A. E. (2010). The impact of information technology on academic scientists' productivity and collaboration patterns. Management Science, 56(9), 1439-1461.

Eagle, N., Pentland, A. S., \& Lazer, D. (2009). Inferring friendship network structure by using mobile phone data. Proceedings of the National Academy of Sciences, 106(36), 15274-15278.

Ellis, H. C. (1965). The transfer of learning. New York: MacMillan. 
Ernst, D., \& Kim, L. (2002). Global production networks, knowledge diffusion, and local capability formation. Research Policy, 31(8-9), 1417-1429.

Fayard, A. L., \& Weeks, J. (2007). Photocopiers and water-coolers: The affordances of informal interaction. Organization Studies, 28(5), 605-634.

Feld, S. L. (1981). The focused organization of social ties. American Journal of Sociology, 86(5), 10151035.

Ferguson, J. P., \& Hasan, S. (2013). Specialization and career dynamics: Evidence from the Indian Administrative Service. Administrative Science Quarterly, 58(2), 233-256.

Fleming, L. (2001). Recombinant uncertainty in technological search. Management Science, 47(1), 117132.

Fleming, L., Mingo, S., \& Chen, D. (2007). Collaborative brokerage, generative creativity, and creative success. Administrative Science Quarterly, 52(3), 443-475.

Fleming, L., \& Sorenson, O. (2001). Technology as a complex adaptive system: evidence from patent data. Research Policy, 30(7), 1019-1039.

Flynn, F. J. (2005). Identity orientations and forms of social exchange in organizations. Academy of Management Review, 30(4), 737-750.

Franzoni, C., Scellato, G., \& Stephan, P. (2011). Changing incentives to publish. Science, 333(6043), 702-703.

Galunic, D. C., \& Rodan, S. (1998). Resource recombinations in the firm: Knowledge structures and the potential for Schumpeterian innovation. Strategic Management Journal, 19(12), 1193-1201.

Gerber, A.S. \& Green, D.P. (2009). Field experiments and natural experiments. In R. Goodin (ed.) Oxford Handbook of Political Science. New York: Oxford University Press

Gavetti, G., \& Levinthal, D. (2000). Looking forward and looking backward: Cognitive and experiential search. Administrative Science Quarterly, 45(1), 113-137.

Granovetter, M. 1973. The strength of weak ties. American Journal of Sociology, 78, 1360-1380.

Granovetter, M. (2005). The impact of social structure on economic outcomes. Journal of Economic Perspectives, 19(1), 33-50.

Grant, R. M. (1996). Toward a knowledge-based theory of the firm. Strategic Management Journal, 17(S2), 109-122.

Grant, R. M. (1996). Prospering in dynamically-competitive environments: Organizational capability as knowledge integration. Organization Science, 7(4), 375-387.

Guimera, R., Uzzi, B., Spiro, J., \& Amaral, L. A. N. (2005). Team assembly mechanisms determine collaboration network structure and team performance. Science, 308(5722), 697-702.

Haas, M. R., \& Hansen, M. T. (2005). When using knowledge can hurt performance: The value of organizational capabilities in a management consulting company. Strategic Management Journal, 26(1), 1-24.

Haas, M. R., \& Hansen, M. T. (2007). Different knowledge, different benefits: Toward a productivity perspective on knowledge sharing in organizations. Strategic Management Journal, 28(11), 1133-1153.

Haas, M. R., \& Park, S. (2010). To share or not to share? Professional norms, reference groups, and information withholding among life scientists. Organization Science, 21(4), 873-891.

Haeussler, C., Jiang, L., Thursby, J., \& Thursby, M. (2014). Specific and general information sharing among competing academic researchers. Research Policy, 43(3), 465-475.

Hansen, M. T. (1999). The search-transfer problem: The role of weak ties in sharing knowledge across organization subunits. Administrative Science Quarterly, 44(1), 82-111.

Hansen, M. T., \& Haas, M. R. (2001). Competing for attention in knowledge markets: Electronic document dissemination in a management consulting company. Administrative Science Quarterly, 46(1), 1-28.

Hansen, M. T., Mors, M. L., \& Løvås, B. (2005). Knowledge sharing in organizations: Multiple networks, multiple phases. Academy of Management Journal, 48(5), 776-793.

Hagstrom, W. O. (1974). Competition in science. American Sociological Review, 1-18. 
Hardy, C., Phillips, N., \& Lawrence, T. B. (2003). Resources, knowledge and influence: The organizational effects of interorganizational collaboration. Journal of Management Studies, 40(2), 321-347.

Hargadon, A. B. (1998). Firms as knowledge brokers: Lessons in pursuing continuous innovation. California Management Review, 40(3), 209-227.

Harrison, G. W., \& List, J. A. (2004). Field experiments. Journal of Economic Literature, 42(4), 10091055.

Heider, F. (1946). Attitudes and cognitive organization. The Journal of Psychology, 21(1), 107-112.

Hogg, M. A., Sherman, D. K., Dierselhuis, J., Maitner, A. T., \& Moffitt, G. (2007). Uncertainty, entitativity, and group identification. Journal of Experimental Social Psychology, 43(1), 135-142.

Hogg, M. A. (2000). Subjective uncertainty reduction through self-categorization: A motivational theory of social identity processes. European Review of Social Psychology, 11(1), 223-255.

Hong, W., \& Walsh, J. P. (2016). For money or glory? Commercialization, competition, and secrecy in the entrepreneurial university. The Sociological Quarterly, 50(1), 145-171.

Hornsey, M. J., \& Jetten, J. (2004). The individual within the group: Balancing the need to belong with the need to be different. Personality and Social Psychology Review, 8(3), 248-264.

Huber, G. P. (1991). Organizational learning: The contributing processes and the literatures. Organization Science, 2(1), 88-115.

Hwang, H., \& Powell, W. W. (2009). The rationalization of charity: The influences of professionalism in the nonprofit sector. Administrative Science Quarterly, 54(2), 268-298.

Ingram, P., \& Morris, M. W. (2007). Do people mix at mixers? Structure, homophily, and the "life of the party”. Administrative Science Quarterly, 52(4), 558-585.

Inkpen, A. C., \& Dinur, A. (1998). Knowledge management processes and international joint ventures. Organization Science, 9(4), 454-468.

Inkpen, A. C., \& Tsang, E. W. (2005). Social capital, networks, and knowledge transfer. Academy of Management Review, 30(1), 146-165.

Jaffe, A. B., Trajtenberg, M., \& Henderson, R. (1993). Geographic localization of knowledge spillovers as evidenced by patent citations. The Quarterly Journal of Economics, 108(3), 577-598.

Janis, I. L. (1972). Victims of groupthink: A psychological study of foreign-policy decisions and fiascoes. Boston, MA: Houghton Mifflin.

Jeppesen, L. B., \& Lakhani, K. R. (2010). Marginality and problem-solving effectiveness in broadcast search. Organization Science, 21(5), 1016-1033.

Jones, B. F. (2009). The burden of knowledge and the "death of the renaissance man": Is innovation getting harder? The Review of Economic Studies, 76(1), 283-317.

Kabo, F. W., Cotton-Nessler, N., Hwang, Y., Levenstein, M. C., \& Owen-Smith, J. (2014). Proximity effects on the dynamics and outcomes of scientific collaborations. Research Policy, 43(9), 14691485.

Kenny, D. A., Kashy, D. A., \& Cook, W. L. (2006). Dyadic data analysis. New York, NY: Guilford press.

Kim, T., McFee, E., Olguin, D. O., Waber, B., \& Pentland, A. S. (2012). Sociometric badges: Using sensor technology to capture new forms of collaboration. Journal of Organizational Behavior, 33(3), 412-427.

Khanna, T., Gulati, R., \& Nohria, N. (1998). The dynamics of learning alliances: Competition, cooperation, and relative scope. Strategic Management Journal, 19(3), 193-210.

Kleinbaum, A.M., Stuart, T.E. and Tushman, M.L. (2013). Discretion within constraint: Homophily and structure in a formal organization. Organization Science, 24(5), 1316-1336.

Kleinbaum, A. M. (2017). Reorganization and tie decay choices. Management Science, 64(5), 2219-2237.

Kogut, B., \& Zander, U. (1992). Knowledge of the firm, combinative capabilities, and the replication of technology. Organization Science, 3(3), 383-397.

Lakhani, K., \& Eric, A. (2000). von Hippel (2003), "How open source software works:" free" user-to-user assistance”. Research Policy, 32(6), 925-943. 
Landfeld, C. S. (2016). The structure and function of departments of medicine. Transactions of the American Clinical and Climatological Association, 127, 196-211.

Larson Jr, J. R., \& Christensen, C. (1993). Groups as problem-solving units: Toward a new meaning of social cognition. British Journal of Social Psychology, 32(1), 5-30.

Latour, B., \& Woolgar, S. (1979). Laboratory life. Beverly Hills, CA: Sage.

Lazarsfeld, P. F., \& Merton, R. K. (1954). Friendship as a social process: A substantive and methodological analysis. Freedom and Control in Modern Society, 18(1), 18-66.

Lee, S. (2019). Learning-by-Moving: Can Reconfiguring Spatial Proximity Between Organizational Members Promote Individual-level Exploration? Organization Science, 30(3), 467-488.

Levin, D. Z., \& Cross, R. (2004). The strength of weak ties you can trust: The mediating role of trust in effective knowledge transfer. Management Science, 50(11), 1477-1490.

Levinthal, D. A., \& March, J. G. (1993). The myopia of learning. Strategic Management Journal, 14(S2), 95-112.

Levitt, B., \& March, J. G. (1988). Organizational learning. Annual Review of Sociology, 14(1), 319-338.

Levin, S. G., \& Stephan, P. E. (1991). Research productivity over the life cycle: Evidence for academic scientists. The American Economic Review, 114-132.

Lindsay, P. H., \& Norman, D. A. (1977). Human information processing. Orlando, FL: Academic Press,

March, J. G. (1991). Exploration and exploitation in organizational learning. Organization Science, 2(1), 71-87.

Mairesse, J. and Turner, L. (2005). Measurement and explanation of the intensity of co-publication in scientific research: An analysis at the laboratory level (No. w11172). National Bureau of Economic Research.

Marsden, P. V., \& Campbell, K. E. (1984). Measuring tie strength. Social Forces, 63(2), 482-501.

Maurer, I. and Ebers, M. (2006). Dynamics of social capital and their performance implications: Lessons from biotechnology start-ups. Administrative Science Quarterly, 51(2), 262-292.

McFadyen, M. A., \& Cannella Jr, A. A. (2004). Social capital and knowledge creation: Diminishing returns of the number and strength of exchange relationships. Academy of Management Journal, 47(5), 735-746.

McFadyen, M. A., Semadeni, M., \& Cannella Jr, A. A. (2009). Value of strong ties to disconnected others: Examining knowledge creation in biomedicine. Organization Science, 20(3), 552-564.

McPherson, M., Smith-Lovin, L., \& Cook, J. M. (2001). Birds of a feather: Homophily in social networks. Annual Review of Sociology, 27(1), 415-444.

Merton, R. K. (1968). The Matthew effect in science: The reward and communication systems of science are considered. Science, 159(3810), 56-63.

Merton, R. K. (1973). The sociology of science: Theoretical and empirical investigations. Chicago, IL: University of Chicago Press.

Mitroff, I. I. (1974). The subjective side of science: A philosophical inquiry into the psychology of the Apollo moon scientists, Amsterdam, NL: Elsevier.

Mollica, K. A., Gray, B., \& Trevino, L. K. (2003). Racial homophily and its persistence in newcomers' social networks. Organization Science, 14(2), 123-136.

Morris, M. W., Podolny, J., \& Sullivan, B. N. (2008). Culture and coworker relations: Interpersonal patterns in American, Chinese, German, and Spanish divisions of a global retail bank. Organization Science, 19(4), 517-532.

Murray, F., \& O'Mahony, S. (2007). Exploring the foundations of cumulative innovation: Implications for organization science. Organization Science, 18(6), 1006-1021.

Nagle, F., \& Teodoridis, F. Jack of All Trades and Master of Knowledge: The Role of Diversification in New Distant Knowledge Integration. Strategic Management Journal 1-19.

Nahapiet, J., \& Ghoshal, S. (1998). Social capital, intellectual capital, and the organizational advantage. Academy of Management Review, 23(2), 242-266.

Nelson, R. R., \& Winter, S. G. (1982). The Schumpeterian tradeoff revisited. The American Economic Review, 72(1), 114-132. 
Nonaka, I. (1994). A dynamic theory of organizational knowledge creation. Organization Science, 5(1), 14-37.

Pain, E. (2018, February 28). Collaborating for the win. Retrieved from https://www.sciencemag.org/careers/2018/02/collaborating-win

Page, S. E. (2007). Making the difference: Applying a logic of diversity. Academy of Management Perspectives, 21(4), 6-20.

Perry-Smith, J. E., \& Mannucci, P. V. (2017). From creativity to innovation: The social network drivers of the four phases of the idea journey. Academy of Management Review, 42(1), 53-79.

Perry-Smith, J. E., \& Shalley, C. E. (2003). The social side of creativity: A static and dynamic social network perspective. Academy of Management Review, 28(1), 89-106.

Perry-Smith, J. E., \& Shalley, C. E. (2014). A social composition view of team creativity: The role of member nationality-heterogeneous ties outside of the team. Organization Science, 25(5), 1434 1452.

Phelps, C., Heidl, R., \& Wadhwa, A. (2012). Knowledge, networks, and knowledge networks: A review and research agenda. Journal of Management, 38(4), 1115-1166.

Podolny, J. M. (1994). Market uncertainty and the social character of economic exchange. Administrative Science Quarterly, 39(3), 458-483.

Polanyi, M. (1966). The logic of tacit inference. Philosophy, 41(155), 1-18.

Powell, W. W., Koput, K. W., \& Smith-Doerr, L. (1996). Interorganizational collaboration and the locus of innovation: Networks of learning in biotechnology. Administrative Science Quarterly, 116145.

Powell, W.W., White, D.R., Koput, K.W. and Owen-Smith, J. (2005). Network dynamics and field evolution: The growth of interorganizational collaboration in the life sciences. American Journal of Sociology, 110(4), 1132-1205.

Rawlings, C. M., McFarland, D. A., Dahlander, L., \& Wang, D. (2015). Streams of thought: Knowledge flows and intellectual cohesion in a multidisciplinary era. Social Forces, 93(4), 1687-1722.

Reagans, R. (2011). Close encounters: Analyzing how social similarity and propinquity contribute to strong network connections. Organization Science, 22(4), 835-849.

Reagans, R., \& McEvily, B. (2003). Network structure and knowledge transfer: The effects of cohesion and range. Administrative Science Quarterly, 48(2), 240-267.

Reschke, B. P., Azoulay, P., \& Stuart, T. E. (2018). Status spillovers: The effect of status-conferring prizes on the allocation of attention. Administrative Science Quarterly, 63(4), 819-847.

Rosen, S. (1983). Specialization and human capital. Journal of Labor Economics, 1(1), 43-49.

Rosenkopf, L., \& Almeida, P. (2003). Overcoming local search through alliances and mobility. Management Science, 49(6), 751-766.

Schulz, M. (2001). The uncertain relevance of newness: Organizational learning and knowledge flows. Academy of Management Journal, 44(4), 661-681.

Schumpeter, J. A. 1934. The Theory of Economic Development: An Inquiry into Profits, Capital, Credit, Interest, and the Business Cycle. Cambridge, MA: Harvard University Press.

Singh, J. (2005). Collaborative networks as determinants of knowledge diffusion patterns. Management Science, 51(5), 756-770.

Singh, J., \& Fleming, L. (2010). Lone inventors as sources of breakthroughs: Myth or reality? Management Science, 56(1), 41-56.

Smith, K. G., Collins, C. J., \& Clark, K. D. (2005). Existing knowledge, knowledge creation capability, and the rate of new product introduction in high-technology firms. Academy of Management Journal, 48(2), 346-357.

Song, J., Almeida, P., \& Wu, G. (2003). Learning-by-hiring: when is mobility more likely to facilitate interfirm knowledge transfer? Management Science, 49(4), 351-365.

Staw, B.M. and Epstein, L.D. (2000). What bandwagons bring: Effects of popular management techniques on corporate performance, reputation, and CEO pay. Administrative Science Quarterly, 45(3), 523-556. 
Stephan, P. E. (1996). The economics of science. Journal of Economic Literature, 34(3), 1199-1235.

Storper, M. and Venables, A.J. (2004). Buzz: face-to-face contact and the urban economy. Journal of Economic Geography, 4(4), 351-370.

Sztompka, P. (2007). Trust in science: Robert K. Merton's inspirations. Journal of Classical Sociology, $7(2), 211-220$.

Szulanski, G. (1996). Exploring internal stickiness: Impediments to the transfer of best practice within the firm. Strategic Management Journal, 17(S2), 27-43.

Tajfel, H. (1979). Individuals and groups in social psychology. British Journal of Social and Clinical Psychology, 18(2), 183-190.

Teece, D. J. (1977). Technology transfer by multinational firms: The resource cost of transferring technological know-how. The Economic Journal, 87(346), 242-261.

Teece, D. J. (1986). Profiting from technological innovation: Implications for integration, collaboration, licensing and public policy. Research Policy, 15(6), 285-305.

Thomas-Hunt, M. C., Ogden, T. Y., \& Neale, M. A. (2003). Who's really sharing? Effects of social and expert status on knowledge exchange within groups. Management Science, 49(4), 464-477.

Thompson AE. A Physician's Education. JAMA. 2014;312(22):2456. doi:10.1001/jama.2014.16394

Treem, J. W., \& Leonardi, P. M. (2013). Social media use in organizations: Exploring the affordances of visibility, editability, persistence, and association. Annals of the International Communication Association, 36(1), 143-189.

Tsai, W. (2001). Knowledge transfer in intraorganizational networks: Effects of network position and absorptive capacity on business unit innovation and performance. Academy of Management Journal, 44(5), 996-1004.

Tsai, W. (2002). Social structure of “coopetition” within a multiunit organization: Coordination, competition, and intraorganizational knowledge sharing. Organization Science, 13(2), 179-190.

Tsai, W., \& Ghoshal, S. (1998). Social capital and value creation: The role of intrafirm networks. Academy of Management Journal, 41(4), 464-476.

Usher, A. P. (1954). A history of mechanical inventions, Cambridge, MA: Harvard University Press.

Uzzi, B. (1996). The sources and consequences of embeddedness for the economic performance of organizations: The network effect. American Sociological Review, 674-698.

Uzzi, B. (1997). Social structure and competition in interfirm networks: The paradox of embeddedness. Administrative Science Quarterly, 35-67.

Uzzi, B., \& Spiro, J. (2005). Collaboration and creativity: The small world problem. American Journal of Sociology, 111(2), 447-504.

Uzzi, B., Mukherjee, S., Stringer, M., \& Jones, B. (2013). Atypical combinations and scientific impact. Science, 342(6157), 468-472.

Von Hippel, E. (1994). “Sticky information” and the locus of problem solving: implications for innovation. Management Science, 40(4), 429-439.

Vural, M.O., Dahlander, L., \& George, G. (2013). Collaborative benefits and coordination costs: Learning and capability development in science. Strategic Entrepreneurship Journal, 7(2), 122-137.

Wang, J. (2016). Knowledge creation in collaboration networks: Effects of tie configuration. Research Policy, 45(1), 68-80.

Wang, J., Veugelers, R., \& Stephan, P. (2017). Bias against novelty in science: A cautionary tale for users of bibliometric indicators. Research Policy, 46(8), 1416-1436.

Weingart, P. (2000). "Interdisciplinarity: The paradoxical discourse.” In P. Weingart and N. Stehr (eds.), Practicing Interdisciplinarity: 25-42. Toronto: University of Toronto Press.

Walsh, J. P., \& Hong, W. (2003). Secrecy is increasing in step with competition. Nature, 422(6934), 801.

Wuchty, S., Jones, B. F., \& Uzzi, B. (2007). The increasing dominance of teams in production of knowledge. Science, 316(5827), 1036-1039.

Von Krogh, G. (1998). Care in knowledge creation. California Management Review, 40(3), 133-153. 
Zander, U., \& Kogut, B. (1995). Knowledge and the speed of the transfer and imitation of organizational capabilities: An empirical test. Organization Science, 6(1), 76-92.

Zuckerman, Harriet (1988) 'The Sociology of Science’, pp. 511-74 in Neil J. Smelser (ed.) Handbook of Sociology. Newbury Park, CA: Sage. 
Table 1. Relationships Between Prior Knowledge Overlap and Knowledge Production

\begin{tabular}{|c|c|c|c|c|c|}
\hline Mechanism & $\begin{array}{l}\text { General } \\
\text { Description }\end{array}$ & Transfer & Creation & Diffusion & Hypotheses \\
\hline $\begin{array}{l}\text { Field } \\
\text { similarity }\end{array}$ & $\begin{array}{l}\text { Individuals who } \\
\text { share the same } \\
\text { field specialty } \\
\text { have similar } \\
\text { training, } \\
\text { backgrounds, and } \\
\text { experiences. }\end{array}$ & $\begin{array}{l}\text { Negative effect } \\
\text { of shared field } \\
\text { specialty. } \\
\text { Individuals from } \\
\text { the same field } \\
\text { specialty have } \\
\text { limited } \\
\text { opportunities for } \\
\text { learning new } \\
\text { knowledge and } \\
\text { transferring } \\
\text { knowledge. }\end{array}$ & $\begin{array}{l}\text { Positive effect of } \\
\text { shared field } \\
\text { specialty. } \\
\text { Collaborations } \\
\text { are a significant } \\
\text { commitment and } \\
\text { investment in a } \\
\text { relationship and } \\
\text { emerge from } \\
\text { shared } \\
\text { experiences that } \\
\text { come from } \\
\text { similar } \\
\text { backgrounds, } \\
\text { training, skills, } \\
\text { and expertise. }\end{array}$ & $\begin{array}{l}\text { Negative effect } \\
\text { of shared field } \\
\text { specialty. } \\
\text { Competition for } \\
\text { scarce resources } \\
\text { means that } \\
\text { individuals from } \\
\text { the same field } \\
\text { are } \\
\text { disincentivized } \\
\text { from } \\
\text { acknowledging } \\
\text { their peers from } \\
\text { the same field } \\
\text { specialty due to } \\
\text { winner-takes-all } \\
\text { and zero-sum } \\
\text { nature of } \\
\text { recognition and } \\
\text { rewards in } \\
\text { science. }\end{array}$ & $\begin{array}{l}\text { H1a. Knowledge } \\
\text { sharing is more } \\
\text { likely to lead to } \\
\text { knowledge } \\
\text { transfer when } \\
\text { individuals span } \\
\text { different field } \\
\text { specialties. } \\
\text { H2a. Knowledge } \\
\text { sharing is more } \\
\text { likely to lead to } \\
\text { knowledge } \\
\text { creation when } \\
\text { individuals share } \\
\text { the same field } \\
\text { specialty. } \\
\text { H3a. Knowledge } \\
\text { sharing is less } \\
\text { likely to lead to } \\
\text { knowledge } \\
\text { diffusion when } \\
\text { individuals share } \\
\text { the same field } \\
\text { specialty. }\end{array}$ \\
\hline $\begin{array}{l}\text { Intellectual } \\
\text { similarity }\end{array}$ & $\begin{array}{l}\text { Individuals who } \\
\text { are more } \\
\text { intellectually } \\
\text { similar share } \\
\text { more research } \\
\text { topics and } \\
\text { interests in } \\
\text { common. }\end{array}$ & $\begin{array}{l}\text { Inverted U-shape } \\
\text { relationship with } \\
\text { intellectual } \\
\text { similarity. } \\
\text { Individuals with } \\
\text { moderate } \\
\text { intellectual } \\
\text { similarity share } \\
\text { some common } \\
\text { topics/interests to } \\
\text { facilitate mutual } \\
\text { understanding } \\
\text { but also have } \\
\text { unique } \\
\text { knowledge that } \\
\text { can be } \\
\text { transferred. }\end{array}$ & $\begin{array}{l}\text { Inverted U-shape } \\
\text { relationship with } \\
\text { intellectual } \\
\text { similarity. } \\
\text { Individuals with } \\
\text { moderate } \\
\text { intellectual } \\
\text { similarity share } \\
\text { some common } \\
\text { research } \\
\text { topics/interests to } \\
\text { facilitate mutual } \\
\text { understanding } \\
\text { but also have } \\
\text { non-overlapping } \\
\text { interests and } \\
\text { skills that } \\
\text { facilitate } \\
\text { complementaritie } \\
\text { s and synergies } \\
\text { from } \\
\text { collaboration. }\end{array}$ & $\begin{array}{l}\text { Negative effect } \\
\text { with increasing } \\
\text { intellectual } \\
\text { similarity. } \\
\text { Competition for } \\
\text { scarce resources } \\
\text { means that } \\
\text { individuals are } \\
\text { disincentivized } \\
\text { from } \\
\text { acknowledging } \\
\text { their peers, who } \\
\text { compete for } \\
\text { recognition and } \\
\text { rewards, and this } \\
\text { increases with } \\
\text { intellectual } \\
\text { similarity. }\end{array}$ & $\begin{array}{l}\text { H1b. Intellectual } \\
\text { similarity has an } \\
\text { inverted U- } \\
\text { shaped effect on } \\
\text { the relationship } \\
\text { between } \\
\text { knowledge } \\
\text { sharing and } \\
\text { knowledge } \\
\text { transfer. } \\
\text { H2b. Intellectual } \\
\text { similarity has an } \\
\text { inverted U- } \\
\text { shaped effect on } \\
\text { the relationship } \\
\text { between } \\
\text { knowledge } \\
\text { sharing and } \\
\text { knowledge } \\
\text { creation. }\end{array}$ \\
\hline
\end{tabular}




\begin{tabular}{|c|c|c|c|}
\hline & & $\begin{array}{l}\text { When } \\
\text { individuals have } \\
\text { too much } \\
\text { intellectual } \\
\text { similarity, they } \\
\text { become } \\
\text { substitutes and } \\
\text { collaboration } \\
\text { returns minimal } \\
\text { benefits. }\end{array}$ & $\begin{array}{l}\text { H3b. Knowledge } \\
\text { sharing is less } \\
\text { likely to lead to } \\
\text { knowledge } \\
\text { diffusion as the } \\
\text { intellectual } \\
\text { similarity } \\
\text { between } \\
\text { individuals } \\
\text { increases. }\end{array}$ \\
\hline $\begin{array}{l}\text { Elemental } \\
\text { collaboration }\end{array}$ & $\begin{array}{l}\text { Individuals who } \\
\text { have initiated an } \\
\text { elemental } \\
\text { collaboration } \\
\text { have more } \\
\text { information, } \\
\text { trust, and } \\
\text { familiarity with } \\
\text { each other. }\end{array}$ & $\begin{array}{l}\text { Positive effect of } \\
\text { elemental } \\
\text { collaboration. } \\
\text { Individuals who } \\
\text { have formed an } \\
\text { elemental } \\
\text { collaboration } \\
\text { have overcome } \\
\text { the search costs } \\
\text { of finding a } \\
\text { suitable } \\
\text { collaborator and } \\
\text { have already } \\
\text { incurred some } \\
\text { coordination } \\
\text { costs of working } \\
\text { together to } \\
\text { develop an initial } \\
\text { idea/concept. }\end{array}$ & $\begin{array}{l}\text { H2c. } \\
\text { Knowledge- } \\
\text { sharing partners } \\
\text { are more likely } \\
\text { to persist in } \\
\text { knowledge } \\
\text { creation when } \\
\text { individuals share } \\
\text { an existing } \\
\text { elemental } \\
\text { collaboration. }\end{array}$ \\
\hline
\end{tabular}


Table 2. Summary of Randomization Statistics for the Main Dyad-Level Variables by Symposium Night and Room

\begin{tabular}{|c|c|c|c|c|c|c|}
\hline & \multicolumn{3}{|c|}{ Symposium Night } & \multicolumn{3}{|c|}{ Breakout Room } \\
\hline & Same night & Diff. night & Difference & Same room & Diff. room & Difference \\
\hline $\begin{array}{l}\text { Intellectual } \\
\text { similarity }\end{array}$ & 1.076 & 1.078 & -0.002 & 1.066 & 1.080 & -0.014 \\
\hline $\begin{array}{l}\text { Grant co- } \\
\text { applicant }\end{array}$ & 0.002 & 0.002 & 0.000 & 0.002 & 0.002 & 0.001 \\
\hline Prior co-author & 0.002 & 0.002 & 0.000 & 0.001 & 0.002 & -0.001 \\
\hline $\begin{array}{l}\text { Geographic } \\
\text { distance }\end{array}$ & 4.048 & 3.969 & $0.078^{*}$ & 3.992 & 4.068 & -0.077 \\
\hline Same institution & 0.186 & 0.193 & $-0.006^{*}$ & 0.179 & 0.189 & -0.001 \\
\hline $\begin{array}{l}\text { Same } \\
\text { department }\end{array}$ & 0.099 & 0.093 & $0.006^{*}$ & 0.102 & 0.097 & 0.005 \\
\hline $\begin{array}{l}\text { Same field } \\
\text { specialty }\end{array}$ & 0.128 & 0.131 & -0.004 & 0.126 & 0.128 & -0.002 \\
\hline $\begin{array}{l}\text { Same imaging } \\
\text { modality }\end{array}$ & 0.172 & 0.172 & 0.000 & 0.175 & 0.171 & 0.003 \\
\hline Both clinicians & 0.337 & 0.338 & -0.001 & 0.343 & 0.335 & 0.001 \\
\hline Both imagers & 0.173 & 0.175 & -0.001 & 0.170 & 0.175 & -0.005 \\
\hline Same rank & 0.214 & 0.210 & 0.003 & 0.202 & 0.218 & $-0.016 * *$ \\
\hline Both females & 0.0837 & 0.0869 & -0.003 & 0.084 & 0.084 & -0.000 \\
\hline Both males & 0.499 & 0.497 & 0.001 & 0.506 & 0.496 & 0.010 \\
\hline Prior citations & 0.022 & 0.023 & -0.000 & 0.022 & 0.022 & 0.000 \\
\hline $\begin{array}{l}\text { Prior MeSH } \\
\text { keywords }\end{array}$ & 369.897 & 371.480 & -1.583 & 371.393 & 369.355 & 2.038 \\
\hline Super expert & 0.070 & 0.069 & 0.001 & 0.066 & 0.072 & -0.005 \\
\hline Rank difference & 1.865 & 1.866 & -0.002 & 1.901 & 1.849 & $0.0593^{* *}$ \\
\hline Observations & 15,817 & 30,848 & 46,665 & 4,206 & 11,611 & 15,817 \\
\hline
\end{tabular}

$\mathrm{N}=15,817$. Two-tailed t-tests show that randomization achieved balance across covariates, aside from two marginally significant differences, with regard to assignment of same rank pairs to same vs. different breakout rooms. * $p<0.10$; ** $p<0.05 ; * * * p<0.01$ 
Table 3. Descriptive Statistics for the Dyad-Level Variables by Communicating vs. Non-Communicating Pairs

\begin{tabular}{|l|l|l|l|l|l|l|l|l|l|l|l|}
\hline & $\begin{array}{l}\text { Same } \\
\text { room }\end{array}$ & $\begin{array}{l}\text { Prior co- } \\
\text { author }\end{array}$ & $\begin{array}{l}\text { Same } \\
\text { institution }\end{array}$ & $\begin{array}{l}\text { Same } \\
\text { dept. }\end{array}$ & $\begin{array}{l}\text { Both } \\
\text { imagers }\end{array}$ & $\begin{array}{l}\text { Both } \\
\text { clinicians }\end{array}$ & $\begin{array}{l}\text { Same } \\
\text { clinical } \\
\text { area }\end{array}$ & $\begin{array}{l}\text { Same } \\
\text { imaging } \\
\text { modality }\end{array}$ & $\begin{array}{l}\text { Same } \\
\text { rank }\end{array}$ & $\begin{array}{l}\text { Both } \\
\text { female }\end{array}$ & $\begin{array}{l}\text { Both } \\
\text { male }\end{array}$ \\
\hline Comm. dyad & 0.167 & 0.353 & 0.108 & 0.153 & 0.083 & 0.083 & 0.108 & 0.100 & 0.083 & 0.104 & 0.079 \\
\hline Non-comm. dyad & 0.046 & 0.078 & 0.071 & 0.0697 & 0.077 & 0.076 & 0.073 & 0.073 & 0.0765 & 0.076 & 0.077 \\
\hline Difference & $0.120^{* * *}$ & $0.275^{* * *}$ & $0.037^{* * *}$ & $0.084^{* *}$ & 0.006 & 0.007 & $0.035^{* * *}$ & $0.027^{* * *}$ & 0.007 & $0.029^{* *}$ & 0.002 \\
\hline
\end{tabular}

$\mathrm{N}=15,817$. Two-tailed tests show that distribution of shared dyad-level variables differ significantly between communicating and non-communicating pairs. $* p<0.10 ; * * p<0.05 ; * * * p<0.01$. 
Table 4. Correlation Matrix for Dyad-Level Variables

\begin{tabular}{|c|c|c|c|c|c|c|c|c|c|c|c|}
\hline & Variable & Mean & SD & 1 & 2 & 3 & 4 & 5 & 6 & 7 & 8 \\
\hline 1 & Same room & 0.266 & 0.442 & 1 & & & & & & & \\
\hline 2 & F2F comm. & 0.078 & 0.268 & $0.0865^{* *}$ & 1 & & & & & & \\
\hline 3 & Intellectual similarity & 1.076 & 0.810 & -0.0053 & $0.0165 * *$ & 1 & & & & & \\
\hline 4 & Grant co-applicant & 0.002 & 0.044 & $0.0088 * *$ & $0.0276 * *$ & $0.0200 * *$ & 1 & & & & \\
\hline 5 & Prior co-author & 0.002 & 0.042 & $-0.0089 * *$ & $0.0209 * *$ & $0.0442^{* *}$ & $0.0929 * *$ & 1 & & & \\
\hline 6 & Geographic distance & 4.048 & 4.312 & -0.003 & -0.0012 & $0.0115^{* *}$ & $-0.0256 * *$ & $-0.0216 * *$ & 1 & & \\
\hline 7 & Same institution & 0.186 & 0.389 & -0.006 & $0.0169 * *$ & $0.0537 * *$ & $0.0485^{* *}$ & $0.0445 * *$ & $-0.3356 * *$ & 1 & \\
\hline 8 & Same department & 0.099 & 0.298 & 0.0023 & $0.0367 * *$ & $0.1231^{* *}$ & $0.0484 * *$ & $0.0586 * *$ & $-0.0074 * *$ & $0.1365 * *$ & 1 \\
\hline 9 & Same field specialty & 0.128 & 0.334 & $0.0092 * *$ & $0.0186^{* *}$ & $0.0342 * *$ & $0.0312^{* *}$ & $0.0308^{* *}$ & $-0.0125 * *$ & $0.0359 * *$ & $0.1218 * *$ \\
\hline 10 & Same imaging modality & 0.172 & 0.378 & -0.0029 & $0.0177^{* *}$ & $-0.0098 * *$ & $0.0103 * *$ & $0.0176^{* *}$ & $-0.0489 * *$ & $0.0134 * *$ & $0.0290 * *$ \\
\hline 11 & Both clinicians & 0.337 & 0.473 & -0.0031 & $0.0073 * *$ & $-0.0453 * *$ & $-0.0212 * *$ & $-0.0130 * *$ & $-0.0236 * *$ & $-0.0435 * *$ & $-0.0957 * *$ \\
\hline 12 & Both imagers & 0.173 & 0.379 & 0.0002 & 0.0012 & $0.0816^{* *}$ & $0.0248 * *$ & $0.0265 * *$ & $0.0097 * *$ & $0.0486 * *$ & $0.3036 * *$ \\
\hline 13 & Same rank & 0.214 & 0.410 & -0.0045 & $0.0070 * *$ & $0.0165 * *$ & 0.0066 & 0.0046 & $-0.0085 * *$ & $0.0235 * *$ & $0.0148^{* *}$ \\
\hline 14 & Both females & 0.084 & 0.277 & -0.0029 & $0.0122 * *$ & $-0.0267 * *$ & -0.005 & -0.0045 & $0.0628 * *$ & $-0.0159 * *$ & $-0.0129 * *$ \\
\hline 15 & Both males & 0.499 & 0.500 & 0.0037 & 0.0006 & $0.0505^{* *}$ & $0.0076^{* *}$ & $0.0099 * *$ & $-0.0825 * *$ & $0.0187 * *$ & $0.0254 * *$ \\
\hline 16 & Super expert & 0.070 & 0.256 & 0.0061 & $-0.0142 * *$ & $0.0938 * *$ & $0.0348 * *$ & $0.0149 * *$ & $-0.0404 * *$ & $0.0341^{* *}$ & $0.1112 * *$ \\
\hline 17 & Prior citations & 0.022 & 0.148 & 0.0057 & $0.0261 * *$ & $0.0922^{* *}$ & $0.0337 * *$ & $0.1375^{* *}$ & $0.0069 * *$ & $0.0270^{* *}$ & $0.0661 * *$ \\
\hline 18 & Prior MeSH keywords & 369.897 & 371.728 & 0.0002 & $0.0080 * *$ & $0.6753 * *$ & $0.0106 * *$ & $0.0473 * *$ & $-0.0288 * *$ & $0.0345^{* *}$ & $0.0389 * *$ \\
\hline 19 & Different rank & 1.864 & 1.503 & $0.0070 * *$ & $-0.0084 * *$ & $-0.1053 * *$ & $-0.0141 * *$ & $-0.0177 * *$ & -0.0064 & $-0.0541 * *$ & $-0.0396 * *$ \\
\hline
\end{tabular}




\begin{tabular}{|c|c|c|c|c|c|c|c|c|c|c|c|}
\hline & Variable & 9 & 10 & 11 & 12 & 13 & 14 & 15 & 16 & 17 & 18 \\
\hline 9 & Same field specialty & 1 & & & & & & & & & \\
\hline 10 & Same imaging modality & $0.0510^{* *}$ & 1 & & & & & & & & \\
\hline 11 & Both clinicians & $-0.0301 * *$ & $0.0141^{* *}$ & 1 & & & & & & & \\
\hline 12 & Both imagers & $0.0588^{* *}$ & -0.0001 & $-0.3290 * *$ & 1 & & & & & & \\
\hline 13 & Same rank & -0.0014 & $0.0099 * *$ & $0.0077 * *$ & $-0.0077 * *$ & 1 & & & & & \\
\hline 14 & Both females & $0.0111^{* *}$ & $0.0111^{* *}$ & $0.0879 * *$ & $-0.0649 * *$ & $0.0147 * *$ & 1 & & & & \\
\hline 15 & Both males & $0.0124^{* *}$ & $-0.0080 * *$ & $-0.1064 * *$ & $0.1044^{* *}$ & $-0.0186 * *$ & $-0.3044 * *$ & 1 & & & \\
\hline 16 & Super expert & $0.0600^{* *}$ & $-0.0905 * *$ & $-0.2233^{* *}$ & $0.1789 * *$ & 0.0054 & $-0.0620 * *$ & $0.0810^{* *}$ & 1 & & \\
\hline 17 & Prior citations & $0.0153^{* *}$ & -0.0034 & $-0.0253 * *$ & $0.0385 * *$ & $0.0106^{* *}$ & -0.0046 & $0.0138 * *$ & $0.0437 * *$ & 1 & \\
\hline 18 & Common MeSH terms & $-0.0118^{* *}$ & $-0.0122 * *$ & $-0.0411^{* *}$ & $0.0382 * *$ & $-0.0594 * *$ & $-0.0675 * *$ & $0.0948^{* *}$ & $0.0765^{* *}$ & $0.0964^{* *}$ & 1 \\
\hline 19 & Different rank & -0.0019 & -0.0015 & $-0.0162 * *$ & $0.0163^{* *}$ & $-0.6372 * *$ & $-0.0171^{* *}$ & $0.0223 * *$ & $-0.0091^{* *}$ & $-0.0372 * *$ & $0.0381^{* *}$ \\
\hline
\end{tabular}


Table 5. Relationships Between Knowledge Sharing and Knowledge Transfer

\begin{tabular}{|c|c|c|c|c|c|c|c|c|}
\hline \multicolumn{9}{|c|}{ Effects from Regression Analysis of Knowledge Transfer (15,817 Dyads) } \\
\hline Variable & $\begin{array}{c}\text { Model } 1 \\
\text { OLS }\end{array}$ & $\begin{array}{c}\text { Model } 2 \\
\text { 2sls }\end{array}$ & $\begin{array}{l}\text { Model } 3 \\
\text { OLS }\end{array}$ & $\begin{array}{c}\text { Model } 4 \\
\text { 2sls }\end{array}$ & $\begin{array}{c}\text { Model } 5 \\
\text { OLS }\end{array}$ & $\begin{array}{c}\text { Model } 6 \\
\text { 2sls }\end{array}$ & $\begin{array}{c}\text { Model } 7 \\
\text { OLS }\end{array}$ & $\begin{array}{c}\text { Model } 8 \\
\text { 2sls }\end{array}$ \\
\hline Same room & $\begin{array}{c}0.164 * \\
(0.0864)\end{array}$ & & $\begin{array}{l}0.0574 \\
(0.125)\end{array}$ & & $\begin{array}{l}0.0429 \\
(0.108)\end{array}$ & & $\begin{array}{c}-0.0596 \\
(0.136)\end{array}$ & \\
\hline F2F communication & & $\begin{array}{l}1.292 * \\
(0.675)\end{array}$ & & $\begin{array}{c}0.330 \\
(0.955)\end{array}$ & & $\begin{array}{c}0.285 \\
(0.795)\end{array}$ & & $\begin{array}{l}-0.802 \\
(1.072)\end{array}$ \\
\hline Same room x Same field specialty & & & $\begin{array}{l}-0.123 \\
(0.126)\end{array}$ & & & & $\begin{array}{l}-0.118 \\
(0.126)\end{array}$ & \\
\hline F2F comm. x Same field specialty & & & & $\begin{array}{c}1.103 \\
(1.021)\end{array}$ & & & & $\begin{array}{c}1.248 \\
(1.055)\end{array}$ \\
\hline Same room x Low intellectual similarity & & & & & $\begin{array}{c}-0.0367 \\
(0.151)\end{array}$ & & $\begin{array}{c}-0.0379 \\
(0.151)\end{array}$ & \\
\hline Same room x Moderate intellectual similarity & & & & & $\begin{array}{c}0.387 * * * \\
(0.142)\end{array}$ & & $\begin{array}{c}0.386^{* * *} \\
(0.142)\end{array}$ & \\
\hline F2F comm. $x$ Low intellectual similarity & & & & & & $\begin{array}{l}-0.287 \\
(1.216)\end{array}$ & & $\begin{array}{l}-0.309 \\
(1.269)\end{array}$ \\
\hline F2F comm. $x$ Moderate intellectual similarity & & & & & & $\begin{array}{c}3.608 * * * \\
(1.278)\end{array}$ & & $\begin{array}{c}3.624 * * * \\
(1.343)\end{array}$ \\
\hline Same field specialty & $\begin{array}{r}-0.0178 \\
(0.114)\end{array}$ & $\begin{array}{c}-0.0526 \\
(0.112)\end{array}$ & $\begin{array}{l}0.0146 \\
(0.123)\end{array}$ & $\begin{array}{l}0.0610 \\
(0.162)\end{array}$ & $\begin{array}{r}-0.0191 \\
(0.114)\end{array}$ & $\begin{array}{c}-0.0543 \\
(0.113)\end{array}$ & $\begin{array}{l}0.0122 \\
(0.123)\end{array}$ & $\begin{array}{l}0.0741 \\
(0.169)\end{array}$ \\
\hline Low intellectual similarity (vs. High) & $\begin{array}{c}-1.581 * * * \\
(0.282)\end{array}$ & $\begin{array}{c}-1.567 * * * \\
(0.282)\end{array}$ & $\begin{array}{c}-1.581 * * * \\
(0.282)\end{array}$ & $\begin{array}{c}-1.574 * * * \\
(0.284)\end{array}$ & $\begin{array}{c}-1.573 * * * \\
(0.286)\end{array}$ & $\begin{array}{c}-1.569 * * * \\
(0.303)\end{array}$ & $\begin{array}{c}-1.572^{* * *} \\
(0.286)\end{array}$ & $\begin{array}{c}-1.576^{* * *} \\
(0.311)\end{array}$ \\
\hline Moderate intellectual similarity (vs. High) & $\begin{array}{c}0.454^{* * *} \\
(0.145)\end{array}$ & $\begin{array}{c}0.478^{* * *} \\
(0.147)\end{array}$ & $\begin{array}{c}0.454^{* * *} \\
(0.145)\end{array}$ & $\begin{array}{c}2.048 * * * \\
(0.212)\end{array}$ & $\begin{array}{c}0.351^{* *} \\
(0.146)\end{array}$ & $\begin{array}{c}1.781^{* * *} \\
(0.229)\end{array}$ & $\begin{array}{c}0.352 * * \\
(0.146)\end{array}$ & $\begin{array}{c}1.783^{* * *} \\
(0.234)\end{array}$ \\
\hline Post co-author & $\begin{array}{r}-0.0510 \\
(0.330)\end{array}$ & & $\begin{array}{r}-0.0532 \\
(0.330)\end{array}$ & & $\begin{array}{l}-0.0610 \\
(0.330)\end{array}$ & & $\begin{array}{l}-0.0632 \\
(0.330)\end{array}$ & \\
\hline Grant co-applicant & $\begin{array}{l}-0.107 \\
(0.619)\end{array}$ & & $\begin{array}{r}-0.0982 \\
(0.619)\end{array}$ & & $\begin{array}{l}-0.105 \\
(0.620)\end{array}$ & & $\begin{array}{r}-0.0971 \\
(0.620)\end{array}$ & \\
\hline Prior co-author & $\begin{array}{l}-1.248 \\
(0.867)\end{array}$ & $\begin{array}{c}-1.617^{*} \\
(0.896)\end{array}$ & $\begin{array}{l}-1.257 \\
(0.866)\end{array}$ & $\begin{array}{c}-1.588 * \\
(0.933)\end{array}$ & $\begin{array}{l}-1.250 \\
(0.868)\end{array}$ & $\begin{array}{c}-1.567^{*} \\
(0.933)\end{array}$ & $\begin{array}{l}-1.259 \\
(0.866)\end{array}$ & $\begin{array}{l}-1.536 \\
(0.995)\end{array}$ \\
\hline Constant & $\begin{array}{c}2.920 * * * \\
(0.483)\end{array}$ & $\begin{array}{c}2.859 * * * \\
(0.490)\end{array}$ & $\begin{array}{c}2.950 * * * \\
(0.482)\end{array}$ & $\begin{array}{c}1.303^{* * *} \\
(0.411)\end{array}$ & $\begin{array}{c}2.915^{* * *} \\
(0.483)\end{array}$ & $\begin{array}{c}1.189 * * * \\
(0.409)\end{array}$ & $\begin{array}{c}2.945^{* * *} \\
(0.483)\end{array}$ & $\begin{array}{c}1.281^{* * *} \\
(0.424)\end{array}$ \\
\hline Controls: & & & & & & & & \\
\hline Shared dyad characteristics & $\mathrm{Y}$ & $\mathrm{Y}$ & $\mathrm{Y}$ & $\mathrm{Y}$ & $\mathrm{Y}$ & $\mathrm{Y}$ & $\mathrm{Y}$ & $\mathrm{Y}$ \\
\hline Prior MeSH keywords & $\mathrm{Y}$ & $\mathrm{Y}$ & $\mathrm{Y}$ & $\mathrm{Y}$ & $\mathrm{Y}$ & $\mathrm{Y}$ & $\mathrm{Y}$ & $\mathrm{Y}$ \\
\hline Prior citations & $\mathrm{Y}$ & $\mathrm{Y}$ & $\mathrm{Y}$ & $\mathrm{Y}$ & $\mathrm{Y}$ & $\mathrm{Y}$ & $\mathrm{Y}$ & $\mathrm{Y}$ \\
\hline Career experience & $\mathrm{Y}$ & $\mathrm{Y}$ & $\mathrm{Y}$ & $\mathrm{Y}$ & $\mathrm{Y}$ & $\mathrm{Y}$ & $\mathrm{Y}$ & $\mathrm{Y}$ \\
\hline Night FE & $\mathrm{Y}$ & $\mathrm{Y}$ & $\mathrm{Y}$ & $\mathrm{Y}$ & $\mathrm{Y}$ & $\mathrm{Y}$ & $\mathrm{Y}$ & $\mathrm{Y}$ \\
\hline Room FE & $\mathrm{Y}$ & $\mathrm{Y}$ & $\mathrm{Y}$ & $\mathrm{Y}$ & $\mathrm{Y}$ & $\mathrm{Y}$ & $\mathrm{Y}$ & $\mathrm{Y}$ \\
\hline Observations & 15,817 & 15,817 & 15,817 & 15,817 & 15,817 & 15,817 & 15,817 & 15,817 \\
\hline R-squared & 0.326 & 0.318 & 0.326 & 0.317 & 0.327 & 0.303 & 0.327 & 0.322 \\
\hline
\end{tabular}

Two-way robust standard errors in parentheses

$* * * \mathrm{p}<0.01, * * \mathrm{p}<0.05,{ }^{*} \mathrm{p}<0.1$ 
Table 6. Relationships Between Knowledge Sharing and Knowledge Creation

\begin{tabular}{|c|c|c|c|c|c|c|c|c|c|}
\hline \multicolumn{10}{|c|}{ Effects from Regression Analysis of Knowledge Creation (15,817 Dyads) } \\
\hline Variable & $\begin{array}{c}\text { Model } 1 \\
\text { OLS }\end{array}$ & $\begin{array}{c}\text { Model } 2 \\
\text { 2sls }\end{array}$ & $\begin{array}{c}\text { Model } 3 \\
\text { OLS }\end{array}$ & $\begin{array}{c}\text { Model } 4 \\
\text { 2sls }\end{array}$ & $\begin{array}{c}\text { Model } 5 \\
\text { OLS }\end{array}$ & $\begin{array}{c}\text { Model } 6 \\
\text { 2sls }\end{array}$ & $\begin{array}{c}\text { Model } 7 \\
\text { OLS }\end{array}$ & $\begin{array}{c}\text { Model } 8 \\
\text { 2sls }\end{array}$ & $\begin{array}{c}\text { Model } 9 \\
\text { OLS }\end{array}$ \\
\hline Same room & $\begin{array}{l}0.00345 \\
(0.0145)\end{array}$ & & $\begin{array}{c}-0.0851 \\
(0.0538)\end{array}$ & & $\begin{array}{c}-0.0111 \\
(0.0320)\end{array}$ & & $\begin{array}{c}-0.0985 \\
(0.0670)\end{array}$ & & $\begin{array}{l}-0.0985 \\
(0.0670)\end{array}$ \\
\hline F2F communication & & $\begin{array}{l}0.0376 \\
(0.111)\end{array}$ & & $\begin{array}{c}-0.598 \\
(0.440)\end{array}$ & & $\begin{array}{c}-0.0589 \\
(0.236)\end{array}$ & & $\begin{array}{l}-0.699 \\
(0.538)\end{array}$ & \\
\hline Same room x Same field specialty & & & $\begin{array}{l}-0.101 * \\
(0.0571)\end{array}$ & & & & $\begin{array}{l}-0.101^{*} \\
(0.0567)\end{array}$ & & $\begin{array}{l}-0.101 * \\
(0.0567)\end{array}$ \\
\hline F2F comm. x Same field specialty & & & & $\begin{array}{c}-0.729 \\
(0.468)\end{array}$ & & & & $\begin{array}{c}-0.735 \\
(0.470)\end{array}$ & \\
\hline Same room $x$ Low intellectual similarity & & & & & $\begin{array}{c}0.0155 \\
(0.0305)\end{array}$ & & $\begin{array}{c}0.0145 \\
(0.0302)\end{array}$ & & $\begin{array}{c}0.0144 \\
(0.0302)\end{array}$ \\
\hline Same room x Moderate intellectual similarity & & & & & $\begin{array}{c}0.0297 \\
(0.0317)\end{array}$ & & $\begin{array}{c}0.0286 \\
(0.0315)\end{array}$ & & $\begin{array}{c}0.0286 \\
(0.0315)\end{array}$ \\
\hline F2F comm. $x$ Low intellectual similarity & & & & & & $\begin{array}{c}0.0852 \\
(0.238)\end{array}$ & & $\begin{array}{c}0.0722 \\
(0.239)\end{array}$ & \\
\hline F2F comm. x Moderate intellectual similarity & & & & & & $\begin{array}{c}0.241 \\
(0.249)\end{array}$ & & $\begin{array}{c}0.251 \\
(0.256)\end{array}$ & \\
\hline Same field specialty & $\begin{array}{c}0.0599 \\
(0.0380)\end{array}$ & $\begin{array}{l}0.0640 * \\
(0.0386)\end{array}$ & $\begin{array}{l}0.0868 * \\
(0.0517)\end{array}$ & $\begin{array}{c}0.139 * \\
(0.0836)\end{array}$ & $\begin{array}{c}0.0598 \\
(0.0380)\end{array}$ & $\begin{array}{c}0.0643 \\
(0.0393)\end{array}$ & $\begin{array}{l}0.0866 * \\
(0.0516)\end{array}$ & $\begin{array}{c}0.140 * \\
(0.0842)\end{array}$ & $\begin{array}{l}0.0865 * \\
(0.0515)\end{array}$ \\
\hline Low intellectual similarity (vs. High) & $\begin{array}{c}-0.0641^{* *} \\
(0.0323)\end{array}$ & $\begin{array}{c}-0.0636 * * \\
(0.0324)\end{array}$ & $\begin{array}{c}-0.0639 * * \\
(0.0322)\end{array}$ & $\begin{array}{c}-0.0686^{* *} \\
(0.0344)\end{array}$ & $\begin{array}{c}-0.0682 * \\
(0.0367)\end{array}$ & $\begin{array}{l}-0.0723 \\
(0.0476)\end{array}$ & $\begin{array}{c}-0.0677 * \\
(0.0365)\end{array}$ & $\begin{array}{c}-0.0783 \\
(0.0507)\end{array}$ & $\begin{array}{c}-0.0678 * \\
(0.0367)\end{array}$ \\
\hline Moderate intellectual similarity (vs. High) & $\begin{array}{c}-0.0437 * * \\
(0.0194)\end{array}$ & $\begin{array}{c}-0.0444^{* *} \\
(0.0191)\end{array}$ & $\begin{array}{c}-0.0434 * * \\
(0.0193)\end{array}$ & $\begin{array}{c}0.0214 \\
(0.0169)\end{array}$ & $\begin{array}{c}-0.0514^{* *} \\
(0.0237)\end{array}$ & $\begin{array}{l}0.00940 \\
(0.0181)\end{array}$ & $\begin{array}{c}-0.0509 * * \\
(0.0235)\end{array}$ & $\begin{array}{c}0.0101 \\
(0.0188)\end{array}$ & $\begin{array}{c}-0.0508 * * \\
(0.0235)\end{array}$ \\
\hline Grant co-applicant & $\begin{array}{c}1.539 * * \\
(0.765)\end{array}$ & & $\begin{array}{c}1.546 * * \\
(0.764)\end{array}$ & & $\begin{array}{c}1.540 * * \\
(0.765)\end{array}$ & & $\begin{array}{c}1.546 * * \\
(0.763)\end{array}$ & & $\begin{array}{c}1.546 * * \\
(0.763)\end{array}$ \\
\hline Prior co-author & $\begin{array}{c}6.018 * \\
(3.496)\end{array}$ & $\begin{array}{c}6.162 * \\
(3.459)\end{array}$ & $\begin{array}{c}6.010 * \\
(3.493)\end{array}$ & $\begin{array}{c}6.181^{*} \\
(3.484)\end{array}$ & $\begin{array}{c}6.017^{*} \\
(3.495)\end{array}$ & $\begin{array}{c}6.174 * \\
(3.476)\end{array}$ & $\begin{array}{c}6.008 * \\
(3.493)\end{array}$ & $\begin{array}{l}6.192 * \\
(3.501)\end{array}$ & $\begin{array}{l}6.008^{*} \\
(3.493)\end{array}$ \\
\hline Grant awardee & & & & & & & & & $\begin{array}{r}-0.00192 \\
(0.0128)\end{array}$ \\
\hline Constant & $\begin{array}{c}0.0579 \\
(0.0415)\end{array}$ & $\begin{array}{c}0.0577 \\
(0.0424)\end{array}$ & $\begin{array}{c}0.0548 \\
(0.0400)\end{array}$ & $\begin{array}{c}-0.0186 \\
(0.0231)\end{array}$ & $\begin{array}{c}0.0615 \\
(0.0439)\end{array}$ & $\begin{array}{l}-0.00535 \\
(0.0229)\end{array}$ & $\begin{array}{c}0.0582 \\
(0.0424)\end{array}$ & $\begin{array}{c}-0.0244 \\
(0.0235)\end{array}$ & $\begin{array}{c}0.0582 \\
(0.0424)\end{array}$ \\
\hline Controls: & & & & & & & & & \\
\hline Shared dyad characteristics & Y & $\mathrm{Y}$ & $\mathrm{Y}$ & $\mathrm{Y}$ & $\mathrm{Y}$ & $\mathrm{Y}$ & $\mathrm{Y}$ & $\mathrm{Y}$ & $\mathrm{Y}$ \\
\hline Prior MeSH keywords & $\mathrm{Y}$ & $\mathrm{Y}$ & $\mathrm{Y}$ & $\mathrm{Y}$ & $\mathrm{Y}$ & $\mathrm{Y}$ & $\mathrm{Y}$ & $\mathrm{Y}$ & $\mathrm{Y}$ \\
\hline Prior citations & $\mathrm{Y}$ & $\mathrm{Y}$ & $\mathrm{Y}$ & $\mathrm{Y}$ & $\mathrm{Y}$ & $\mathrm{Y}$ & $\mathrm{Y}$ & $\mathrm{Y}$ & $\mathrm{Y}$ \\
\hline Career experience & $\mathrm{Y}$ & $\mathrm{Y}$ & $\mathrm{Y}$ & $\mathrm{Y}$ & $\mathrm{Y}$ & $\mathrm{Y}$ & $\mathrm{Y}$ & $\mathrm{Y}$ & $\mathrm{Y}$ \\
\hline Night FE & $\mathrm{Y}$ & $\mathrm{Y}$ & $\mathrm{Y}$ & $\mathrm{Y}$ & $\mathrm{Y}$ & $\mathrm{Y}$ & $\mathrm{Y}$ & $\mathrm{Y}$ & $\mathrm{Y}$ \\
\hline Room FE & $\mathrm{Y}$ & $\mathrm{Y}$ & $\mathrm{Y}$ & $\mathrm{Y}$ & $\mathrm{Y}$ & $\mathrm{Y}$ & $\mathrm{Y}$ & $\mathrm{Y}$ & $\mathrm{Y}$ \\
\hline Observations & 15,817 & 15,817 & 15,817 & 15,817 & 15,817 & 15,817 & 15,817 & 15,817 & 15,817 \\
\hline R-squared & 0.082 & 0.078 & 0.083 & 0.064 & 0.082 & 0.076 & 0.083 & 0.062 & 0.083 \\
\hline
\end{tabular}

Two-way robust standard errors in parentheses

*** $\mathrm{p}<0.01,{ }^{* *} \mathrm{p}<0.05,{ }^{*} \mathrm{p}<0.1$ 
Table 7. Relationships Between Knowledge Sharing and Knowledge Diffusion

\begin{tabular}{|c|c|c|c|c|c|c|c|c|}
\hline \multicolumn{9}{|c|}{ Effects of Knowledge Sharing on Knowledge Diffusion ( $N=15,817$ dyads) } \\
\hline Variable & $\begin{array}{c}\text { Model } 1 \\
\text { OLS }\end{array}$ & $\begin{array}{c}\text { Model } 2 \\
\text { 2sls }\end{array}$ & $\begin{array}{c}\text { Model } 3 \\
\text { OLS }\end{array}$ & $\begin{array}{c}\text { Model } 4 \\
\text { 2sls }\end{array}$ & $\begin{array}{c}\text { Model } 5 \\
\text { OLS }\end{array}$ & $\begin{array}{c}\text { Model } 6 \\
\text { 2sls }\end{array}$ & $\begin{array}{c}\text { Model } 7 \\
\text { OLS }\end{array}$ & $\begin{array}{c}\text { Model } 8 \\
\text { 2sls }\end{array}$ \\
\hline Same room & $\begin{array}{l}-0.0287 \\
(0.0633)\end{array}$ & & $\begin{array}{c}-0.254 * * \\
(0.121)\end{array}$ & & $\begin{array}{c}0.0111 \\
(0.133)\end{array}$ & & $\begin{array}{c}-0.214 \\
(0.165)\end{array}$ & \\
\hline F2F communication & & $\begin{array}{c}-0.219 \\
(0.507)\end{array}$ & & $\begin{array}{c}-2.185^{* *} \\
(0.985)\end{array}$ & & $\begin{array}{l}-0.0181 \\
(1.014)\end{array}$ & & $\begin{array}{c}-2.008 \\
(1.288)\end{array}$ \\
\hline Same room x Same field specialty & & & $\begin{array}{c}-0.259 * * \\
(0.120)\end{array}$ & & & & $\begin{array}{c}-0.260 * * \\
(0.120)\end{array}$ & \\
\hline F2F comm. x Same field specialty & & & & $\begin{array}{c}-2.253 * * \\
(1.017)\end{array}$ & & & & $\begin{array}{c}-2.284^{* *} \\
(1.040)\end{array}$ \\
\hline Same room $\mathrm{x}$ Low intellectual similarity & & & & & $\begin{array}{l}-0.103 \\
(0.128)\end{array}$ & & $\begin{array}{l}-0.106 \\
(0.128)\end{array}$ & \\
\hline Same room x Moderate intellectual similarity & & & & & $\begin{array}{r}-0.0310 \\
(0.131)\end{array}$ & & $\begin{array}{c}-0.0338 \\
(0.131)\end{array}$ & \\
\hline F2F comm. $x$ Low intellectual similarity & & & & & & $\begin{array}{l}-0.716 \\
(1.029)\end{array}$ & & $\begin{array}{c}-0.757 \\
(1.038)\end{array}$ \\
\hline F2F comm. x Moderate intellectual similarity & & & & & & $\begin{array}{c}-0.00237 \\
(1.032)\end{array}$ & & $\begin{array}{l}0.0275 \\
(1.038)\end{array}$ \\
\hline Same field specialty & $\begin{array}{c}0.181^{*} \\
(0.0956)\end{array}$ & $\begin{array}{c}0.214^{* *} \\
(0.101)\end{array}$ & $\begin{array}{c}0.250^{* *} \\
(0.119)\end{array}$ & $\begin{array}{c}0.446^{* *} \\
(0.188)\end{array}$ & $\begin{array}{c}0.181^{*} \\
(0.0955)\end{array}$ & $\begin{array}{c}0.212^{* *} \\
(0.103)\end{array}$ & $\begin{array}{c}0.250^{* *} \\
(0.118)\end{array}$ & $\begin{array}{c}0.447^{* *} \\
(0.190)\end{array}$ \\
\hline Low intellectual similarity (vs. High) & $\begin{array}{l}-0.184 * \\
(0.0974)\end{array}$ & $\begin{array}{c}-0.253^{* *} \\
(0.105)\end{array}$ & $\begin{array}{l}-0.184^{*} \\
(0.0972)\end{array}$ & $\begin{array}{c}-0.268 * * \\
(0.108)\end{array}$ & $\begin{array}{l}-0.158^{*} \\
(0.0934)\end{array}$ & $\begin{array}{l}-0.194 \\
(0.123)\end{array}$ & $\begin{array}{c}-0.157^{*} \\
(0.0932)\end{array}$ & $\begin{array}{c}-0.206 \\
(0.126)\end{array}$ \\
\hline Moderate intellectual similarity (vs. High) & $\begin{array}{l}-0.105^{*} \\
(0.0532)\end{array}$ & $\begin{array}{c}-0.166^{* * *} \\
(0.0601)\end{array}$ & $\begin{array}{l}-0.104^{*} \\
(0.0531)\end{array}$ & $\begin{array}{c}0.0939 \\
(0.0579)\end{array}$ & $\begin{array}{c}-0.0969 * \\
(0.0546)\end{array}$ & $\begin{array}{c}0.0335 \\
(0.0604)\end{array}$ & $\begin{array}{c}-0.0955^{*} \\
(0.0544)\end{array}$ & $\begin{array}{c}0.0356 \\
(0.0617)\end{array}$ \\
\hline Post co-author & $\begin{array}{c}7.530^{* * *} \\
(1.785)\end{array}$ & & $\begin{array}{c}7.525^{* * *} \\
(1.784)\end{array}$ & & $\begin{array}{c}7.531^{* * *} \\
(1.784)\end{array}$ & & $\begin{array}{c}7.526^{* * *} \\
(1.784)\end{array}$ & \\
\hline Grant co-applicant & $\begin{array}{c}-2.201 \\
(1.381)\end{array}$ & & $\begin{array}{c}-2.184 \\
(1.380)\end{array}$ & & $\begin{array}{c}-2.207 \\
(1.381)\end{array}$ & & $\begin{array}{l}-2.189 \\
(1.380)\end{array}$ & \\
\hline Prior co-author & $\begin{array}{c}6.948 \\
(5.661)\end{array}$ & $\begin{array}{c}10.31 \\
(6.313)\end{array}$ & $\begin{array}{c}6.928 \\
(5.660)\end{array}$ & $\begin{array}{c}10.37 \\
(6.367)\end{array}$ & $\begin{array}{c}6.952 \\
(5.661)\end{array}$ & $\begin{array}{c}10.26 \\
(6.319)\end{array}$ & $\begin{array}{c}6.933 \\
(5.659)\end{array}$ & $\begin{array}{c}10.31 \\
(6.360)\end{array}$ \\
\hline Constant & $\begin{array}{c}0.171 \\
(0.134)\end{array}$ & $\begin{array}{c}0.236 \\
(0.153)\end{array}$ & $\begin{array}{c}0.163 \\
(0.134)\end{array}$ & $\begin{array}{l}-0.0556 \\
(0.116)\end{array}$ & $\begin{array}{c}0.161 \\
(0.138)\end{array}$ & $\begin{array}{l}0.0218 \\
(0.104)\end{array}$ & $\begin{array}{c}0.152 \\
(0.137)\end{array}$ & $\begin{array}{r}-0.0152 \\
(0.108)\end{array}$ \\
\hline Controls: & & & & & & & & \\
\hline Shared dyad characteristics & $\mathrm{Y}$ & $\mathrm{Y}$ & $\mathrm{Y}$ & $Y$ & $Y$ & Y & Y & $\mathrm{Y}$ \\
\hline Prior MeSH keywords & $\mathrm{Y}$ & $\mathrm{Y}$ & $\mathrm{Y}$ & $\mathrm{Y}$ & $\mathrm{Y}$ & $\mathrm{Y}$ & $\mathrm{Y}$ & $\mathrm{Y}$ \\
\hline Prior citations & $\mathrm{Y}$ & $\mathrm{Y}$ & $\mathrm{Y}$ & $\mathrm{Y}$ & $\mathrm{Y}$ & $\mathrm{Y}$ & $\mathrm{Y}$ & $\mathrm{Y}$ \\
\hline Career experience & $\mathrm{Y}$ & $\mathrm{Y}$ & $\mathrm{Y}$ & $\mathrm{Y}$ & $\mathrm{Y}$ & $\mathrm{Y}$ & $\mathrm{Y}$ & $\mathrm{Y}$ \\
\hline Night FE & $\mathrm{Y}$ & $\mathrm{Y}$ & $\mathrm{Y}$ & $\mathrm{Y}$ & $\mathrm{Y}$ & $\mathrm{Y}$ & $\mathrm{Y}$ & $\mathrm{Y}$ \\
\hline Room FE & $\mathrm{Y}$ & $\mathrm{Y}$ & $\mathrm{Y}$ & $\mathrm{Y}$ & $\mathrm{Y}$ & $\mathrm{Y}$ & $\mathrm{Y}$ & $\mathrm{Y}$ \\
\hline Observations & 15,817 & 15,817 & 15,817 & 15,817 & 15,817 & 15,817 & 15,817 & 15,817 \\
\hline R-squared & 0.179 & 0.131 & 0.180 & 0.122 & 0.179 & 0.131 & 0.180 & 0.120 \\
\hline
\end{tabular}

Two-way robust standard errors in parentheses

$* * * \mathrm{p}<0.01, * * \mathrm{p}<0.05,{ }^{*} \mathrm{p}<0.1$ 
Figure 1. Sequence of Events at the Symposium

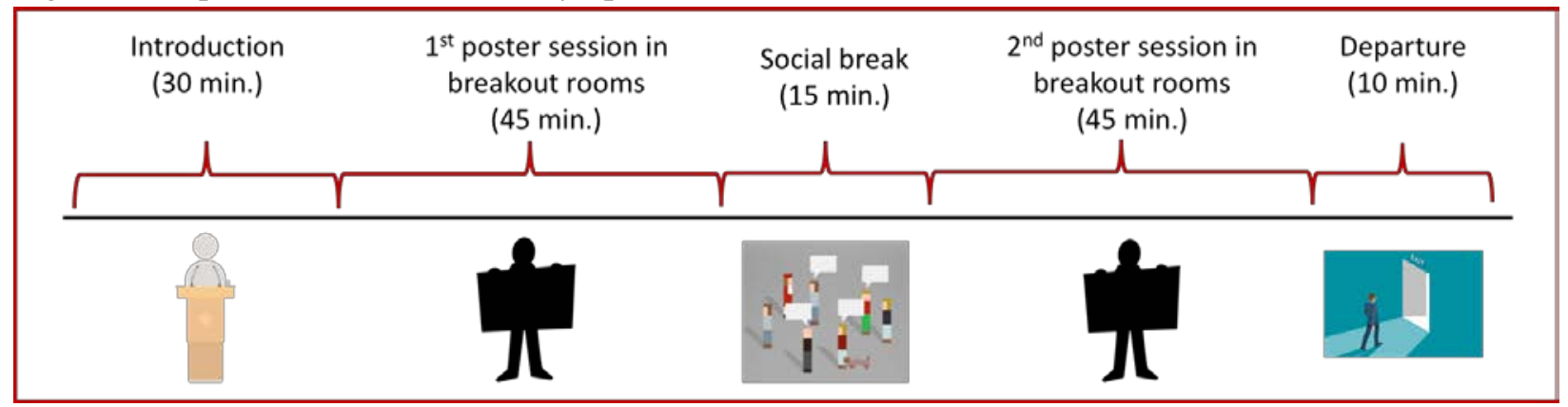

Figure 2. Margins Plot of MeSH Transfer and Intellectual Similarity by Different vs. Same Room Dyads

Predictive Margins of Intellectual Similarity x Same Room with 95\% Cls

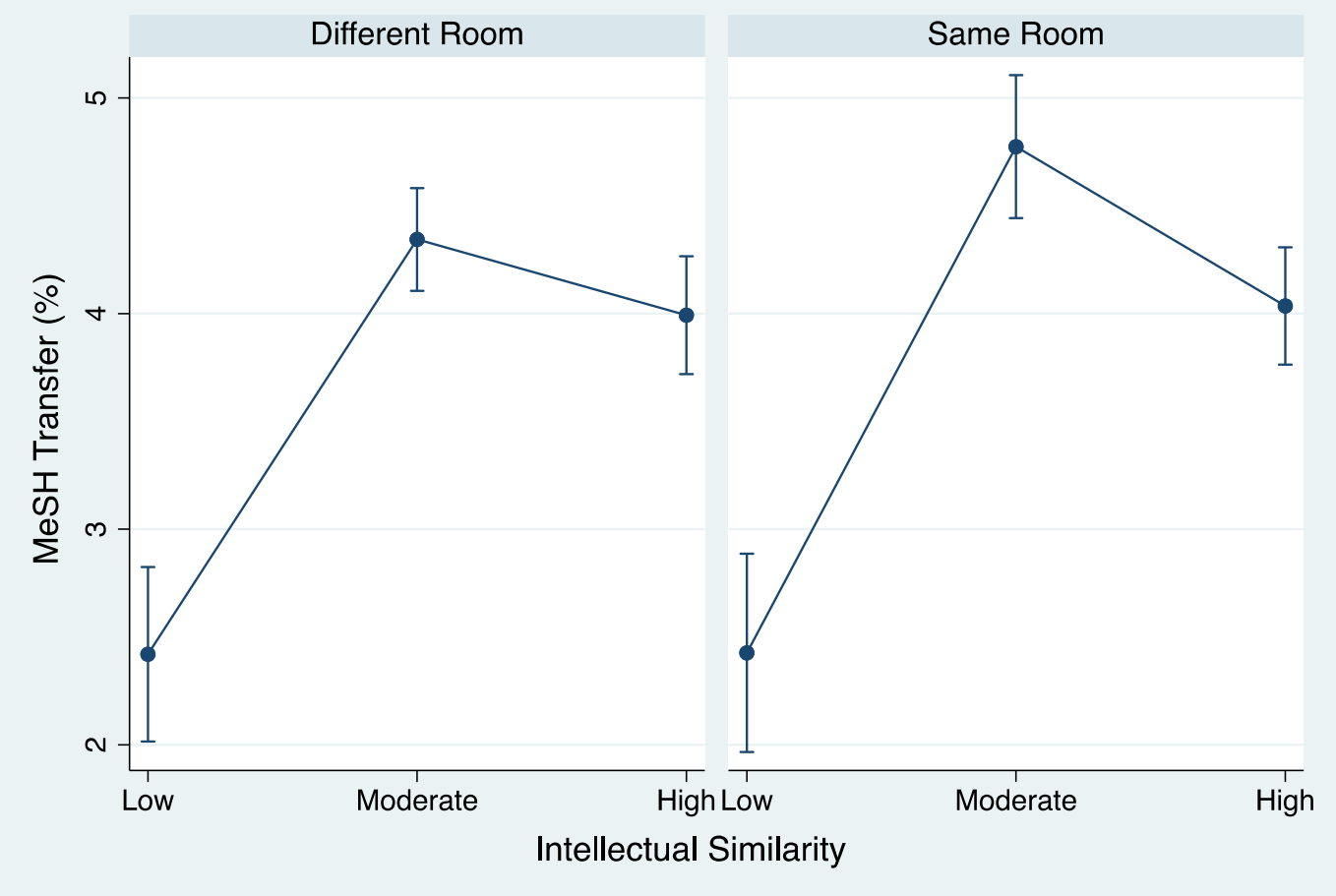


Figure 3. Margins Plot of MeSH Transfer and Intellectual Similarity by Non-Communicating vs. Communicating Dyads

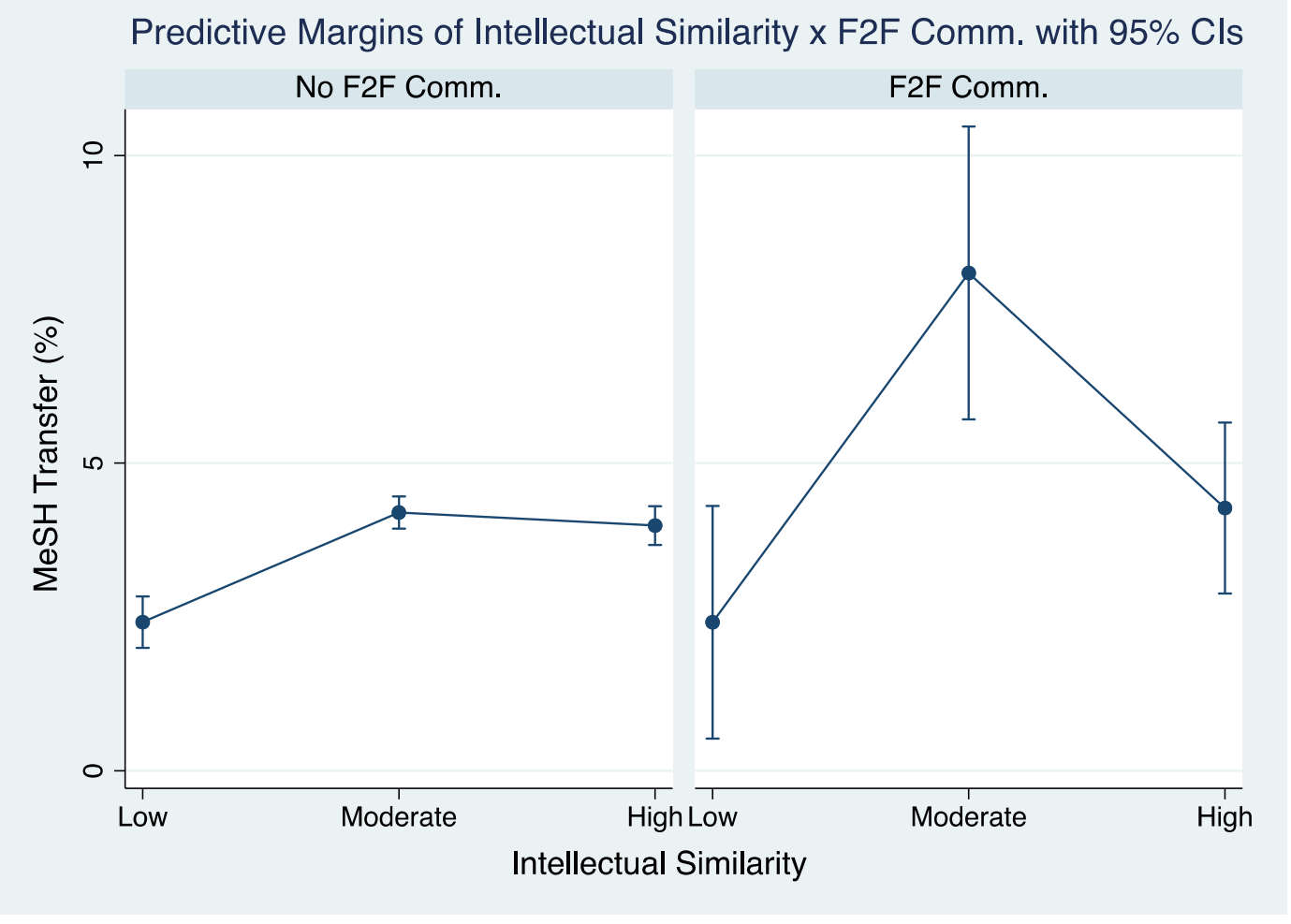

Figure 4. Margins Plot of Co-Publication Count and Field Similarity for Different vs. Same Room Dyads

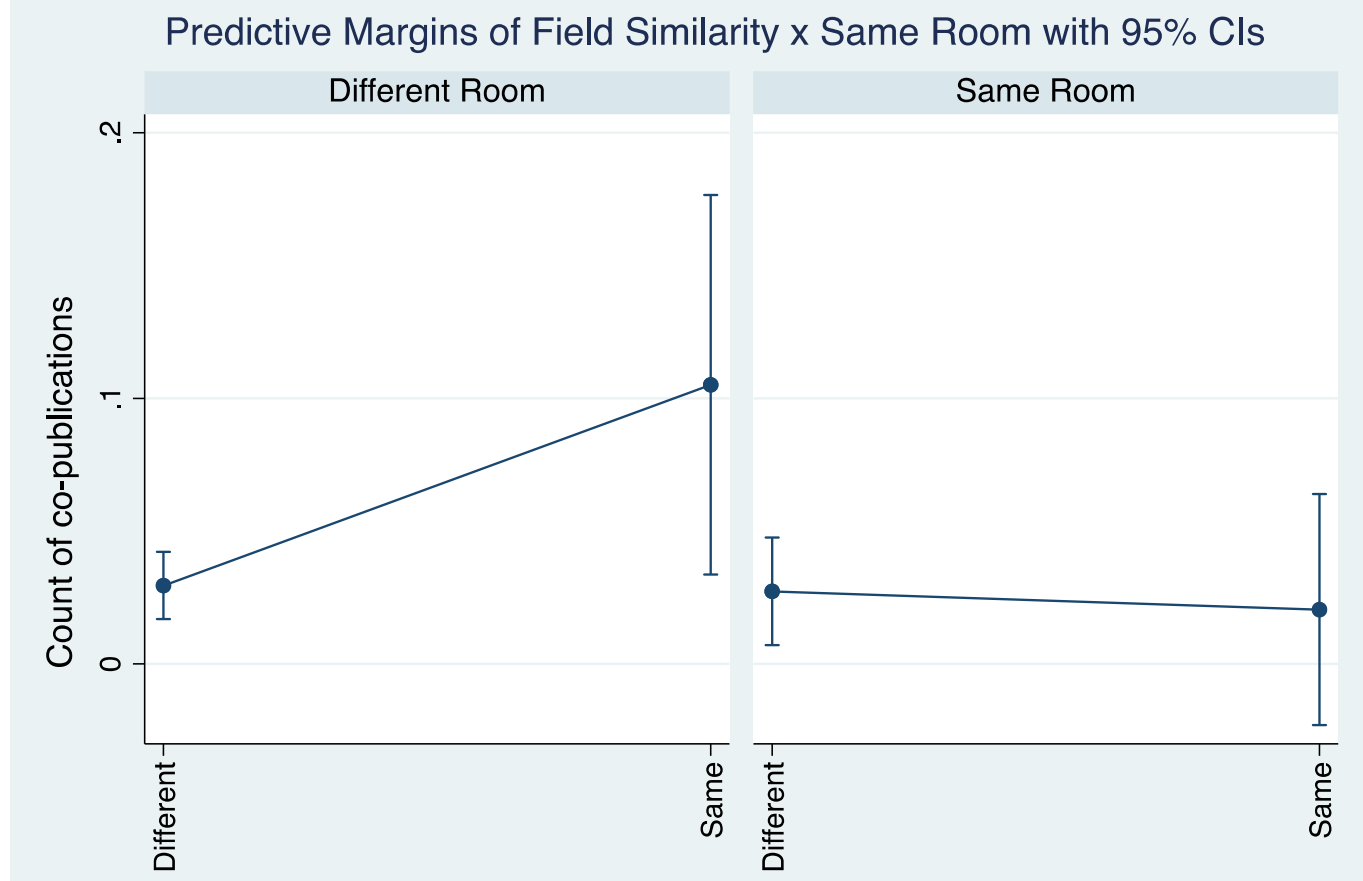

Field Similarity 
Figure 5. Margins Plot of Co-Publication Count and Field Similarity for Communicating vs. NonCommunicating Dyads

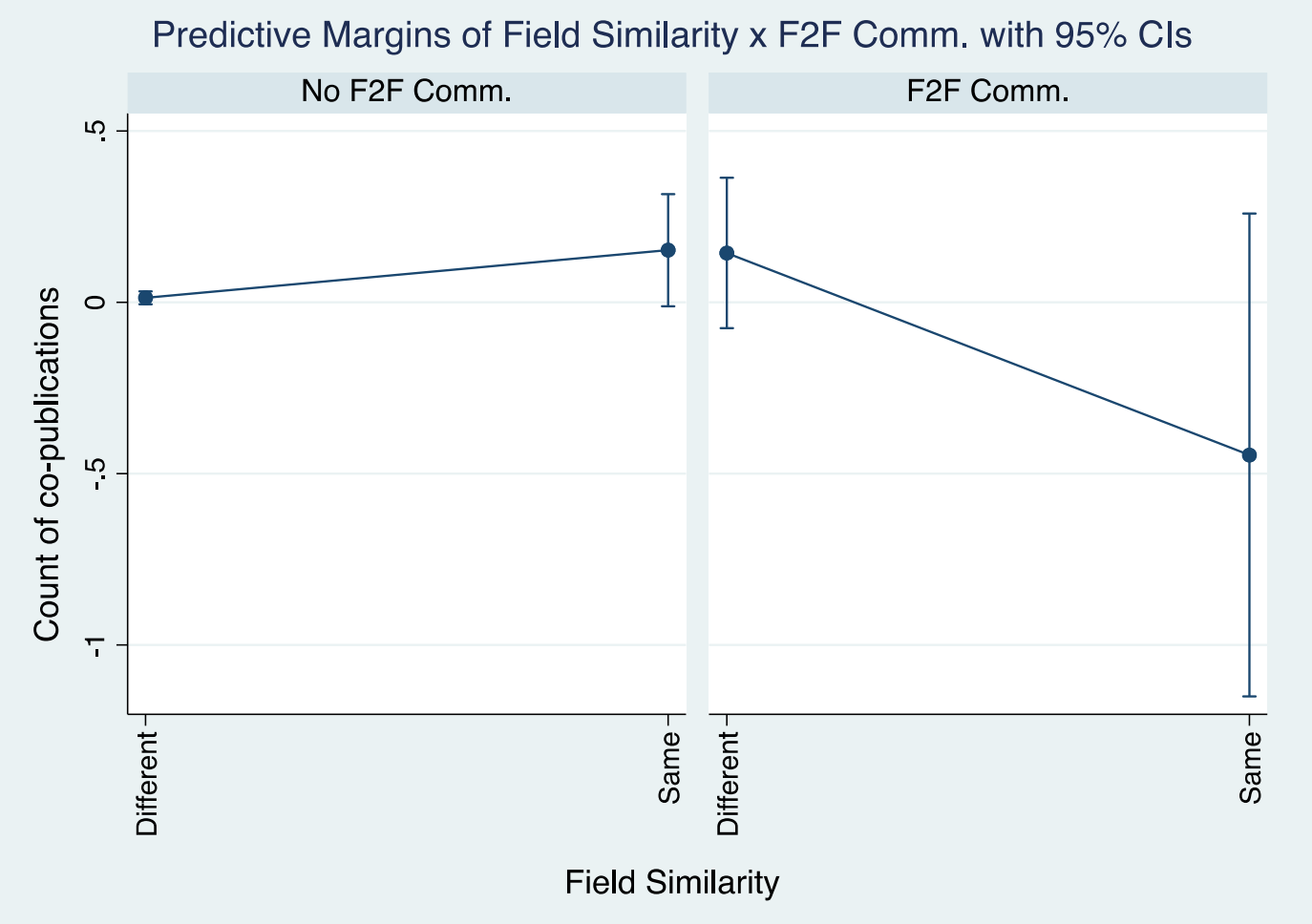


Figure 6. Margins Plot of Co-Publication Count and Grant Co-Applicant

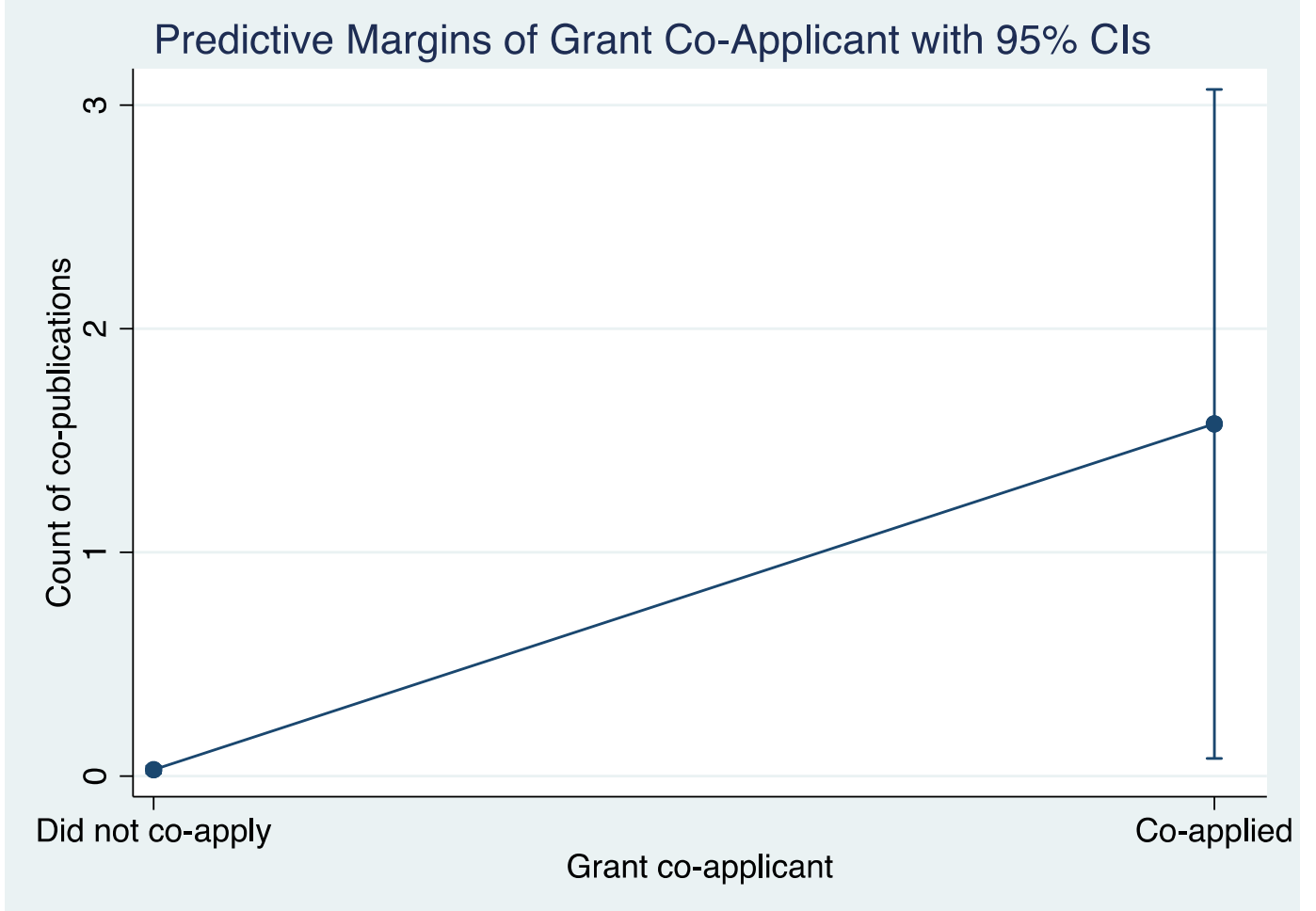

Figure 7. Margins Plot of Forward Citation Count and Field Similarity for Different vs. Same Room Dyads

Predictive Margins of Field Similarity x Same Room with 95\% Cls

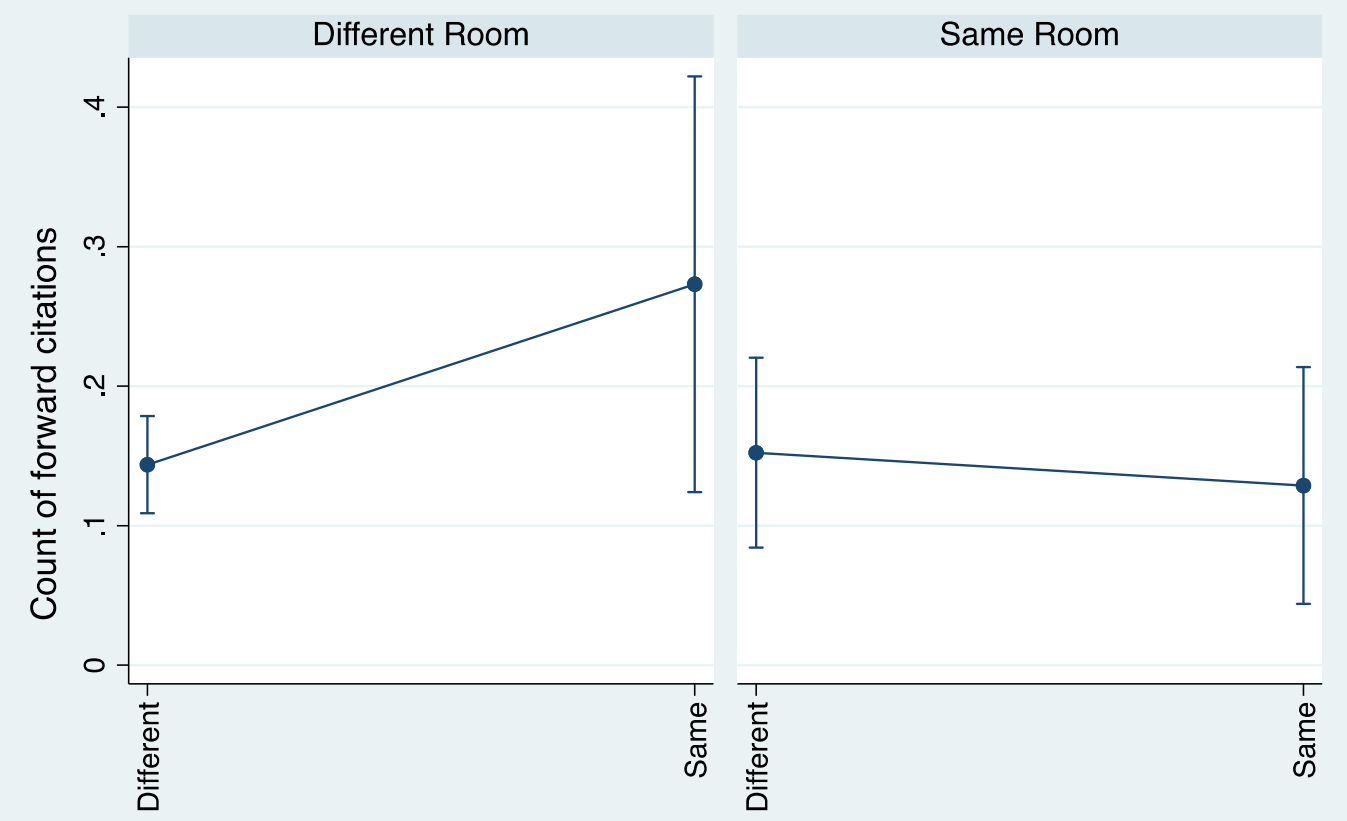

Field Similarity 
Figure 8. Margins Plot of Forward Citations and Field Similarity for Communicating vs. NonCommunicating Dyads

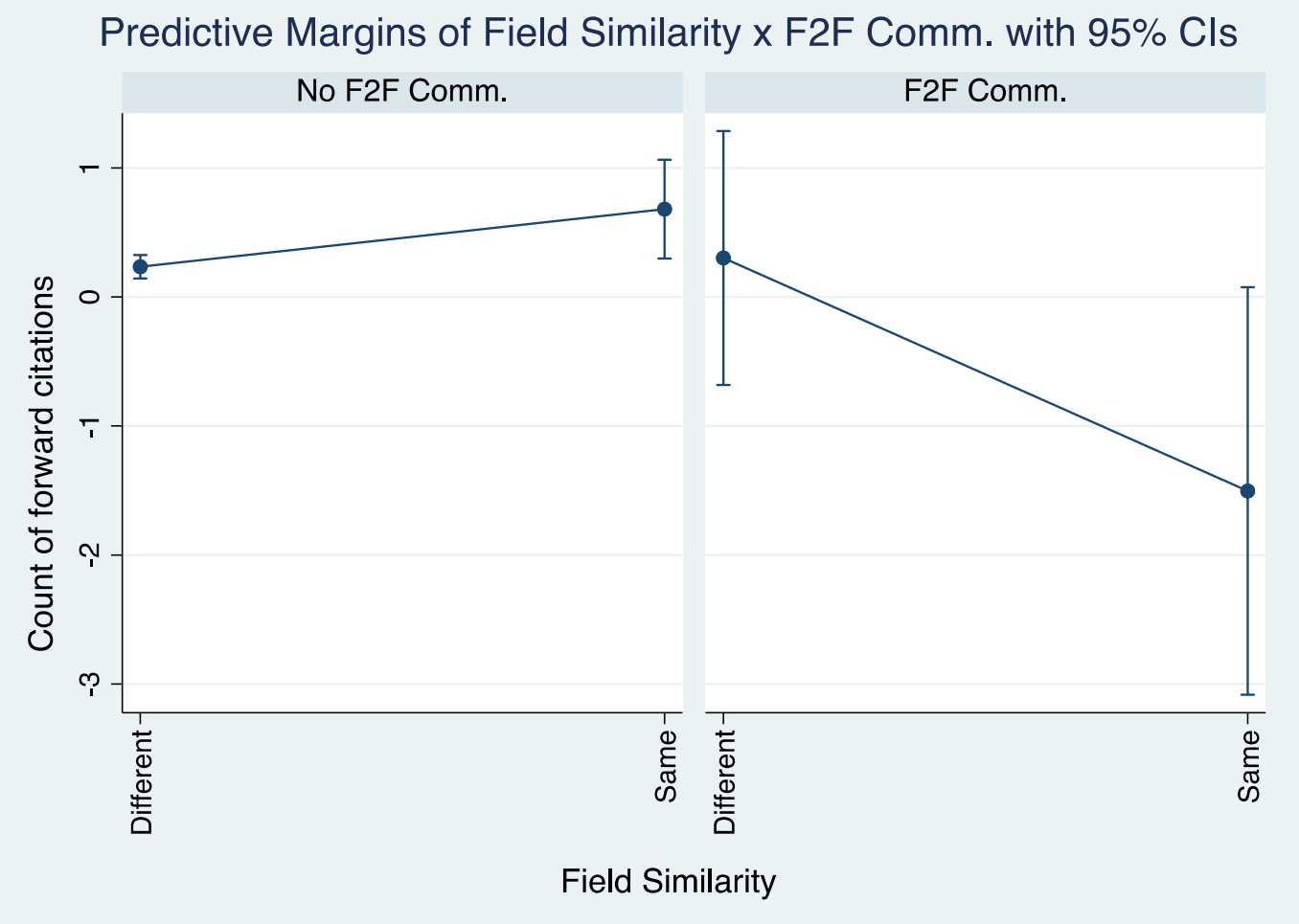




\section{APPENDIX}

Table A1. Relationships Between Knowledge Sharing and Transfer with All Control Variables

\begin{tabular}{|c|c|c|c|c|c|c|c|c|}
\hline \multicolumn{9}{|c|}{ Effects from Regression Analysis of Knowledge Transfer (15,817 Dyads) } \\
\hline Variable & $\begin{array}{l}\text { Model } 1 \\
\text { OLS }\end{array}$ & $\begin{array}{c}\text { Model } 2 \\
\text { 2sls }\end{array}$ & $\begin{array}{c}\text { Model } 3 \\
\text { OLS } \\
\end{array}$ & $\begin{array}{c}\text { Model } 4 \\
\text { 2sls } \\
\end{array}$ & $\begin{array}{c}\text { Model } 5 \\
\text { OLS }\end{array}$ & $\begin{array}{c}\text { Model } 6 \\
\text { 2sls } \\
\end{array}$ & $\begin{array}{c}\text { Model } 7 \\
\text { OLS }\end{array}$ & $\begin{array}{c}\text { Model } 8 \\
\text { 2sls } \\
\end{array}$ \\
\hline Same room & $\begin{array}{c}0.164^{*} \\
(0.0864)\end{array}$ & & $\begin{array}{l}0.0574 \\
(0.125)\end{array}$ & & $\begin{array}{l}0.0429 \\
(0.108)\end{array}$ & & $\begin{array}{l}-0.0596 \\
(0.136)\end{array}$ & \\
\hline F2F communication & & $\begin{array}{l}1.292 * \\
(0.675)\end{array}$ & & $\begin{array}{c}0.330 \\
(0.955)\end{array}$ & & $\begin{array}{c}0.285 \\
(0.795)\end{array}$ & & $\begin{array}{c}-0.802 \\
(1.072)\end{array}$ \\
\hline Same room x Same field specialty & & & $\begin{array}{l}-0.123 \\
(0.126)\end{array}$ & & & & $\begin{array}{l}-0.118 \\
(0.126)\end{array}$ & \\
\hline F2F comm. $x$ Same field specialty & & & & $\begin{array}{c}1.103 \\
(1.021)\end{array}$ & & & & $\begin{array}{l}1.248 \\
(1.055)\end{array}$ \\
\hline Same room x Low intellectual similarity & & & & & $\begin{array}{l}-0.0367 \\
(0.151)\end{array}$ & & $\begin{array}{l}-0.0379 \\
(0.151)\end{array}$ & \\
\hline Same room x Moderate intellectual similarity & & & & & $\begin{array}{c}0.387 * * * \\
(0.142)\end{array}$ & & $\begin{array}{c}0.386^{* * *} \\
(0.142)\end{array}$ & \\
\hline F2F comm. x Low intellectual similarity & & & & & & $\begin{array}{l}-0.287 \\
(1.216)\end{array}$ & & $\begin{array}{c}-0.309 \\
(1.269)\end{array}$ \\
\hline F2F comm. x Moderate intellectual similarity & & & & & & $\begin{array}{c}3.608^{* * *} \\
(1.278)\end{array}$ & & $\begin{array}{c}3.624 * * * \\
(1.343)\end{array}$ \\
\hline Same field specialty & $\begin{array}{l}-0.0178 \\
(0.114)\end{array}$ & $\begin{array}{l}-0.0526 \\
(0.112)\end{array}$ & $\begin{array}{l}0.0146 \\
(0.123)\end{array}$ & $\begin{array}{l}0.0610 \\
(0.162)\end{array}$ & $\begin{array}{l}-0.0191 \\
(0.114)\end{array}$ & $\begin{array}{l}-0.0543 \\
(0.113)\end{array}$ & $\begin{array}{l}0.0122 \\
(0.123)\end{array}$ & $\begin{array}{l}0.0741 \\
(0.169)\end{array}$ \\
\hline Low intellectual similarity (vs. High) & $\begin{array}{c}-1.581^{* * *} \\
(0.282)\end{array}$ & $\begin{array}{c}-1.567 * * * \\
(0.282)\end{array}$ & $\begin{array}{c}-1.581^{* * *} \\
(0.282)\end{array}$ & $\begin{array}{c}-1.574 * * * \\
(0.284)\end{array}$ & $\begin{array}{c}-1.573^{* * *} \\
(0.286)\end{array}$ & $\begin{array}{c}-1.569 * * * \\
(0.303)\end{array}$ & $\begin{array}{c}-1.572 * * * \\
(0.286)\end{array}$ & $\begin{array}{c}-1.576^{* * *} \\
(0.311)\end{array}$ \\
\hline Moderate intellectual similarity (vs. High) & $\begin{array}{c}0.454^{* * *} \\
(0.145)\end{array}$ & $\begin{array}{c}0.478^{* * *} \\
(0.147)\end{array}$ & $\begin{array}{c}0.454^{* * *} \\
(0.145)\end{array}$ & $\begin{array}{c}2.048 * * * \\
(0.212)\end{array}$ & $\begin{array}{c}0.351^{* *} \\
(0.146)\end{array}$ & $\begin{array}{c}1.781^{* * *} \\
(0.229)\end{array}$ & $\begin{array}{c}0.352^{* *} \\
(0.146)\end{array}$ & $\begin{array}{c}1.783^{* * *} \\
(0.234)\end{array}$ \\
\hline Post co-author & $\begin{array}{l}-0.0510 \\
(0.330)\end{array}$ & & $\begin{array}{l}-0.0532 \\
(0.330)\end{array}$ & & $\begin{array}{l}-0.0610 \\
(0.330)\end{array}$ & & $\begin{array}{l}-0.0632 \\
(0.330)\end{array}$ & \\
\hline Grant co-applicant & $\begin{array}{l}-0.107 \\
(0.619)\end{array}$ & & $\begin{array}{l}-0.0982 \\
(0.619)\end{array}$ & & $\begin{array}{l}-0.105 \\
(0.620)\end{array}$ & & $\begin{array}{l}-0.0971 \\
(0.620)\end{array}$ & \\
\hline Prior co-author & $\begin{array}{l}-1.248 \\
(0.867)\end{array}$ & $\begin{array}{l}-1.617^{*} \\
(0.896)\end{array}$ & $\begin{array}{l}-1.257 \\
(0.866)\end{array}$ & $\begin{array}{l}-1.588^{*} \\
(0.933)\end{array}$ & $\begin{array}{l}-1.250 \\
(0.868)\end{array}$ & $\begin{array}{l}-1.567^{*} \\
(0.933)\end{array}$ & $\begin{array}{l}-1.259 \\
(0.866)\end{array}$ & $\begin{array}{l}-1.536 \\
(0.995)\end{array}$ \\
\hline Geographic distance & $\begin{array}{l}0.00794 \\
(0.0127)\end{array}$ & $\begin{array}{l}0.00742 \\
(0.0127)\end{array}$ & $\begin{array}{l}0.00795 \\
(0.0127)\end{array}$ & $\begin{array}{l}0.00763 \\
(0.0126)\end{array}$ & $\begin{array}{l}0.00783 \\
(0.0127)\end{array}$ & $\begin{array}{l}0.00859 \\
(0.0123)\end{array}$ & $\begin{array}{l}0.00784 \\
(0.0127)\end{array}$ & $\begin{array}{l}0.00883 \\
(0.0123)\end{array}$ \\
\hline Same institution & $\begin{array}{l}0.0667 \\
(0.117)\end{array}$ & $\begin{array}{l}0.0289 \\
(0.116)\end{array}$ & $\begin{array}{l}0.0661 \\
(0.117)\end{array}$ & $\begin{array}{l}0.0318 \\
(0.116)\end{array}$ & $\begin{array}{l}0.0644 \\
(0.117)\end{array}$ & $\begin{array}{l}0.0329 \\
(0.116)\end{array}$ & $\begin{array}{l}0.0638 \\
(0.117)\end{array}$ & $\begin{array}{l}0.0362 \\
(0.120)\end{array}$ \\
\hline Same department & $\begin{array}{l}0.0540 \\
(0.154)\end{array}$ & $\begin{array}{l}-0.0405 \\
(0.161)\end{array}$ & $\begin{array}{l}0.0537 \\
(0.154)\end{array}$ & $\begin{array}{l}-0.0282 \\
(0.159)\end{array}$ & $\begin{array}{l}0.0524 \\
(0.154)\end{array}$ & $\begin{array}{c}-0.0293 \\
(0.161)\end{array}$ & $\begin{array}{l}0.0521 \\
(0.154)\end{array}$ & $\begin{array}{l}-0.0155 \\
(0.165)\end{array}$ \\
\hline Same imaging modality & $\begin{array}{l}-0.151^{*} \\
(0.0863)\end{array}$ & $\begin{array}{c}-0.180^{* *} \\
(0.0889)\end{array}$ & $\begin{array}{c}-0.152^{*} \\
(0.0864)\end{array}$ & $\begin{array}{c}-0.177^{* *} \\
(0.0879)\end{array}$ & $\begin{array}{c}-0.150^{*} \\
(0.0864)\end{array}$ & $\begin{array}{c}-0.179 * * \\
(0.0900)\end{array}$ & $\begin{array}{l}-0.150^{*} \\
(0.0865)\end{array}$ & $\begin{array}{c}-0.176^{*} \\
(0.0915)\end{array}$ \\
\hline Both clinicians & $\begin{array}{c}-0.544 * * * \\
(0.102)\end{array}$ & $\begin{array}{c}-0.554^{* * *} \\
(0.101)\end{array}$ & $\begin{array}{c}-0.544 * * * \\
(0.102)\end{array}$ & $\begin{array}{c}-0.554 * * * \\
(0.101)\end{array}$ & $\begin{array}{c}-0.546 * * * \\
(0.102)\end{array}$ & $\begin{array}{c}-0.557 * * * \\
(0.102)\end{array}$ & $\begin{array}{c}-0.546 * * * \\
(0.102)\end{array}$ & $\begin{array}{c}-0.557^{* * *} \\
(0.105)\end{array}$ \\
\hline Both imagers & $\begin{array}{c}0.235 \\
(0.143)\end{array}$ & $\begin{array}{l}0.248^{*} \\
(0.142)\end{array}$ & $\begin{array}{c}0.235 \\
(0.143)\end{array}$ & $\begin{array}{l}0.243^{*} \\
(0.142)\end{array}$ & $\begin{array}{c}0.235 \\
(0.143)\end{array}$ & $\begin{array}{l}0.257^{*} \\
(0.140)\end{array}$ & $\begin{array}{c}0.234 \\
(0.143)\end{array}$ & $\begin{array}{l}0.251^{*} \\
(0.147)\end{array}$ \\
\hline Same rank & $\begin{array}{c}-0.166^{*} \\
(0.0934)\end{array}$ & $\begin{array}{l}-0.171^{*} \\
(0.0925)\end{array}$ & $\begin{array}{l}-0.167 * \\
(0.0935)\end{array}$ & $\begin{array}{l}-0.170 * \\
(0.0924)\end{array}$ & $\begin{array}{l}-0.167 * \\
(0.0934)\end{array}$ & $\begin{array}{l}-0.183 * \\
(0.0936)\end{array}$ & $\begin{array}{l}-0.168^{*} \\
(0.0935)\end{array}$ & $\begin{array}{l}-0.182 * \\
(0.0950)\end{array}$ \\
\hline Both females & $\begin{array}{l}-0.117 \\
(0.125)\end{array}$ & $\begin{array}{l}-0.154 \\
(0.129)\end{array}$ & $\begin{array}{l}-0.116 \\
(0.125)\end{array}$ & $\begin{array}{l}-0.157 \\
(0.128)\end{array}$ & $\begin{array}{l}-0.118 \\
(0.125)\end{array}$ & $\begin{array}{l}-0.155 \\
(0.128)\end{array}$ & $\begin{array}{l}-0.117 \\
(0.125)\end{array}$ & $\begin{array}{l}-0.159 \\
(0.130)\end{array}$ \\
\hline Both males & $\begin{array}{l}0.0157 \\
(0.113)\end{array}$ & $\begin{array}{l}0.00387 \\
(0.112)\end{array}$ & $\begin{array}{l}0.0164 \\
(0.113)\end{array}$ & $\begin{array}{c}0.00463 \\
(0.112)\end{array}$ & $\begin{array}{l}0.0142 \\
(0.113)\end{array}$ & $\begin{array}{l}0.0104 \\
(0.112)\end{array}$ & $\begin{array}{l}0.0148 \\
(0.113)\end{array}$ & $\begin{array}{l}0.0113 \\
(0.117)\end{array}$ \\
\hline
\end{tabular}




\begin{tabular}{|c|c|c|c|c|c|c|c|c|}
\hline Super expert & $\begin{array}{c}-0.114 \\
(0.342)\end{array}$ & $\begin{array}{c}-0.0891 \\
(0.333)\end{array}$ & $\begin{array}{l}-0.114 \\
(0.342)\end{array}$ & $\begin{array}{c}-0.0993 \\
(0.332)\end{array}$ & $\begin{array}{c}-0.115 \\
(0.341)\end{array}$ & $\begin{array}{c}-0.0915 \\
(0.336)\end{array}$ & $\begin{array}{c}-0.114 \\
(0.341)\end{array}$ & $\begin{array}{c}-0.103 \\
(0.354)\end{array}$ \\
\hline Rank difference & $\begin{array}{c}-0.000514 \\
(0.0487)\end{array}$ & $\begin{array}{l}0.00149 \\
(0.0482)\end{array}$ & $\begin{array}{c}-0.000652 \\
(0.0487)\end{array}$ & $\begin{array}{l}0.00222 \\
(0.0482)\end{array}$ & $\begin{array}{c}0.000266 \\
(0.0486)\end{array}$ & $\begin{array}{l}-0.00247 \\
(0.0484)\end{array}$ & $\begin{array}{c}0.000135 \\
(0.0487)\end{array}$ & $\begin{array}{l}-0.00168 \\
(0.0503)\end{array}$ \\
\hline Prior citations & $\begin{array}{c}-0.408 * * \\
(0.181)\end{array}$ & $\begin{array}{c}-0.440 * * \\
(0.187)\end{array}$ & $\begin{array}{c}-0.408^{* *} \\
(0.181)\end{array}$ & $\begin{array}{c}-0.441^{* *} \\
(0.187)\end{array}$ & $\begin{array}{c}-0.401^{* *} \\
(0.180)\end{array}$ & $\begin{array}{c}-0.410^{* *} \\
(0.180)\end{array}$ & $\begin{array}{c}-0.401^{* *} \\
(0.180)\end{array}$ & $\begin{array}{c}-0.411 * * \\
(0.188)\end{array}$ \\
\hline Prior MeSH keywords & $\begin{array}{c}0.00412 * * * \\
(0.000437)\end{array}$ & $\begin{array}{c}0.00414 * * * \\
(0.000436)\end{array}$ & $\begin{array}{c}0.00412 * * * \\
(0.000437)\end{array}$ & $\begin{array}{c}0.00413^{* * *} \\
(0.000436)\end{array}$ & $\begin{array}{c}0.00412 * * * \\
(0.000436)\end{array}$ & $\begin{array}{c}0.00411^{* * *} \\
(0.000434)\end{array}$ & $\begin{array}{c}0.00412 * * * \\
(0.000436)\end{array}$ & $\begin{array}{c}0.00410 * * * \\
(0.000442)\end{array}$ \\
\hline Constant & $\begin{array}{c}2.797 * * * \\
(0.458)\end{array}$ & $\begin{array}{c}2.738 * * * \\
(0.463)\end{array}$ & $\begin{array}{c}2.793 * * * \\
(0.458)\end{array}$ & $\begin{array}{c}1.152 * * * \\
(0.386)\end{array}$ & $\begin{array}{c}2.826 * * * \\
(0.457)\end{array}$ & $\begin{array}{c}1.263^{* * *} \\
(0.389)\end{array}$ & $\begin{array}{c}2.822 * * * \\
(0.457)\end{array}$ & $\begin{array}{c}1.243^{* * *} \\
(0.400)\end{array}$ \\
\hline Night FE & $\mathrm{Y}$ & $\mathrm{Y}$ & $\mathrm{Y}$ & $\mathrm{Y}$ & $\mathrm{Y}$ & $\mathrm{Y}$ & $\mathrm{Y}$ & $\mathrm{Y}$ \\
\hline Room FE & $\mathrm{Y}$ & $\mathrm{Y}$ & $\mathrm{Y}$ & $\mathrm{Y}$ & $\mathrm{Y}$ & $\mathrm{Y}$ & $\mathrm{Y}$ & $\mathrm{Y}$ \\
\hline Observations & 15,817 & 15,817 & 15,817 & 15,817 & 15,817 & 15,817 & 15,817 & 15,817 \\
\hline R-squared & 0.326 & 0.318 & 0.326 & 0.317 & 0.327 & 0.303 & 0.327 & 0.322 \\
\hline
\end{tabular}

Two-way robust standard errors in parentheses

*** $\mathrm{p}<0.01,{ }^{* *} \mathrm{p}<0.05,{ }^{*} \mathrm{p}<0.1$ 
Table A2. Relationships Between Knowledge Sharing and Creation with All Control Variables

\begin{tabular}{|c|c|c|c|c|c|c|c|c|c|}
\hline \multicolumn{10}{|c|}{ Effects from Regression Analysis of Knowledge Creation (15,817 Dyads) } \\
\hline Variable & $\begin{array}{c}\text { Model } 1 \\
\text { OLS }\end{array}$ & $\begin{array}{c}\text { Model } 2 \\
\text { 2sls }\end{array}$ & $\begin{array}{c}\text { Model } 3 \\
\text { OLS }\end{array}$ & $\begin{array}{c}\text { Model } 4 \\
\text { 2sls }\end{array}$ & $\begin{array}{c}\text { Model } 5 \\
\text { OLS }\end{array}$ & $\begin{array}{c}\text { Model } 6 \\
\text { 2sls }\end{array}$ & $\begin{array}{c}\text { Model } 7 \\
\text { OLS }\end{array}$ & $\begin{array}{c}\text { Model } 8 \\
\text { 2sls }\end{array}$ & $\begin{array}{l}\text { Model } 9 \\
\text { OLS }\end{array}$ \\
\hline Same room & $\begin{array}{l}0.00345 \\
(0.0145)\end{array}$ & & $\begin{array}{l}-0.0851 \\
(0.0538)\end{array}$ & & $\begin{array}{l}-0.0111 \\
(0.0320)\end{array}$ & & $\begin{array}{l}-0.0985 \\
(0.0670)\end{array}$ & & $\begin{array}{l}-0.0985 \\
(0.0670)\end{array}$ \\
\hline F2F communication & & $\begin{array}{l}0.0376 \\
(0.111)\end{array}$ & & $\begin{array}{c}-0.598 \\
(0.440)\end{array}$ & & $\begin{array}{c}-0.0589 \\
(0.236)\end{array}$ & & $\begin{array}{c}-0.699 \\
(0.538)\end{array}$ & \\
\hline Same room x Same field specialty & & & $\begin{array}{l}-0.101 * \\
(0.0571)\end{array}$ & & & & $\begin{array}{c}-0.101 * \\
(0.0567)\end{array}$ & & $\begin{array}{c}-0.101^{*} \\
(0.0567)\end{array}$ \\
\hline F2F comm. x Same field specialty & & & & $\begin{array}{c}-0.729 \\
(0.468)\end{array}$ & & & & $\begin{array}{l}-0.735 \\
(0.470)\end{array}$ & $\begin{array}{c}0.0144 \\
(0.0302)\end{array}$ \\
\hline Same room x Low intellectual similarity & & & & & $\begin{array}{c}0.0155 \\
(0.0305)\end{array}$ & & $\begin{array}{c}0.0145 \\
(0.0302)\end{array}$ & & $\begin{array}{c}0.0286 \\
(0.0315)\end{array}$ \\
\hline Same room x Mod. intellectual similarity & & & & & $\begin{array}{c}0.0297 \\
(0.0317)\end{array}$ & & $\begin{array}{c}0.0286 \\
(0.0315)\end{array}$ & & \\
\hline F2F comm. x Low intellectual similarity & & & & & & $\begin{array}{l}0.0852 \\
(0.238)\end{array}$ & & $\begin{array}{l}0.0722 \\
(0.239)\end{array}$ & \\
\hline F2F comm. x Mod. intellectual similarity & & & & & & $\begin{array}{c}0.241 \\
(0.249)\end{array}$ & & $\begin{array}{c}0.251 \\
(0.256)\end{array}$ & \\
\hline Same field specialty & $\begin{array}{c}0.0599 \\
(0.0380)\end{array}$ & $\begin{array}{l}0.0640 * \\
(0.0386)\end{array}$ & $\begin{array}{l}0.0868 * \\
(0.0517)\end{array}$ & $\begin{array}{c}0.139 * \\
(0.0836)\end{array}$ & $\begin{array}{c}0.0598 \\
(0.0380)\end{array}$ & $\begin{array}{c}0.0643 \\
(0.0393)\end{array}$ & $\begin{array}{l}0.0866 * \\
(0.0516)\end{array}$ & $\begin{array}{c}0.140^{*} \\
(0.0842)\end{array}$ & $\begin{array}{l}0.0865 * \\
(0.0515)\end{array}$ \\
\hline Low intellectual similarity (vs. High) & $\begin{array}{c}-0.0641^{* *} \\
(0.0323)\end{array}$ & $\begin{array}{c}-0.0636^{* *} \\
(0.0324)\end{array}$ & $\begin{array}{c}-0.0639 * * \\
(0.0322)\end{array}$ & $\begin{array}{c}-0.0686^{* *} \\
(0.0344)\end{array}$ & $\begin{array}{c}-0.0682 * \\
(0.0367)\end{array}$ & $\begin{array}{l}-0.0723 \\
(0.0476)\end{array}$ & $\begin{array}{c}-0.0677^{*} \\
(0.0365)\end{array}$ & $\begin{array}{l}-0.0783 \\
(0.0507)\end{array}$ & $\begin{array}{l}-0.0678 * \\
(0.0367)\end{array}$ \\
\hline Mod. intellectual similarity (vs. High) & $\begin{array}{c}-0.0437^{* *} \\
(0.0194)\end{array}$ & $\begin{array}{c}-0.0444 * * \\
(0.0191)\end{array}$ & $\begin{array}{c}-0.0434^{* *} \\
(0.0193)\end{array}$ & $\begin{array}{c}0.0214 \\
(0.0169)\end{array}$ & $\begin{array}{c}-0.0514 * * \\
(0.0237)\end{array}$ & $\begin{array}{c}0.00940 \\
(0.0181)\end{array}$ & $\begin{array}{c}-0.0509^{* *} \\
(0.0235)\end{array}$ & $\begin{array}{c}0.0101 \\
(0.0188)\end{array}$ & $\begin{array}{c}-0.0508 * * \\
(0.0235)\end{array}$ \\
\hline Grant co-applicant & $\begin{array}{c}1.539 * * \\
(0.765)\end{array}$ & & $\begin{array}{c}1.546 * * \\
(0.764)\end{array}$ & & $\begin{array}{c}1.540 * * \\
(0.765)\end{array}$ & & $\begin{array}{c}1.546 * * \\
(0.763)\end{array}$ & & $\begin{array}{c}1.546^{* *} \\
(0.763)\end{array}$ \\
\hline Grant awardee & & & & & & & & & $\begin{array}{r}-0.00192 \\
(0.0128)\end{array}$ \\
\hline Prior co-author & $\begin{array}{l}6.018^{*} \\
(3.496)\end{array}$ & $\begin{array}{l}6.162 * \\
(3.459)\end{array}$ & $\begin{array}{c}6.010 * \\
(3.493)\end{array}$ & $\begin{array}{l}6.181 * \\
(3.484)\end{array}$ & $\begin{array}{c}6.017^{*} \\
(3.495)\end{array}$ & $\begin{array}{l}6.174 * \\
(3.476)\end{array}$ & $\begin{array}{c}6.008^{*} \\
(3.493)\end{array}$ & $\begin{array}{l}6.192 * \\
(3.501)\end{array}$ & $\begin{array}{l}6.008^{*} \\
(3.493)\end{array}$ \\
\hline Geographic distance & $\begin{array}{l}-0.000645 \\
(0.000751)\end{array}$ & $\begin{array}{l}-0.000827 \\
(0.000800)\end{array}$ & $\begin{array}{c}-0.000634 \\
(0.000745)\end{array}$ & $\begin{array}{l}-0.000689 \\
(0.000834)\end{array}$ & $\begin{array}{l}-0.000640 \\
(0.000754)\end{array}$ & $\begin{array}{l}-0.000729 \\
(0.000840)\end{array}$ & $\begin{array}{l}-0.000630 \\
(0.000752)\end{array}$ & $\begin{array}{c}-0.000589 \\
(0.000895)\end{array}$ & $\begin{array}{l}-0.000631 \\
(0.000754)\end{array}$ \\
\hline Same institution & $\begin{array}{c}0.0584^{* *} \\
(0.0244)\end{array}$ & $\begin{array}{c}0.0629 * * \\
(0.0255)\end{array}$ & $\begin{array}{c}0.0578 * * \\
(0.0243)\end{array}$ & $\begin{array}{c}0.0648 * * \\
(0.0261)\end{array}$ & $\begin{array}{c}0.0583 * * \\
(0.0245)\end{array}$ & $\begin{array}{c}0.0633 * * \\
(0.0259)\end{array}$ & $\begin{array}{l}0.0578 * * \\
(0.0243)\end{array}$ & $\begin{array}{l}0.0652 * * \\
(0.0265)\end{array}$ & $\begin{array}{c}0.0578 * * \\
(0.0243)\end{array}$ \\
\hline Same department & $\begin{array}{l}0.0776 * \\
(0.0452)\end{array}$ & $\begin{array}{l}0.0807^{*} \\
(0.0478)\end{array}$ & $\begin{array}{l}0.0774 * \\
(0.0451)\end{array}$ & $\begin{array}{l}0.0888 * \\
(0.0526)\end{array}$ & $\begin{array}{l}0.0775 * \\
(0.0451)\end{array}$ & $\begin{array}{l}0.0820 * \\
(0.0496)\end{array}$ & $\begin{array}{l}0.0772 * \\
(0.0451)\end{array}$ & $\begin{array}{l}0.0901 * \\
(0.0543)\end{array}$ & $\begin{array}{l}0.0772 * \\
(0.0450)\end{array}$ \\
\hline Same imaging modality & $\begin{array}{c}0.0453 \\
(0.0316)\end{array}$ & $\begin{array}{c}0.0458 \\
(0.0323)\end{array}$ & $\begin{array}{c}0.0450 \\
(0.0316)\end{array}$ & $\begin{array}{c}0.0475 \\
(0.0329)\end{array}$ & $\begin{array}{c}0.0452 \\
(0.0315)\end{array}$ & $\begin{array}{c}0.0461 \\
(0.0327)\end{array}$ & $\begin{array}{c}0.0450 \\
(0.0315)\end{array}$ & $\begin{array}{c}0.0478 \\
(0.0333)\end{array}$ & $\begin{array}{c}0.0450 \\
(0.0315)\end{array}$ \\
\hline Both clinicians & $\begin{array}{c}0.0330 * \\
(0.0177)\end{array}$ & $\begin{array}{l}0.0312 * \\
(0.0180)\end{array}$ & $\begin{array}{c}0.0329 * \\
(0.0177)\end{array}$ & $\begin{array}{c}0.0314 * \\
(0.0185)\end{array}$ & $\begin{array}{c}0.0327 * \\
(0.0176)\end{array}$ & $\begin{array}{l}0.0308 * \\
(0.0178)\end{array}$ & $\begin{array}{c}0.0327 * \\
(0.0176)\end{array}$ & $\begin{array}{l}0.0311 * \\
(0.0182)\end{array}$ & $\begin{array}{c}0.0327 * \\
(0.0175)\end{array}$ \\
\hline Both imagers & $\begin{array}{c}0.0150 \\
(0.0311)\end{array}$ & $\begin{array}{c}0.0153 \\
(0.0316)\end{array}$ & $\begin{array}{c}0.0147 \\
(0.0312)\end{array}$ & $\begin{array}{c}0.0117 \\
(0.0327)\end{array}$ & $\begin{array}{c}0.0149 \\
(0.0312)\end{array}$ & $\begin{array}{c}0.0156 \\
(0.0318)\end{array}$ & $\begin{array}{c}0.0146 \\
(0.0312)\end{array}$ & $\begin{array}{c}0.0120 \\
(0.0330)\end{array}$ & $\begin{array}{c}0.0147 \\
(0.0314)\end{array}$ \\
\hline Same rank & $\begin{array}{c}-0.0262 \\
(0.0225)\end{array}$ & $\begin{array}{l}-0.0275 \\
(0.0219)\end{array}$ & $\begin{array}{l}-0.0269 \\
(0.0227)\end{array}$ & $\begin{array}{l}-0.0266 \\
(0.0216)\end{array}$ & $\begin{array}{l}-0.0263 \\
(0.0225)\end{array}$ & $\begin{array}{c}-0.0280 \\
(0.0219)\end{array}$ & $\begin{array}{l}-0.0270 \\
(0.0228)\end{array}$ & $\begin{array}{l}-0.0271 \\
(0.0217)\end{array}$ & $\begin{array}{l}-0.0270 \\
(0.0228)\end{array}$ \\
\hline Both females & $\begin{array}{l}0.00441 \\
(0.0232)\end{array}$ & $\begin{array}{c}0.00433 \\
(0.0229)\end{array}$ & $\begin{array}{l}0.00510 \\
(0.0230)\end{array}$ & $\begin{array}{l}0.00244 \\
(0.0238)\end{array}$ & $\begin{array}{l}0.00430 \\
(0.0232)\end{array}$ & $\begin{array}{l}0.00480 \\
(0.0232)\end{array}$ & $\begin{array}{l}0.00499 \\
(0.0230)\end{array}$ & $\begin{array}{l}0.00284 \\
(0.0240)\end{array}$ & $\begin{array}{c}0.00493 \\
(0.0230)\end{array}$ \\
\hline Both males & $\begin{array}{c}0.0143 \\
(0.0155)\end{array}$ & $\begin{array}{c}0.0137 \\
(0.0161)\end{array}$ & $\begin{array}{c}0.0149 \\
(0.0157)\end{array}$ & $\begin{array}{c}0.0142 \\
(0.0164)\end{array}$ & $\begin{array}{c}0.0142 \\
(0.0155)\end{array}$ & $\begin{array}{c}0.0138 \\
(0.0158)\end{array}$ & $\begin{array}{c}0.0148 \\
(0.0157)\end{array}$ & $\begin{array}{c}0.0144 \\
(0.0162)\end{array}$ & $\begin{array}{c}0.0148 \\
(0.0158)\end{array}$ \\
\hline Super expert & $\begin{array}{c}0.0629 \\
(0.0462)\end{array}$ & $\begin{array}{c}0.0672 \\
(0.0465)\end{array}$ & $\begin{array}{c}0.0631 \\
(0.0463)\end{array}$ & $\begin{array}{c}0.0605 \\
(0.0460)\end{array}$ & $\begin{array}{c}0.0629 \\
(0.0463)\end{array}$ & $\begin{array}{c}0.0664 \\
(0.0466)\end{array}$ & $\begin{array}{c}0.0632 \\
(0.0464)\end{array}$ & $\begin{array}{c}0.0597 \\
(0.0466)\end{array}$ & $\begin{array}{c}0.0631 \\
(0.0461)\end{array}$ \\
\hline Rank difference & -0.00310 & -0.00326 & -0.00321 & -0.00278 & -0.00310 & -0.00340 & -0.00321 & -0.00294 & -0.00322 \\
\hline
\end{tabular}




\begin{tabular}{|c|c|c|c|c|c|c|c|c|c|}
\hline & $(0.00308)$ & $(0.00309)$ & $(0.00314)$ & $(0.00297)$ & $(0.00310)$ & $(0.00305)$ & $(0.00314)$ & $(0.00296)$ & $(0.00314)$ \\
\hline Prior citations & $\begin{array}{c}0.239 * \\
(0.141)\end{array}$ & $\begin{array}{c}0.239 * \\
(0.141)\end{array}$ & $\begin{array}{l}0.239 * \\
(0.141)\end{array}$ & $\begin{array}{c}0.238^{*} \\
(0.141)\end{array}$ & $\begin{array}{c}0.239 * \\
(0.141)\end{array}$ & $\begin{array}{c}0.242 * \\
(0.143)\end{array}$ & $\begin{array}{c}0.240 * \\
(0.141)\end{array}$ & $\begin{array}{c}0.241^{*} \\
(0.143)\end{array}$ & $\begin{array}{l}0.240^{*} \\
(0.141)\end{array}$ \\
\hline Prior MeSH keywords & $\begin{array}{c}-7.62 e-05 \\
(5.37 e-05)\end{array}$ & $\begin{array}{c}-7.42 \mathrm{e}-05 \\
(5.41 \mathrm{e}-05)\end{array}$ & $\begin{array}{l}-7.61 \mathrm{e}-05 \\
(5.39 \mathrm{e}-05)\end{array}$ & $\begin{array}{c}-7.88 \mathrm{e}-05 \\
(5.62 \mathrm{e}-05)\end{array}$ & $\begin{array}{c}-7.62 \mathrm{e}-05 \\
(5.36 \mathrm{e}-05)\end{array}$ & $\begin{array}{c}-7.65 e-05 \\
(5.59 e-05)\end{array}$ & $\begin{array}{c}-7.61 \mathrm{e}-05 \\
(5.35 \mathrm{e}-05)\end{array}$ & $\begin{array}{c}-8.12 \mathrm{e}-05 \\
(5.81 \mathrm{e}-05)\end{array}$ & $\begin{array}{c}-7.62 \mathrm{e}-05 \\
(5.37 \mathrm{e}-05)\end{array}$ \\
\hline Constant & $\begin{array}{c}0.0579 \\
(0.0415)\end{array}$ & $\begin{array}{c}0.0577 \\
(0.0424)\end{array}$ & $\begin{array}{c}0.0548 \\
(0.0400)\end{array}$ & $\begin{array}{l}-0.0186 \\
(0.0231)\end{array}$ & $\begin{array}{c}0.0615 \\
(0.0439)\end{array}$ & $\begin{array}{r}-0.00535 \\
(0.0229)\end{array}$ & $\begin{array}{c}0.0582 \\
(0.0424)\end{array}$ & $\begin{array}{l}-0.0244 \\
(0.0235)\end{array}$ & $\begin{array}{c}0.0582 \\
(0.0424)\end{array}$ \\
\hline Night FE & $\mathrm{Y}$ & $\mathrm{Y}$ & $\mathrm{Y}$ & $\mathrm{Y}$ & $\mathrm{Y}$ & $\mathrm{Y}$ & $\mathrm{Y}$ & $\mathrm{Y}$ & $\mathrm{Y}$ \\
\hline Observations & 15,817 & 15,817 & 15,817 & 15,817 & 15,817 & 15,817 & 15,817 & 15,817 & 15,817 \\
\hline R-squared & 0.082 & 0.078 & 0.083 & 0.064 & 0.082 & 0.076 & 0.083 & 0.062 & 0.083 \\
\hline
\end{tabular}

Two-way robust standard errors in parentheses

$* * * \mathrm{p}<0.01, * * \mathrm{p}<0.05, * \mathrm{p}<0.1$ 
Table A3. Relationships Between Knowledge Sharing and Diffusion with All Control Variables

\begin{tabular}{|c|c|c|c|c|c|c|c|c|}
\hline \multicolumn{9}{|c|}{ Effects from Regression Analysis of Knowledge Diffusion (15,817 Dyads) } \\
\hline Variable & $\begin{array}{c}\text { Model } 1 \\
\text { OLS }\end{array}$ & $\begin{array}{c}\text { Model } 2 \\
\text { 2sls }\end{array}$ & $\begin{array}{c}\text { Model } 3 \\
\text { OLS }\end{array}$ & $\begin{array}{c}\text { Model } 4 \\
\text { 2sls }\end{array}$ & $\begin{array}{c}\text { Model } 5 \\
\text { OLS }\end{array}$ & $\begin{array}{c}\text { Model } 6 \\
\text { 2sls }\end{array}$ & $\begin{array}{c}\text { Model } 7 \\
\text { OLS }\end{array}$ & $\begin{array}{c}\text { Model } 8 \\
\text { 2sls }\end{array}$ \\
\hline Same room & $\begin{array}{c}-0.0287 \\
(0.0633)\end{array}$ & & $\begin{array}{c}-0.254^{* *} \\
(0.121)\end{array}$ & & $\begin{array}{c}0.0111 \\
(0.133)\end{array}$ & & $\begin{array}{c}-0.214 \\
(0.165)\end{array}$ & \\
\hline F2F communication & & $\begin{array}{l}-0.219 \\
(0.507)\end{array}$ & & $\begin{array}{c}-2.185^{* *} \\
(0.985)\end{array}$ & & $\begin{array}{l}-0.0181 \\
(1.014)\end{array}$ & & $\begin{array}{l}-2.008 \\
(1.288)\end{array}$ \\
\hline Same room x Same field specialty & & & $\begin{array}{c}-0.259 * * \\
(0.120)\end{array}$ & & & & $\begin{array}{c}-0.260^{* *} \\
(0.120)\end{array}$ & \\
\hline F2F comm. x Same field specialty & & & & $\begin{array}{c}-2.253^{* *} \\
(1.017)\end{array}$ & & & & $\begin{array}{c}-2.284 * * \\
(1.040)\end{array}$ \\
\hline Same room $\mathrm{x}$ Low intellectual similarity & & & & & $\begin{array}{c}-0.103 \\
(0.128)\end{array}$ & & $\begin{array}{l}-0.106 \\
(0.128)\end{array}$ & \\
\hline Same room x Moderate intellectual similarity & & & & & $\begin{array}{r}-0.0310 \\
(0.131)\end{array}$ & & $\begin{array}{r}-0.0338 \\
(0.131)\end{array}$ & \\
\hline F2F comm. x Low intellectual similarity & & & & & & $\begin{array}{c}-0.716 \\
(1.029)\end{array}$ & & $\begin{array}{c}-0.757 \\
(1.038)\end{array}$ \\
\hline F2F comm. x Moderate intellectual similarity & & & & & & $\begin{array}{c}-0.00237 \\
(1.032)\end{array}$ & & $\begin{array}{l}0.0275 \\
(1.038)\end{array}$ \\
\hline Same field specialty & $\begin{array}{c}0.181^{*} \\
(0.0956)\end{array}$ & $\begin{array}{c}0.214^{* *} \\
(0.101)\end{array}$ & $\begin{array}{c}0.250 * * \\
(0.119)\end{array}$ & $\begin{array}{c}0.446 * * \\
(0.188)\end{array}$ & $\begin{array}{c}0.181^{*} \\
(0.0955)\end{array}$ & $\begin{array}{c}0.212 * * \\
(0.103)\end{array}$ & $\begin{array}{c}0.250 * * \\
(0.118)\end{array}$ & $\begin{array}{c}0.447 * * \\
(0.190)\end{array}$ \\
\hline Low intellectual similarity (vs. High) & $\begin{array}{l}-0.184 * \\
(0.0974)\end{array}$ & $\begin{array}{c}-0.253^{* *} \\
(0.105)\end{array}$ & $\begin{array}{c}-0.184^{*} \\
(0.0972)\end{array}$ & $\begin{array}{c}-0.268 * * \\
(0.108)\end{array}$ & $\begin{array}{l}-0.158 * \\
(0.0934)\end{array}$ & $\begin{array}{l}-0.194 \\
(0.123)\end{array}$ & $\begin{array}{l}-0.157 * \\
(0.0932)\end{array}$ & $\begin{array}{c}-0.206 \\
(0.126)\end{array}$ \\
\hline Moderate intellectual similarity (vs. High) & $\begin{array}{l}-0.105^{*} \\
(0.0532)\end{array}$ & $\begin{array}{c}-0.166^{* * *} \\
(0.0601)\end{array}$ & $\begin{array}{l}-0.104 * \\
(0.0531)\end{array}$ & $\begin{array}{c}0.0939 \\
(0.0579)\end{array}$ & $\begin{array}{l}-0.0969 * \\
(0.0546)\end{array}$ & $\begin{array}{c}0.0335 \\
(0.0604)\end{array}$ & $\begin{array}{l}-0.0955^{*} \\
(0.0544)\end{array}$ & $\begin{array}{c}0.0356 \\
(0.0617)\end{array}$ \\
\hline Post co-author & $\begin{array}{c}7.530 * * * \\
(1.785)\end{array}$ & & $\begin{array}{c}7.525^{* * *} \\
(1.784)\end{array}$ & & $\begin{array}{c}7.531^{* * *} \\
(1.784)\end{array}$ & & $\begin{array}{c}7.526^{* * *} \\
(1.784)\end{array}$ & \\
\hline Grant co-applicant & $\begin{array}{c}-2.201 \\
(1.381)\end{array}$ & & $\begin{array}{c}-2.184 \\
(1.380)\end{array}$ & & $\begin{array}{c}-2.207 \\
(1.381)\end{array}$ & & $\begin{array}{l}-2.189 \\
(1.380)\end{array}$ & \\
\hline Prior co-author & $\begin{array}{c}6.948 \\
(5.661)\end{array}$ & $\begin{array}{c}10.31 \\
(6.313)\end{array}$ & $\begin{array}{c}6.928 \\
(5.660)\end{array}$ & $\begin{array}{c}10.37 \\
(6.367)\end{array}$ & $\begin{array}{c}6.952 \\
(5.661)\end{array}$ & $\begin{array}{c}10.26 \\
(6.319)\end{array}$ & $\begin{array}{c}6.933 \\
(5.659)\end{array}$ & $\begin{array}{c}10.31 \\
(6.360)\end{array}$ \\
\hline Geographic distance & $\begin{array}{l}-0.00575 \\
(0.00358)\end{array}$ & $\begin{array}{l}-0.00564 \\
(0.00359)\end{array}$ & $\begin{array}{l}-0.00572 \\
(0.00356)\end{array}$ & $\begin{array}{l}-0.00521 \\
(0.00355)\end{array}$ & $\begin{array}{l}-0.00582 \\
(0.00362)\end{array}$ & $\begin{array}{c}-0.00578 \\
(0.00384)\end{array}$ & $\begin{array}{l}-0.00579 \\
(0.00356)\end{array}$ & $\begin{array}{l}-0.00534 \\
(0.00389)\end{array}$ \\
\hline Same institution & $\begin{array}{l}-0.0316 \\
(0.0477)\end{array}$ & $\begin{array}{c}0.0696 \\
(0.0522)\end{array}$ & $\begin{array}{l}-0.0329 \\
(0.0477)\end{array}$ & $\begin{array}{c}0.0756 \\
(0.0521)\end{array}$ & $\begin{array}{l}-0.0322 \\
(0.0477)\end{array}$ & $\begin{array}{c}0.0686 \\
(0.0530)\end{array}$ & $\begin{array}{c}-0.0336 \\
(0.0477)\end{array}$ & $\begin{array}{c}0.0746 \\
(0.0527)\end{array}$ \\
\hline Same department & $\begin{array}{c}0.0487 \\
(0.0877)\end{array}$ & $\begin{array}{l}0.183^{*} \\
(0.102)\end{array}$ & $\begin{array}{c}0.0481 \\
(0.0880)\end{array}$ & $\begin{array}{c}0.208^{*} \\
(0.109)\end{array}$ & $\begin{array}{c}0.0487 \\
(0.0877)\end{array}$ & $\begin{array}{l}0.179 * \\
(0.105)\end{array}$ & $\begin{array}{c}0.0481 \\
(0.0881)\end{array}$ & $\begin{array}{l}0.204^{*} \\
(0.112)\end{array}$ \\
\hline Same imaging modality & $\begin{array}{c}0.0333 \\
(0.0558)\end{array}$ & $\begin{array}{c}0.0634 \\
(0.0629)\end{array}$ & $\begin{array}{c}0.0327 \\
(0.0556)\end{array}$ & $\begin{array}{c}0.0686 \\
(0.0644)\end{array}$ & $\begin{array}{c}0.0342 \\
(0.0557)\end{array}$ & $\begin{array}{c}0.0619 \\
(0.0632)\end{array}$ & $\begin{array}{c}0.0336 \\
(0.0556)\end{array}$ & $\begin{array}{c}0.0670 \\
(0.0651)\end{array}$ \\
\hline Both clinicians & $\begin{array}{c}0.0288 \\
(0.0517)\end{array}$ & $\begin{array}{c}0.0386 \\
(0.0533)\end{array}$ & $\begin{array}{c}0.0288 \\
(0.0518)\end{array}$ & $\begin{array}{c}0.0393 \\
(0.0544)\end{array}$ & $\begin{array}{c}0.0295 \\
(0.0517)\end{array}$ & $\begin{array}{c}0.0396 \\
(0.0531)\end{array}$ & $\begin{array}{c}0.0295 \\
(0.0518)\end{array}$ & $\begin{array}{c}0.0403 \\
(0.0541)\end{array}$ \\
\hline Both imagers & $\begin{array}{c}0.0987 \\
(0.0808)\end{array}$ & $\begin{array}{c}0.108 \\
(0.0830)\end{array}$ & $\begin{array}{c}0.0979 \\
(0.0807)\end{array}$ & $\begin{array}{c}0.0973 \\
(0.0833)\end{array}$ & $\begin{array}{c}0.0988 \\
(0.0808)\end{array}$ & $\begin{array}{c}0.111 \\
(0.0832)\end{array}$ & $\begin{array}{c}0.0980 \\
(0.0808)\end{array}$ & $\begin{array}{c}0.0997 \\
(0.0828)\end{array}$ \\
\hline Same rank & $\begin{array}{c}-0.127^{*} \\
(0.0714)\end{array}$ & $\begin{array}{c}-0.119 \\
(0.0727)\end{array}$ & $\begin{array}{l}-0.129 * \\
(0.0715)\end{array}$ & $\begin{array}{c}-0.116 \\
(0.0720)\end{array}$ & $\begin{array}{l}-0.127 * \\
(0.0715)\end{array}$ & $\begin{array}{l}-0.121^{*} \\
(0.0731)\end{array}$ & $\begin{array}{c}-0.129 * \\
(0.0716)\end{array}$ & $\begin{array}{c}-0.119 \\
(0.0729)\end{array}$ \\
\hline Both females & $\begin{array}{l}-0.0175 \\
(0.0426)\end{array}$ & $\begin{array}{c}-0.0158 \\
(0.0427)\end{array}$ & $\begin{array}{l}-0.0157 \\
(0.0423)\end{array}$ & $\begin{array}{l}-0.0217 \\
(0.0458)\end{array}$ & $\begin{array}{l}-0.0174 \\
(0.0424)\end{array}$ & $\begin{array}{l}-0.0194 \\
(0.0454)\end{array}$ & $\begin{array}{c}-0.0156 \\
(0.0421)\end{array}$ & $\begin{array}{l}-0.0255 \\
(0.0488)\end{array}$ \\
\hline Both males & $\begin{array}{c}0.0449 \\
(0.0487)\end{array}$ & $\begin{array}{c}0.0494 \\
(0.0542)\end{array}$ & $\begin{array}{c}0.0463 \\
(0.0487)\end{array}$ & $\begin{array}{c}0.0510 \\
(0.0543)\end{array}$ & $\begin{array}{c}0.0449 \\
(0.0485)\end{array}$ & $\begin{array}{c}0.0517 \\
(0.0531)\end{array}$ & $\begin{array}{c}0.0463 \\
(0.0485)\end{array}$ & $\begin{array}{c}0.0535 \\
(0.0533)\end{array}$ \\
\hline Super expert & $\begin{array}{c}0.293^{*} \\
(0.150)\end{array}$ & $\begin{array}{c}0.263^{*} \\
(0.158)\end{array}$ & $\begin{array}{c}0.294 * \\
(0.150)\end{array}$ & $\begin{array}{c}0.242 \\
(0.157)\end{array}$ & $\begin{array}{c}0.293 * \\
(0.149)\end{array}$ & $\begin{array}{c}0.268 * \\
(0.160)\end{array}$ & $\begin{array}{c}0.294 * \\
(0.150)\end{array}$ & $\begin{array}{c}0.247 \\
(0.159)\end{array}$ \\
\hline Rank difference & -0.0252 & -0.0267 & -0.0255 & -0.0253 & -0.0249 & -0.0276 & -0.0252 & -0.0262 \\
\hline
\end{tabular}


Prior citations

Prior MeSH keywords

Constant

Night FE

Room FE

Observations

R-squared

\begin{tabular}{cccccccc}
$(0.0193)$ & $(0.0200)$ & $(0.0192)$ & $(0.0195)$ & $(0.0193)$ & $(0.0200)$ & $(0.0192)$ & $(0.0200)$ \\
$4.489 * * *$ & $4.602 * * *$ & $4.489 * * *$ & $4.600^{* * *}$ & $4.489 * * *$ & $4.594 * * *$ & $4.489 * * *$ & $4.591 * * *$ \\
$(0.717)$ & $(0.726)$ & $(0.717)$ & $(0.729)$ & $(0.718)$ & $(0.728)$ & $(0.718)$ & $(0.730)$ \\
$-9.16 \mathrm{e}-05$ & -0.000129 & $-9.12 \mathrm{e}-05$ & -0.000143 & $-9.31 \mathrm{e}-05$ & -0.000127 & $-9.28 \mathrm{e}-05$ & -0.000142 \\
$(0.000144)$ & $(0.000155)$ & $(0.000144)$ & $(0.000158)$ & $(0.000145)$ & $(0.000159)$ & $(0.000145)$ & $(0.000157)$ \\
0.171 & 0.236 & 0.163 & -0.0556 & 0.161 & 0.0218 & 0.152 & -0.0152 \\
$(0.134)$ & $(0.153)$ & $(0.134)$ & $(0.116)$ & $(0.138)$ & $(0.104)$ & $(0.137)$ & $(0.108)$ \\
$\mathrm{Y}$ & $\mathrm{Y}$ & $\mathrm{Y}$ & $\mathrm{Y}$ & $\mathrm{Y}$ & $\mathrm{Y}$ & $\mathrm{Y}$ & $\mathrm{Y}$ \\
$\mathrm{Y}$ & $\mathrm{Y}$ & $\mathrm{Y}$ & $\mathrm{Y}$ & $\mathrm{Y}$ & $\mathrm{Y}$ & $\mathrm{Y}$ & $\mathrm{Y}$ \\
15,817 & 15,817 & 15,817 & 15,817 & 15,817 & 15,817 & 15,817 & 15,817 \\
0.179 & 0.131 & 0.180 & 0.122 & 0.179 & 0.131 & 0.180 & 0.120 \\
\hline
\end{tabular}

Two-way robust standard errors in parentheses

*** $\mathrm{p}<0.01,{ }^{* *} \mathrm{p}<0.05, * \mathrm{p}<0.1$ 